\title{
Total Synthesis of Macquarimicins Using an Intramolecular Diels-Alder Approach Inspired by a Biosynthetic Pathway
}

Ryosuke Munakata, Hironori Katakai, Tatsuo Ueki, Jun Kurosaka, Ken-ichi Takao, Kin-ichi Tadano* Department of Applied Chemistry, Keio University, Hiyoshi, Kohoku-ku, Yokohama 223-8522, Japan

\section{Supporting Information}

\section{Experimental Section}

1.1. Synthesis of Substrates for Stille Coupling Reactions $\quad \ldots \ldots \ldots \ldots \ldots \ldots \ldots$ S2

1.2. Model Study on the Intramolecular Diels-Alder Reaction $\quad \ldots \ldots \ldots \ldots \ldots \ldots$ S17

1.3. Synthesis of 14-17 and Examination of the IMDA reaction $\quad \ldots \ldots \ldots \ldots \ldots \ldots$ S29

1.4. Completion of the Total Synthesis $\quad \ldots \ldots \ldots \ldots \ldots \ldots \ldots \ldots \ldots \ldots \ldots \ldots \ldots \ldots \ldots \ldots$

2. Determination of Stereochemistry

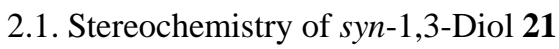
S58

2.2. $\mathrm{C}(2)-\mathrm{C}(3)$ Geometry of TADA Substrates 16 and $49 \quad \ldots \ldots \ldots \ldots \ldots \ldots \ldots \ldots$ S59

2.3. Determination of the Stereochemistry of Cycloadducts $\quad \ldots \ldots \ldots \ldots \ldots \ldots \ldots$ S60

\section{Copies of ${ }^{1} \mathrm{H}$ - and ${ }^{13} \mathrm{C}-\mathrm{NMR}$ Spectra}

3.1. Synthesis of Substrates for Stille Coupling Reactions $\quad \ldots \ldots \ldots \ldots \ldots \ldots \ldots$ S62

3.2. Model Study on the Intramolecular Diels-Alder Reaction $\quad \ldots \ldots \ldots \ldots \ldots \ldots \ldots$ S113

3.3. Synthesis of 14-17 and Examination of the IMDA Reaction $\quad \ldots \ldots \ldots \ldots \ldots$ S145

3.4. Completion of the Total Synthesis $\quad \ldots \ldots \ldots \ldots \ldots \ldots \ldots \ldots \ldots \ldots \ldots \ldots \ldots \ldots \ldots \ldots \ldots$ 


\section{Experimental Section}

\section{General}

Specific rotations were measured in a $10 \mathrm{~mm}$ cell. ${ }^{1} \mathrm{H}$ NMR spectra were recorded at $270 \mathrm{MHz}$ or at 300 $\mathrm{MHz}$ with tetramethylsilane as an internal standard. ${ }^{13} \mathrm{C}$ NMR spectra were recorded at $68 \mathrm{MHz}$ or at $75 \mathrm{MHz}$. All spectra were recorded in $\mathrm{CDCl}_{3}$ as solvent. High-resolution mass spectra (HRMS) were measured by the EI method $(70 \mathrm{eV})$ unless otherwise noted. Thin-layer chromatography (TLC) was performed with a glass plate coated with Kieselgel $60 \mathrm{~F}_{254}$ (Merck). The crude reaction mixtures and extractive materials were purified by chromatography on silica gel Daisogel IR-60 (Daiso Co., Ltd.) or Wakogel C300 (Wako Pure Chemical Industries). Unless otherwise described, reactions were carried out at ambient temperature. Combined organic extracts were dried over anhydrous $\mathrm{Na}_{2} \mathrm{SO}_{4}$. Solvents were removed from reaction mixture or combined organic extracts by concentration under reduced pressure using an evaporator with a water bath at $35-45^{\circ} \mathrm{C}$.

\subsection{Synthesis of Substrates for Stille Coupling Reactions}

\section{$(3 R, 4 S)-4,5-(I s o p r o p y l i d e n e)$ dioxy-3-methyl-1-pentanol ${ }^{1}$}

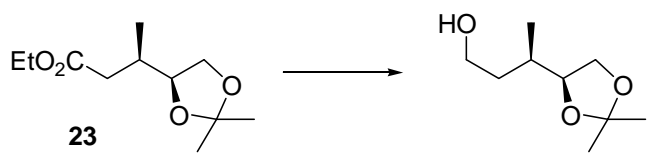

To a cooled $\left(0{ }^{\circ} \mathrm{C}\right)$, stirred solution of $\mathbf{2 3}^{2}(22.9 \mathrm{~g}, 106 \mathrm{mmol})$ in $\mathrm{Et}_{2} \mathrm{O}(230 \mathrm{~mL})$ was added $\mathrm{LiAlH}_{4}(4.02 \mathrm{~g}$, $106 \mathrm{mmol})$. The mixture was stirred at $0{ }^{\circ} \mathrm{C}$ for $1 \mathrm{~h}$ and $\mathrm{LiAlH}_{4}(0.40 \mathrm{~g}, 11 \mathrm{mmol})$ was added. The mixture was stirred at $0{ }^{\circ} \mathrm{C}$ for $0.5 \mathrm{~h}$ and $\mathrm{LiAlH}_{4}(0.80 \mathrm{~g}, 21 \mathrm{mmol})$ was added. The mixture was stirred at $0{ }^{\circ} \mathrm{C}$ for $1 \mathrm{~h}$ and then quenched with $\mathrm{H}_{2} \mathrm{O}(40 \mathrm{~mL})$. This was diluted with an aqueous solution $(350 \mathrm{~mL})$ of potassium sodium (+)-tartrate tetrahydrate $(82.5 \mathrm{~g})$ was added. The mixture was stirred vigorously for $2.5 \mathrm{~h}$ and the organic layer was separated. The aqueous layer was extracted with $\mathrm{CH}_{2} \mathrm{Cl}_{2}$. The combined organic layers were dried and concentrated in vacuo. The residue was purified by column chromatography on silica gel (EtOAc/hexane, 1:10 to $1: 2$ ) to provide $18.0 \mathrm{~g}(98 \%)$ of the primary alcohol as a colorless oil ; TLC, $R_{f} 0.21$ (EtOAc/hexane, 1:2); $[\alpha]^{26}{ }_{\mathrm{D}}+19.0\left(c 1.70, \mathrm{CHCl}_{3}\right) ;{ }^{1} \mathrm{H}$ NMR $(270 \mathrm{MHz}) \delta 0.99(\mathrm{~d}, J=6.6 \mathrm{~Hz}, 3 \mathrm{H}), 1.36$, $1.42(2 \mathrm{~s}, 3 \mathrm{H} \times 2), 1.43(\mathrm{~m}, 1 \mathrm{H}), 1.66(\mathrm{~m}, 1 \mathrm{H}), 1.84(\mathrm{~m}, 1 \mathrm{H}), 1.95(\mathrm{br} \mathrm{s}, 1 \mathrm{H}), 3.61-3.80(\mathrm{~m}, 3 \mathrm{H}), 4.01(\mathrm{~m}$,

\footnotetext{
1 This compound had been synthesized by Boeckman et al. in a different route. See: Boeckman, R. K., Jr., Charette, A. B.; Asberom, T.; Johnston, B. H. J. Am. Chem. Soc. 1991, 113, 5337-5353.

${ }^{2}$ Leonard, J.; Mohialdin, S.; Reed, D.; Ryan, G.; Swain, P. A. Tetrahedron 1995, 51, 12843-12858.
} 
$2 \mathrm{H}) ;{ }^{13} \mathrm{C}$ NMR (75 MHz) $\delta 15.12,25.28,26.38,32.70,35.53,60.30,67.13,79.62,108.73$; IR (neat) 3400, $2990 \mathrm{~cm}^{-1}$; HRMS calcd for $\mathrm{C}_{8} \mathrm{H}_{15} \mathrm{O}_{3}\left(\mathrm{M}^{+}-\mathrm{CH}_{3}\right) \mathrm{m} / 2$ 159.1021, found 159.1024 .

\section{Ethyl (2E,5R,6S)-6,7-(isopropylidene)dioxy-5-methyl-2-heptenoate (24)}

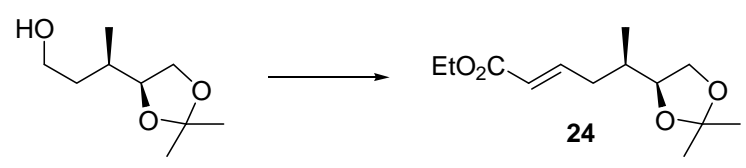

To a cooled $\left(0^{\circ} \mathrm{C}\right)$, stirred solution of alcohol $(18.0 \mathrm{~g}, 103 \mathrm{mmol})$ in $\mathrm{CH}_{2} \mathrm{Cl}_{2}(200 \mathrm{~mL})$ was added Dess-Martin periodinane (52.4 g, $124 \mathrm{mmol})$. The mixture was stirred vigorously for $50 \mathrm{~min}$ and diluted with saturated aqueous $\mathrm{NaHCO}_{3}-10 \%$ aqueous $\mathrm{Na}_{2} \mathrm{~S}_{2} \mathrm{O}_{3}(1: 1,400 \mathrm{~mL})$ and $\mathrm{CH}_{2} \mathrm{Cl}_{2}(200 \mathrm{~mL})$ at $0{ }^{\circ} \mathrm{C}$. The mixture was stirred for $40 \mathrm{~min}$, and the organic layer was separated. The aqueous layer was extracted with $\mathrm{CH}_{2} \mathrm{Cl}_{2}$. The combined organic layers were dried and concentrated in vacuo to give the crude aldehyde, which was used in the next step without purification.

The following reaction was carried out under argon. To a cooled $\left(0{ }^{\circ} \mathrm{C}\right)$, stirred suspension of $\mathrm{NaH}(60 \%$ in oil, $8.24 \mathrm{~g}, 206 \mathrm{mmol})$ in THF $(200 \mathrm{~mL})$ was added $(\mathrm{EtO}){ }_{2} \mathrm{P}(\mathrm{O}) \mathrm{CH}_{2} \mathrm{CO}_{2} \mathrm{Et}(51 \mathrm{~mL}, 260 \mathrm{mmol})$. The mixture was stirred for $1 \mathrm{~h}$ at room temperature, and a solution of the aldehyde obtained above in THF (20 $\mathrm{mL}$ ) was added at $0{ }^{\circ} \mathrm{C}$. The mixture was stirred for $2 \mathrm{~h}$ and quenched with saturated aqueous $\mathrm{NH}_{4} \mathrm{Cl}$. This was diluted with $\mathrm{H}_{2} \mathrm{O}(400 \mathrm{~mL})$ and extracted with $\mathrm{CH}_{2} \mathrm{Cl}_{2}$. The combined organic layers were dried and concentrated in vacuo. The residue was purified by column chromatography on silica gel (EtOAc/hexane, 1:40) to provide $19.1 \mathrm{~g}$ (76\%) of $\mathbf{2 4}$ as a colorless oil ( $0.55 \mathrm{~g}$ of the $Z$-isomer (2\%) was separated from the $E$-isomer 24); TLC, $R_{f} 0.70\left(\right.$ EtOAc/hexane, 1:2); $[\alpha]^{23}{ }_{\mathrm{D}}+5.0\left(c 1.58, \mathrm{CHCl}_{3}\right) ;{ }^{1} \mathrm{H} \mathrm{NMR}(270 \mathrm{MHz}) \delta 0.98(\mathrm{~d}$, $J=6.6 \mathrm{~Hz}, 3 \mathrm{H}), 1.29(\mathrm{t}, J=7.1 \mathrm{~Hz}, 3 \mathrm{H}), 1.35,1.41(2 \mathrm{~s}, 3 \mathrm{H} \times 2), 1.81(\mathrm{~m}, 1 \mathrm{H}), 2.03(\mathrm{~m}, 1 \mathrm{H}), 2.31(\mathrm{~m}, 1 \mathrm{H})$, $3.63(\mathrm{~m}, 1 \mathrm{H}), 3.92-4.04(\mathrm{~m}, 2 \mathrm{H}), 4.19(\mathrm{q}, J=7.1 \mathrm{~Hz}, 2 \mathrm{H}), 5.85(\mathrm{dt}, J=15.4,1.5 \mathrm{~Hz}, 1 \mathrm{H}), 6.92$ (ddd, $J=7.0$, 8.1, $15.4 \mathrm{~Hz}, 1 \mathrm{H}) ;{ }^{13} \mathrm{C}$ NMR $(68 \mathrm{MHz}) \delta 14.22,15.23,25.28,26.40,35.56,35.68,60.21,67.09,79.13$, 108.79, 122.96, 146.89, 166.36; IR (neat) 2990, 1715, $1650 \mathrm{~cm}^{-1}$; HRMS calcd for $\mathrm{C}_{13} \mathrm{H}_{22} \mathrm{O}_{4}\left(\mathrm{M}^{+}\right) \mathrm{m} / \mathrm{z}$ 242.1518 , found 242.1518 .

\section{(2E,5R,6S)-6,7-(Isopropylidene)dioxy-5-methyl-2-hepten-1-ol}

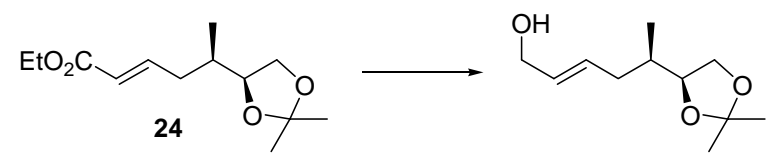

The following reaction was carried out under argon. To a cooled $\left(-78^{\circ} \mathrm{C}\right)$, stirred solution of $24(19.1 \mathrm{~g}, 78.6$ 
mmol) in $\mathrm{CH}_{2} \mathrm{Cl}_{2}(200 \mathrm{~mL})$ was added Dibal-H (195 mL of $1.0 \mathrm{M}$ in toluene, $\left.195 \mathrm{mmol}\right)$. The mixture was stirred at $-78{ }^{\circ} \mathrm{C}$ for $45 \mathrm{~min}$ and quenched with $\mathrm{H}_{2} \mathrm{O}$. This was diluted with $\mathrm{CH}_{2} \mathrm{Cl}_{2}(10 \mathrm{~mL})$, and then an aqueous solution $(400 \mathrm{~mL})$ of potassium sodium $(+)$-tartrate tetrahydrate $(140 \mathrm{~g})$ was added. The mixture was stirred vigorously for $2.5 \mathrm{~h}$ and the organic layer was separated. The aqueous layer was extracted with $\mathrm{CH}_{2} \mathrm{Cl}_{2}$. The combined organic layers were dried and concentrated in vacuo to give crude the primary alcohol, which was used in the next step without purification. In a small-scale experiment, the pure product was obtained by column chromatography on silica gel (EtOAc/hexane, 1:4) as a colorless oil; TLC, $R_{f} 0.29$ (EtOAc/hexane, 1:2); $[\alpha]^{23}{ }_{\mathrm{D}}+8.2\left(c 1.72, \mathrm{CHCl}_{3}\right) ;{ }^{1} \mathrm{H} \mathrm{NMR}(270 \mathrm{MHz}) \delta 0.97(\mathrm{~d}, J=7.0 \mathrm{~Hz}, 3 \mathrm{H}), 1.35,1.40$ $(2 \mathrm{~s}, 3 \mathrm{H} \times 2), 1.69(\mathrm{~m}, 1 \mathrm{H}), 1.80-1.93(\mathrm{~m}, 2 \mathrm{H}), 2.15(\mathrm{~m}, 1 \mathrm{H}), 3.62(\mathrm{t}, J=7.3 \mathrm{~Hz}, 1 \mathrm{H}), 3.92(\mathrm{dt}, J=7.3,6.2$ $\mathrm{Hz}, 1 \mathrm{H}), 4.00(\mathrm{dd}, J=6.2,7.3 \mathrm{~Hz}, 1 \mathrm{H}), 4.10(\mathrm{~m}, 2 \mathrm{H}), 5.62-5.69(\mathrm{~m}, 2 \mathrm{H}) ;{ }^{13} \mathrm{C} \mathrm{NMR}(68 \mathrm{MHz}) \delta 15.38,25.43$, 26.49, 35.62, 36.34, 63.44, 67.44, 79.59, 108.56, 130.36, 130.91; IR (neat) 3400, $2990 \mathrm{~cm}^{-1}$; HRMS calcd for $\mathrm{C}_{11} \mathrm{H}_{20} \mathrm{O}_{3}\left(\mathbf{M}^{+}\right) m / z$ 200.1412, found 200.1401.

\section{$(2 S, 3 R, 5 E)-3-M e t h y l-5-h e p t e n e-1,2,7-t r i o l ~(25)$}

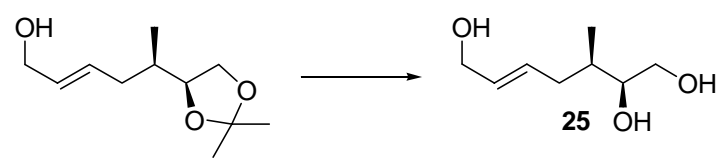

To a cooled $\left(0{ }^{\circ} \mathrm{C}\right)$, stirred solution of the crude primary alcohol obtained above in $\mathrm{MeOH}-\mathrm{H}_{2} \mathrm{O}(1: 1,300$ $\mathrm{mL}$ ) was added Amberlyst 15 (3.15 g). The mixture was stirred at $50{ }^{\circ} \mathrm{C}$ for $12 \mathrm{~h}$ and then the resin was filtered off. The filtrate was concentrated in vacuo to give crude $\mathbf{2 5}$, which was used in the next step without purification. In a small-scale experiment, pure 25 was obtained by column chromatography on silica gel (acetone/toluene, 1:3) as a colorless oil; TLC, $R_{f} 0.22$ (acetone/toluene, $\left.1: 1\right) ;[\alpha]^{22}{ }_{\mathrm{D}}+0.80(c 1.32, \mathrm{MeOH}) ;{ }^{1} \mathrm{H}$ $\operatorname{NMR}(270 \mathrm{MHz}) \delta 0.94(\mathrm{~d}, J=6.6 \mathrm{~Hz}, 3 \mathrm{H}), 1.68(\mathrm{~m}, 1 \mathrm{H}), 1.78(\mathrm{br} \mathrm{s}, 3 \mathrm{H}), 1.97(\mathrm{~m}, 1 \mathrm{H}), 2.23(\mathrm{~m}, 1 \mathrm{H})$, 3.53-3.70 (m, 3H), 4.10-4.12 (m, 2H), 5.66-5.72 (m, 2H); ${ }^{13} \mathrm{C}$ NMR (68 MHz) $\delta 14.37,35.56,36.08,63.58$, 65.05, 74.81, 130.85, 130.94; IR (neat) 3350, $2930 \mathrm{~cm}^{-1}$; HRMS calcd for $\mathrm{C}_{8} \mathrm{H}_{14} \mathrm{O}_{2}\left(\mathrm{M}^{+}-\mathrm{H}_{2} \mathrm{O}\right) \mathrm{m} / \mathrm{z} .142 .0994$, found 142.0993 .

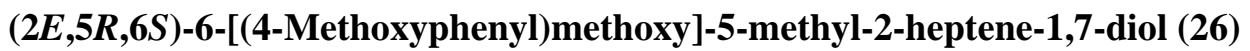

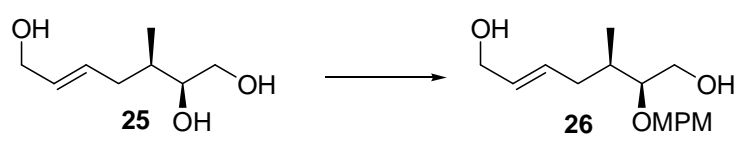

To a cooled $\left(0{ }^{\circ} \mathrm{C}\right)$, stirred solution of the crude $\mathbf{2 5}$ obtained above in DMF $(130 \mathrm{~mL})$ were added 
4-methoxybenzaldehyde dimethylacetal $(16 \mathrm{~mL}, 94 \mathrm{mmol})$ and $\mathrm{TsOH} \cdot \mathrm{H}_{2} \mathrm{O}(748 \mathrm{mg}, 3.93 \mathrm{mmol})$. The mixture was stirred at $50{ }^{\circ} \mathrm{C}$ for $3 \mathrm{~h}$ under reduced pressure with aspirator and then 4-methoxybenzaldehyde dimethylacetal $(2.7 \mathrm{~mL}, 16 \mathrm{mmol})$ was added. The mixture was stirred at $50{ }^{\circ} \mathrm{C}$ for $14 \mathrm{~h}$ under reduced pressure. This was diluted with saturated aqueous $\mathrm{NaHCO}_{3}(400 \mathrm{~mL})$ and extracted with EtOAc. The combined organic layers were dried and concentrated in vacuo. The residue was purified by column chromatography on silica gel (EtOAc/hexane, 1:5 to 1:2.5) to provide $18.9 \mathrm{~g}$ of the 4-methoxybenzylidene acetal, which was used immediately in the next step.

The following reaction was carried out under argon. To a cooled $\left(-78{ }^{\circ} \mathrm{C}\right)$, stirred solution of the acetal obtained above (18.9 g) in $\mathrm{CH}_{2} \mathrm{Cl}_{2}(200 \mathrm{~mL})$ was added Dibal-H (202 $\mathrm{mL}$ of $1.0 \mathrm{M}$ in toluene, $\left.202 \mathrm{mmol}\right)$. The mixture was stirred at $-78{ }^{\circ} \mathrm{C}$ for $1.5 \mathrm{~h}$ and then Dibal- $\mathrm{H}(27 \mathrm{~mL}$ of $1.0 \mathrm{M}$ in toluene, $27 \mathrm{mmol})$ was added. The mixture was stirred at $-78{ }^{\circ} \mathrm{C}$ for $3 \mathrm{~h}$ and quenched with $\mathrm{H}_{2} \mathrm{O}$. This was diluted with $\mathrm{CH}_{2} \mathrm{Cl}_{2}(300$ $\mathrm{mL})$, and then an aqueous solution $(500 \mathrm{~mL})$ of potassium sodium $(+)$-tartrate tetrahydrate $(163 \mathrm{~g})$ was added. The mixture was stirred vigorously for $15 \mathrm{~h}$ and the organic layer was separated. The aqueous layer was extracted with $\mathrm{CH}_{2} \mathrm{Cl}_{2}$. The combined organic layers were dried and concentrated in vacuo. The residue was

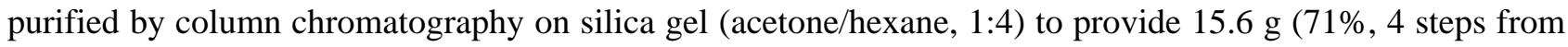
24) of 26 as a colorless oil; TLC, $R_{f} 0.50$ (acetone/toluene, $\left.1: 1\right)$; $[\alpha]^{22}{ }_{\mathrm{D}}+3.1\left(c 1.50, \mathrm{CHCl}_{3}\right) ;{ }^{1} \mathrm{H}$ NMR $(270$ MHz) $\delta 0.94(\mathrm{~d}, J=6.2 \mathrm{~Hz}, 3 \mathrm{H}), 1.80-1.91(\mathrm{~m}, 4 \mathrm{H}), 2.28(\mathrm{~m}, 1 \mathrm{H}), 3.39(\mathrm{~m}, 1 \mathrm{H}), 3.60(\mathrm{dd}, J=6.2,11.4 \mathrm{~Hz}$, $1 \mathrm{H}), 3.67(\mathrm{dd}, J=4.2,11.4 \mathrm{~Hz}, 1 \mathrm{H}), 3.81(\mathrm{~s}, 3 \mathrm{H}), 4.07(\mathrm{~m}, 2 \mathrm{H}), 4.49,4.56(2 \mathrm{~d}, J=11.2 \mathrm{~Hz}, 1 \mathrm{H} \times 2)$, 5.55-5.70 (m, 2H), $6.89(\mathrm{~m}, 2 \mathrm{H}), 7.27(\mathrm{~m}, 2 \mathrm{H}) ;{ }^{13} \mathrm{C}$ NMR (68 MHz) $\delta 15.26,34.32,35.33,55.26,62.03$, $63.55,72.13,82.82,113.86 \times 2,129.35 \times 2,130.56,130.65,131.20,159.24$; IR (neat) 3350, 2940, 1615, $1515 \mathrm{~cm}^{-1}$; HRMS calcd for $\mathrm{C}_{16} \mathrm{H}_{24} \mathrm{O}_{4}\left(\mathrm{M}^{+}\right) \mathrm{m} / 2,280.1675$, found 280.1677 .

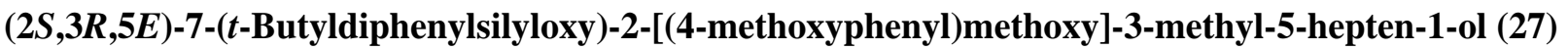

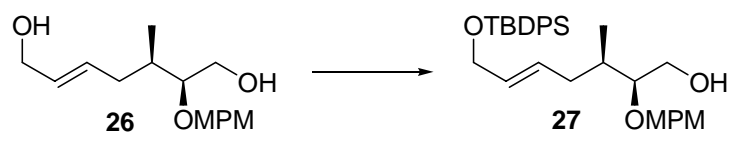

The following reaction was carried out under argon. To a cooled $\left(-78{ }^{\circ} \mathrm{C}\right)$, stirred solution of $26(1.31 \mathrm{~g}, 4.69$ mmol) in $\mathrm{CH}_{2} \mathrm{Cl}_{2}(40 \mathrm{~mL})$ were added $\mathrm{Et}_{3} \mathrm{~N}(1.1 \mathrm{~mL}, 8.0 \mathrm{mmol})$, TBDPSCl $(1.0 \mathrm{~mL}, 4.0 \mathrm{mmol})$, and a solution of DMAP $(57.3 \mathrm{mg}, 0.469 \mathrm{mmol})$ in $\mathrm{CH}_{2} \mathrm{Cl}_{2}(1 \mathrm{~mL})$. The mixture was stirred while gradually wamred to $-20{ }^{\circ} \mathrm{C}$ over $2 \mathrm{~h}$ and then quenched with saturated aqueous $\mathrm{NaHCO}_{3}$. This was diluted with saturated aqueous $\mathrm{NaHCO}_{3}(50 \mathrm{~mL})$ and extracted with $\mathrm{CH}_{2} \mathrm{Cl}_{2}$. The combined organic layers were dried and concentrated in vacuo. The residue was purified by column chromatography on silica gel (EtOAc/hexane, 1:7) to provide $1.77 \mathrm{~g} \mathrm{(73 \% )} \mathrm{of} \mathbf{2 7}$ as a colorless oil along with $0.18 \mathrm{~g}$ of recovered $\mathbf{2 6}$ (13\%); TLC, $R_{f} 0.43$ (EtOAc/hexane, 1:2); $[\alpha]^{21}{ }_{\mathrm{D}}+0.8\left(c 1.89, \mathrm{CHCl}_{3}\right) ;{ }^{1} \mathrm{H} \mathrm{NMR}(270 \mathrm{MHz}) \delta 0.94(\mathrm{~d}, J=6.6 \mathrm{~Hz}, 3 \mathrm{H}), 1.06(\mathrm{~s}$, 
9H), 1.63 (br s, 1H), $1.85(\mathrm{~m}, 2 \mathrm{H}), 2.27(\mathrm{~m}, 1 \mathrm{H}), 3.39$ (ddd, $J=4.0,4.5,6.3 \mathrm{~Hz}, 1 \mathrm{H}), 3.59$ (dd, $J=6.3,11.5$ $\mathrm{Hz}, 1 \mathrm{H}), 3.67(\mathrm{dd}, J=4.0,11.5 \mathrm{~Hz}, 1 \mathrm{H}), 3.80(\mathrm{~s}, 3 \mathrm{H}), 4.16(\mathrm{~d}, J=4.0 \mathrm{~Hz}, 2 \mathrm{H}), 4.47,4.56(2 \mathrm{~d}, J=11.0 \mathrm{~Hz}$, $1 \mathrm{H} \times 2), 5.49-5.65(\mathrm{~m}, 2 \mathrm{H}), 6.88(\mathrm{~m}, 2 \mathrm{H}), 7.33(\mathrm{~m}, 2 \mathrm{H}), 7.42-7.44(\mathrm{~m}, 6 \mathrm{H}), 7.65-7.71(\mathrm{~m}, 4 \mathrm{H}) ;{ }^{13} \mathrm{C} \mathrm{NMR}$ $(68 \mathrm{MHz}) \delta 15.02,19.21,26.81 \times 3,34.47,35.33,55.23,62.17,64.45,72.22,82.96,113.86 \times 2,127.60 \times 4$, $129.18 \times 2,129.35 \times 2,129.55,130.56,130.62,133.82 \times 2,135.52 \times 4,159.21$; IR (neat) $3400,2930,1615$, $1515 \mathrm{~cm}^{-1}$; HRMS calcd for $\mathrm{C}_{28} \mathrm{H}_{33} \mathrm{O}_{4} \mathrm{Si}\left(\mathrm{M}^{+}-t-\mathrm{Bu}\right) \mathrm{m} / z$ 461.2148, found 461.2139 .

(3S,4R,6E)-1,1-Dibromo-8-(t-butyldiphenylsilyloxy)-3-[(4-methoxyphenyl)methoxy]-4-methyl-1,6-octadiene (28)

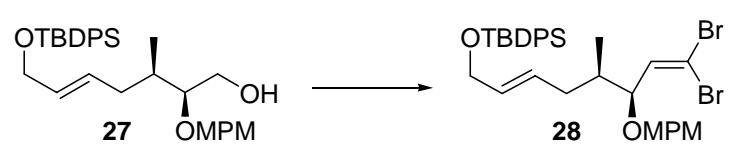

To a cooled $\left(0^{\circ} \mathrm{C}\right)$, stirred solution of $27(10.1 \mathrm{~g}, 19.5 \mathrm{mmol})$ in $\mathrm{CH}_{2} \mathrm{Cl}_{2}(200 \mathrm{~mL})$ was added Dess-Martin periodinane $(10.7 \mathrm{~g}, 25.3 \mathrm{mmol})$. The mixture was stirred vigorously for $1 \mathrm{~h}$ and Dess-Martin periodinane (2.06 $\mathrm{g}, 4.86 \mathrm{mmol}$ ) was added. The mixture was stirred for $1 \mathrm{~h}$ and diluted with saturated aqueous $\mathrm{NaHCO}_{3}-10 \%$ aqueous $\mathrm{Na}_{2} \mathrm{~S}_{2} \mathrm{O}_{3}(1: 1,400 \mathrm{~mL})$ and $\mathrm{CH}_{2} \mathrm{Cl}_{2}(200 \mathrm{~mL})$ at $0{ }^{\circ} \mathrm{C}$. The mixture was stirred for 30 min, and the organic layer was separated. The aqueous layer was extracted with $\mathrm{CH}_{2} \mathrm{Cl}_{2}$. The combined organic layers were dried and concentrated in vacuo to give the crude aldehyde, which was used in the next step without further purification.

The following reaction was carried out under argon. To a cooled $\left(0^{\circ} \mathrm{C}\right)$, stirred solution of $\mathrm{CBr}_{4}(22.6 \mathrm{~g}$, $68.1 \mathrm{mmol})$ in $\mathrm{CH}_{2} \mathrm{Cl}_{2}(100 \mathrm{~mL})$ was added a solution of $\mathrm{PPh}_{3}(35.8 \mathrm{~g}, 136 \mathrm{mmol})$ in $\mathrm{CH}_{2} \mathrm{Cl}_{2}(50 \mathrm{~mL})$. The mixture was stirred at $0{ }^{\circ} \mathrm{C}$ for $10 \mathrm{~min}$ and a solution of the crude aldehyde obtained above in $\mathrm{CH}_{2} \mathrm{Cl}_{2}(50$ $\mathrm{mL}$ ) was added at $-78{ }^{\circ} \mathrm{C}$. The mixture was stirred at $-78{ }^{\circ} \mathrm{C}$ for $1 \mathrm{~h}$ and quenched with saturated aqueous $\mathrm{NaHCO}_{3}$. This was diluted with saturated aqueous $\mathrm{NaHCO}_{3}(500 \mathrm{~mL})$ and extracted with $\mathrm{CH}_{2} \mathrm{Cl}_{2}$. The combined organic layers were dried and concentrated in vacuo. The residue was purified by column chromatography on silica gel (EtOAc/hexane, 1:50) to provide $12.2 \mathrm{~g}$ (93\%) of 28. TLC, $R_{f} 0.74$ (EtOAc/hexane, 1:3); $[\alpha]^{26}{ }_{\mathrm{D}}-2.2\left(c 1.48, \mathrm{CHCl}_{3}\right) ;{ }^{1} \mathrm{H} \mathrm{NMR}(300 \mathrm{MHz}) \delta 0.95(\mathrm{~d}, J=6.6 \mathrm{~Hz}, 3 \mathrm{H}), 1.05(\mathrm{~s}, 9$ H), $1.74(\mathrm{~m}, 1 \mathrm{H}), 1.87(\mathrm{~m}, 1 \mathrm{H}), 2.22(\mathrm{~m}, 1 \mathrm{H}), 3.78(\mathrm{~s}, 3 \mathrm{H}), 3.91(\mathrm{dd}, J=5.6,8.5 \mathrm{~Hz}, 1 \mathrm{H}), 4.14(\mathrm{~d}, J=3.7 \mathrm{~Hz}$, $2 \mathrm{H}), 4.29,4.52(2 \mathrm{~d}, J=11.5 \mathrm{~Hz}, 1 \mathrm{H} \times 2), 5.48-5.66(\mathrm{~m}, 2 \mathrm{H}), 6.44(\mathrm{~d}, J=8.5 \mathrm{~Hz}, 1 \mathrm{H}), 6.87(\mathrm{~m}, 2 \mathrm{H}), 7.25(\mathrm{~m}$, 2H), 7.35-7.41 (m, 6H), 7.64-7.70 (m, 4H); ${ }^{13} \mathrm{C}$ NMR (75 MHz) $\delta 15.00,19.21,26.83 \times 3,35.40,37.77$, $55.22,64.37,70.65,81.84,91.21,113.70 \times 2,127.60 \times 4,128.57,129.44 \times 2,129.56 \times 2,130.28,130.79$, $133.82 \times 2,135.51 \times 4,139.13,159.17$; IR (neat) $3080,2940,1610,1515 \mathrm{~cm}^{-1}$; HRMS calcd for $\mathrm{C}_{29} \mathrm{H}_{31} \mathrm{O}_{3} \mathrm{Br}^{81} \mathrm{BrSi}\left(\mathrm{M}^{+}-t-\mathrm{Bu}\right) \mathrm{m} / \mathrm{z} 615.0389$, found 615.0404 . 

diene (29)

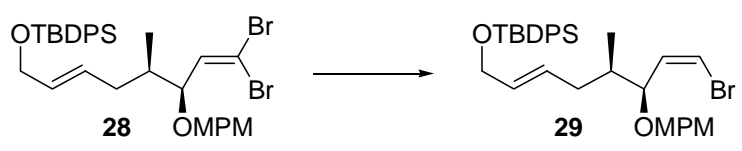

The following reaction was carried out under argon. To a stirred solution of $\mathrm{PPh}_{3}(764 \mathrm{mg}, 2.91 \mathrm{mmol})$ in degassed toluene $(160 \mathrm{~mL})$ was added $\mathrm{Pd}(\mathrm{OAc})_{2}(163 \mathrm{mg}, 0.724 \mathrm{mmol})$. The mixture was stirred for $40 \mathrm{~min}$ and then 28 (12.2 $\mathrm{g}, 18.1 \mathrm{mmol})$ in degassed toluene $(80 \mathrm{~mL})$ and $\mathrm{Bu}_{3} \mathrm{SnH}(5.4 \mathrm{~mL}, 19.9 \mathrm{mmol})$ were added. The mixture was stirred for $30 \mathrm{~min}$ and then diluted with EtOAc $(250 \mathrm{~mL})$. This was washed with saturated brine. The combined aqueous layers were extracted with EtOAc. The combined organic layers were dried and concentrated in vacuo. The residue was purified by column chromatography on silica gel $\left(\mathrm{Et}_{3} \mathrm{~N} / \mathrm{hexane}, 1: 100\right.$ then EtOAc/hexane, 1:70) to provide $9.19 \mathrm{~g}(85 \%)$ of $\mathbf{2 9}$ as a colorless oil; TLC, $\mathrm{R}_{f} 0.68$ (EtOAc/hexane, 1:3); $[\alpha]^{24}{ }_{\mathrm{D}}+3.00\left(c 1.72, \mathrm{CHCl}_{3}\right) ;{ }^{1} \mathrm{H}$ NMR $(270 \mathrm{MHz}) \delta 0.95(\mathrm{~d}, J=6.6 \mathrm{~Hz}, 3 \mathrm{H}), 1.05(\mathrm{~s}, 9 \mathrm{H}), 1.75(\mathrm{~m}, 1 \mathrm{H})$, $1.87(\mathrm{~m}, 1 \mathrm{H}), 2.24(\mathrm{~m}, 1 \mathrm{H}), 3.78(\mathrm{~s}, 3 \mathrm{H}), 4.14(\mathrm{~d}, J=4.4 \mathrm{~Hz}, 2 \mathrm{H}), 4.17(\mathrm{dd}, J=5.9,8.8 \mathrm{~Hz}, 1 \mathrm{H}), 4.28,4.50$ $(2 \mathrm{~d}, J=11.5 \mathrm{~Hz}, 1 \mathrm{H} \times 2), 5.52(\mathrm{dt}, J=15.4,4.4 \mathrm{~Hz}, 1 \mathrm{H}), 5.63(\mathrm{dt}, J=15.4,6.4 \mathrm{~Hz}, 1 \mathrm{H}), 6.14(\mathrm{dd}, J=7.3,8.8$ $\mathrm{Hz}, 1 \mathrm{H}), 6.42(\mathrm{dd}, J=0.7,7.3 \mathrm{~Hz}, 1 \mathrm{H}), 6.86(\mathrm{~m}, 2 \mathrm{H}), 7.26(\mathrm{~m}, 2 \mathrm{H}), 7.36-7.40(\mathrm{~m}, 6 \mathrm{H}), 7.66-7.70(\mathrm{~m}, 4 \mathrm{H})$; ${ }^{13} \mathrm{C}$ NMR $(68 \mathrm{MHz}) \delta 14.94,19.21,26.81 \times 3,35.39,37.78,55.20,64.45,70.38,79.28,110.58,113.63 \times 2$, $127.60 \times 4,128.98,129.41 \times 2,129.53 \times 2,130.53,130.68,133.85 \times 2,135.11,135.52 \times 4,159.04$; IR (neat) 3080, 2940, 1615, $1515 \mathrm{~cm}^{-1}$; HRMS calcd for $\mathrm{C}_{29} \mathrm{H}_{32} \mathrm{O}_{3} \mathrm{Si}^{81} \mathrm{Br}\left(\mathrm{M}^{+}-t-\mathrm{Bu}\right) \mathrm{m} / z$ 537.1284, found 537.1287.

$(1 Z, 3 S, 4 R, 6 E)-8$-( $t$-Butyldiphenylsilyloxy)-3-[(4-methoxyphenyl)methoxy]-4-methyl-1-tributylstannyl-1, 6-octadiene (18)

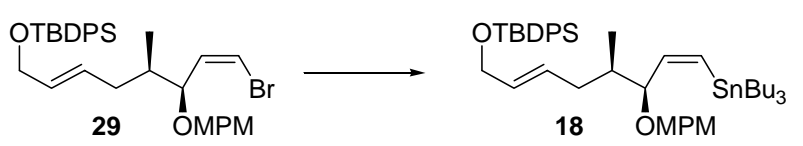

The following reaction was carried out under argon. To a cooled $\left(-78{ }^{\circ} \mathrm{C}\right)$, stirred solution of $29(9.19 \mathrm{~g}, 15.5$ $\mathrm{mmol})$ in $\mathrm{Et}_{2} \mathrm{O}(180 \mathrm{~mL})$ was added $t$-BuLi $(27 \mathrm{~mL}$ of $1.40 \mathrm{M}$ in pentane, $37 \mathrm{mmol})$. The mixture was stirred at $-78{ }^{\circ} \mathrm{C}$ for $1 \mathrm{~h}$ and then $\mathrm{Bu}_{3} \mathrm{SnCl}(5.1 \mathrm{~mL}, 18.6 \mathrm{mmol})$ was added. The mixture was stirred at $-78{ }^{\circ} \mathrm{C}$ for 2 $h$ and then quenched with $\mathrm{H}_{2} \mathrm{O}$. This was diluted with EtOAc $(250 \mathrm{~mL})$, and washed with $\mathrm{H}_{2} \mathrm{O}$. The organic layer was dried and concentrated in vacuo. The residue was purified by column chromatography on silica gel $\left(\mathrm{Et}_{3} \mathrm{~N} /\right.$ hexane, 1:100 then EtOAc/hexane, 1:100) to provide $9.96 \mathrm{~g}(80 \%)$ of $\mathbf{1 8}$ as a colorless oil; TLC, $\mathrm{R}_{f}$ $0.77\left(\right.$ EtOAc/hexane, 1:5); $[\alpha]^{24}{ }_{\mathrm{D}}+5.23\left(c 1.99, \mathrm{CHCl}_{3}\right) ;{ }^{1} \mathrm{H}$ NMR $(300 \mathrm{MHz}) \delta 0.85-0.91(\mathrm{~m}, 15 \mathrm{H}), 0.96(\mathrm{~d}$, 
$J=6.8 \mathrm{~Hz}, 3 \mathrm{H}), 1.05(\mathrm{~s}, 9 \mathrm{H}), 1.25-1.33(\mathrm{~m}, 6 \mathrm{H}), 1.42-1.50(\mathrm{~m}, 6 \mathrm{H}), 1.67(\mathrm{~m}, 1 \mathrm{H}), 1.86(\mathrm{~m}, 1 \mathrm{H}), 2.30(\mathrm{~m}, 1 \mathrm{H})$, $3.45(\mathrm{dd}, J=4.9,8.8 \mathrm{~Hz}, 1 \mathrm{H}), 3.79(\mathrm{~s}, 3 \mathrm{H}), 4.15(\mathrm{~d}, J=3.9 \mathrm{~Hz}, 2 \mathrm{H}), 4.22,4.51(2 \mathrm{~d}, J=11.4 \mathrm{~Hz}, 1 \mathrm{H} \times 2)$, $5.51-5.68(\mathrm{~m}, 2 \mathrm{H}), 6.15\left(\mathrm{~d}, J=13.1,{ }^{2} J_{\mathrm{Sn}-\mathrm{H}}=62.7 \mathrm{~Hz}, 1 \mathrm{H}\right), 6.42(\mathrm{dd}, J=8.8,13.1 \mathrm{~Hz}, 1 \mathrm{H}), 6.86(\mathrm{~m}, 2 \mathrm{H}), 7.24$ $(\mathrm{m}, 2 \mathrm{H}), 7.33-7.42(\mathrm{~m}, 6 \mathrm{H}), 7.66-7.70(\mathrm{~m}, 4 \mathrm{H}) ;{ }^{13} \mathrm{C} \mathrm{NMR}(75 \mathrm{MHz}) \delta 10.51 \times 3,13.68 \times 3,14.59,19.20$, $26.80 \times 3,27.34 \times 3,29.15 \times 3,36.32,38.95,55.24,64.61,69.73,86.15,113.65 \times 2,127.57 \times 4,128.78 \times 2$, $129.52 \times 2,129.95,130.21,131.25,132.81,133.85 \times 2,135.53 \times 4,148.49,158.87$; IR (neat) 3080, 2960, 1615, $1515 \mathrm{~cm}^{-1}$; HRMS calcd for $\mathrm{C}_{41} \mathrm{H}_{59} \mathrm{O}_{3} \mathrm{Si}^{118} \mathrm{Sn}\left(\mathrm{M}^{+}-\mathrm{Bu}\right) \mathrm{m} / \mathrm{z}$ 745.3252, found 745.3241.

\section{(2R)-1-Chloro-5-trimethylsilyl-4-pentyn-2-ol (31) ${ }^{3}$}

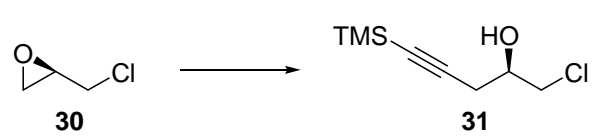

The following reaction was carried out under argon. To a cooled $\left(-78{ }^{\circ} \mathrm{C}\right)$, stirred solution of trimethylsilylacetylene $(5.0 \mathrm{~mL}, 35 \mathrm{mmol})$ in THF $(45 \mathrm{~mL})$ was added $n$-BuLi $(13 \mathrm{~mL}$ of $2.66 \mathrm{M}$ in hexane, $35 \mathrm{mmol}$ ). The mixture was stirred at $-78{ }^{\circ} \mathrm{C}$ for $10 \mathrm{~min}$ and then $(R)$-epichlorohydrin $(\mathbf{3 0})(2.3 \mathrm{~mL}, 30$ mmol) was added. The mixture was stirred at $-78{ }^{\circ} \mathrm{C}$ for $10 \mathrm{~min}$ and then $\mathrm{BF}_{3} \cdot \mathrm{Et}_{2} \mathrm{O}(4.9 \mathrm{~mL}, 35 \mathrm{mmol})$ was added. The mixture was stirred while gradually warmed to $-30{ }^{\circ} \mathrm{C}$ over $2 \mathrm{~h}$ and at $-30{ }^{\circ} \mathrm{C}$ for $19 \mathrm{~h}$. The mixture was quenched with saturated aqueous $\mathrm{NH}_{4} \mathrm{Cl}$. This was diluted with saturated aqueous $\mathrm{NH}_{4} \mathrm{Cl}(200$ $\mathrm{mL}$ ), and extracted with EtOAc. The combined organic layers were dried and concentrated in vacuo to give crude 31, which was used in the next step without purification. In a small-scale experiment, pure $\mathbf{3 1}$ was obtained by column chromatography on silica gel (EtOAc/hexane, 1:20) as a colorless oil; TLC, $\mathrm{R}_{f} 0.60$ (EtOAc/hexane, 1:2); $[\alpha]^{19}{ }_{\mathrm{D}}-10.7\left(c 1.69, \mathrm{CHCl}_{3}\right) ;{ }^{1} \mathrm{H}$ NMR $(270 \mathrm{MHz}) \delta 0.16(\mathrm{~s}, 9 \mathrm{H}), 2.54(\mathrm{dd}, J=6.6$, $16.9 \mathrm{~Hz}, 1 \mathrm{H}), 2.55(\mathrm{~m}, 1 \mathrm{H}), 2.62(\mathrm{dd}, J=5.9,16.9 \mathrm{~Hz}, 1 \mathrm{H}), 3.62(\mathrm{dd}, J=6.0,11.4 \mathrm{~Hz}, 1 \mathrm{H}), 3.72(\mathrm{dd}, J=4.4$, $11.4 \mathrm{~Hz}, 1 \mathrm{H}), 3.98(\mathrm{~m}, 1 \mathrm{H}) ;{ }^{13} \mathrm{C}$ NMR $(68 \mathrm{MHz}) \delta-0.03 \times 3,25.74,48.23,69.60,88.26,101.22$; IR (neat) $3400,2960,2180 \mathrm{~cm}^{-1}$.

(3R)-3-Hydroxy-6-trimethylsilyl-5-hexynenitrile and (3R)-3-Hydroxy-5-hexynenitrile

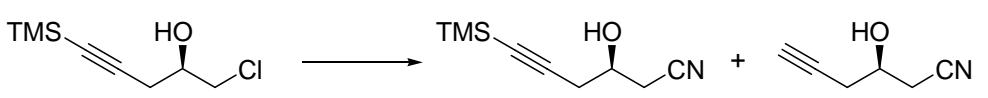

31

To a stirred solution of the crude 31 obtained above in DMSO- $\mathrm{H}_{2} \mathrm{O}(10: 1,44 \mathrm{~mL})$ were added $\mathrm{KCN}$ (2.88 g,

\footnotetext{
3 Takano, S.; Kamikubo, T.; Sugihara, T.; Suzuki, M.; Ogasawara, K. Tetrahedron: Asymmetry 1993, 4, $201-204$.
} 
$44.3 \mathrm{mmol})$ and $\mathrm{NaI}(13.2 \mathrm{~g}, 88.5 \mathrm{mmol})$. The mixture was stirred at $80{ }^{\circ} \mathrm{C}$ for $5 \mathrm{~h}$ and then diluted with EtOAc $(250 \mathrm{~mL})$. This was washed with saturated brine. The combined aqueous layers were extracted with EtOAc. The combined organic layers were dried and concentrated in vacuo to give crude mixture of the nitriles, which were used in the next step without purification. In a small-scale experiment, pure products were obtained by column chromatography on silica gel (EtOAc/hexane, 1:15 to 1:3) as a colorless oil; (3R)-3-Hydroxy-6-trimethylsilyl-5-hexynenitrile: TLC, $\mathrm{R}_{f} 0.30$ (EtOAc/hexane, 1:3); ${ }^{1} \mathrm{H}$ NMR (300 MHz) $\delta$ $0.17(\mathrm{~s}, 9 \mathrm{H}), 2.39$ (d, $J=5.8 \mathrm{~Hz}, 1 \mathrm{H}), 2.59(\mathrm{~d}, J=6.0 \mathrm{~Hz}, 2 \mathrm{H}), 2.66(\mathrm{~m}, 2 \mathrm{H}), 4.11(\mathrm{~m}, 1 \mathrm{H}) ;{ }^{13} \mathrm{C} \mathrm{NMR}(68$ MHz) $\delta-0.12 \times 3,24.73,28.02,66.09,89.56,100.18,117.11$; IR (neat) 3450, 2960, 2250, $2180 \mathrm{~cm}^{-1}$; (3R)-3-Hydroxy-5-hexynenitrile: TLC, $\mathrm{R}_{f} 0.16$ (EtOAc/hexane, 1:3); $[\alpha]^{23}{ }_{\mathrm{D}}-22.0\left(c 2.06, \mathrm{CHCl}_{3}\right) ;{ }^{1} \mathrm{H} \mathrm{NMR}$ $(270 \mathrm{MHz}) \delta 2.15(\mathrm{t}, J=2.6 \mathrm{~Hz}, 1 \mathrm{H}), 2.39(\mathrm{~d}, J=5.5 \mathrm{~Hz}, 1 \mathrm{H}), 2.57(\mathrm{dd}, J=2.6,5.9 \mathrm{~Hz}, 2 \mathrm{H}), 2.65(\mathrm{dd}, J=$ $6.4,16.8 \mathrm{~Hz}, 1 \mathrm{H}), 2.72(\mathrm{dd}, J=5.5,16.8 \mathrm{~Hz}, 1 \mathrm{H}), 4.15(\mathrm{~m}, 1 \mathrm{H}) ;{ }^{13} \mathrm{C}$ NMR $(68 \mathrm{MHz}) \delta 24.62,26.38,65.88$, 72.19, 78.56, 117.32; IR (neat) 3450, 3300, 2920, 2250, $2120 \mathrm{~cm}^{-1}$; HRMS calcd for $\mathrm{C}_{6} \mathrm{H}_{8} \mathrm{NO}\left(\mathrm{M}^{+}+\mathrm{H}\right) \mathrm{m} / \mathrm{z}$ 110.0606, found 110.0628 .

\section{(3R)-3-Hydroxy-5-hexynenitrile}

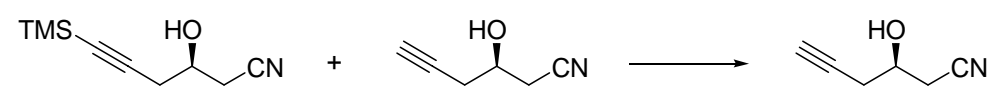

To a cooled $\left(0{ }^{\circ} \mathrm{C}\right)$, stirred solution of the crude mixture obtained above in $\mathrm{MeOH}(26 \mathrm{~mL})$ was added $\mathrm{K}_{2} \mathrm{CO}_{3}$ (395 mg, $2.86 \mathrm{mmol}$ ). The mixture was stirred for $4.5 \mathrm{~h}$ and then Amberlite IR $120\left[\mathrm{H}^{+}\right]$was added at $0{ }^{\circ} \mathrm{C}$ until the $\mathrm{pH}$ of the mixture showed 6 . The resin was filtered off and the filtrate was concentrated in vacuo to give the crude nitrile, which was used in the next step without purification.

\section{(3R)-3-(t-Butyldimethylsilyloxy)-5-hexynenitrile}

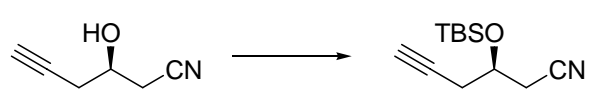

To a cooled $\left(0{ }^{\circ} \mathrm{C}\right)$, stirred solution of the crude (3R)-3-hydroxy-5-hexynenitrile obtained above in DMF (25 $\mathrm{mL})$ were added imidazole $(8.02 \mathrm{~g}, 118 \mathrm{mmol})$ and $\mathrm{TBSCl}(8.92 \mathrm{~g}, 59.2 \mathrm{mmol})$. The mixture was stirred for $13.5 \mathrm{~h}$ and then diluted with $\mathrm{H}_{2} \mathrm{O}(300 \mathrm{~mL})$. This was extracted with $\mathrm{CH}_{2} \mathrm{Cl}_{2}$. The combined organic layers were dried and concentrated in vacuo. The residue was purified by column chromatography on silica gel (EtOAc/hexane, 1:40) to provide $5.62 \mathrm{~g}$ (84\%, 4 steps from 30) of the TBS ether as a colorless oil; TLC, $\mathrm{R}_{f}$ 0.67 (EtOAc/hexane, 1:2); $[\alpha]^{23}{ }_{\mathrm{D}}-16.7\left(\mathrm{c} 2.06, \mathrm{CHCl}_{3}\right) ;{ }^{1} \mathrm{H}$ NMR $(270 \mathrm{MHz}) \delta 0.12,0.15(2 \mathrm{~s}, 3 \mathrm{H} \times 2), 0.91$ (s, 9H), 2.07 (t, $J=2.6 \mathrm{~Hz}, 1 \mathrm{H}), 2.43$ (ddd, $J=2.6,7.3,16.9 \mathrm{~Hz}, 1 \mathrm{H}), 2.51$ (ddd, $J=2.6,5.1,16.9 \mathrm{~Hz}, 1 \mathrm{H}$ ), 
$2.61(\mathrm{dd}, J=6.2,16.5 \mathrm{~Hz}, 1 \mathrm{H}), 2.71(\mathrm{dd}, J=4.4,16.5 \mathrm{~Hz}, 1 \mathrm{H}), 4.09(\mathrm{~m}, 1 \mathrm{H}) ;{ }^{13} \mathrm{C} \mathrm{NMR}(75 \mathrm{MHz}) \delta-4.94$, $-4.79,17.88,25.46,25.56 \times 3,27.11,67.23,71.67,79.09,117.35$; IR (neat) 3300, 2930, 2250, $2120 \mathrm{~cm}^{-1}$; HRMS calcd for $\mathrm{C}_{12} \mathrm{H}_{21} \mathrm{NOSi}\left(\mathrm{M}^{+}\right) \mathrm{m} / z$ 223.1392, found 223.1373.

(3R)-3-(t-Butyldimethylsilyloxy)-5-hexynal (32)

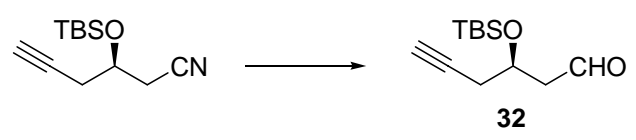

The following reaction was carried out under argon. To a cooled $\left(-52{ }^{\circ} \mathrm{C}\right)$, stirred solution of the nitrile $(5.49$ $\mathrm{g}, 24.6 \mathrm{mmol})$ in toluene $(100 \mathrm{~mL}$ ) was added Dibal-H (35 mL of $1.04 \mathrm{M}$ solution in toluene, $37 \mathrm{mmol})$. The mixture was stirred at $-52{ }^{\circ} \mathrm{C}$ for $2 \mathrm{~h}$ and then quenched with EtOH. This was diluted with $0.2 \mathrm{M}$ aqueous $\mathrm{HCl}(200 \mathrm{~mL})$, and extracted with hexane. The combined organic layers were washed with saturated brine-saturated aqueous $\mathrm{NaHCO}_{3}(1: 1)$. The organic layer was dried and concentrated in vacuo. The residue was purified by column chromatography on silica gel (EtOAc/hexane, 1:40) to provide $5.56 \mathrm{~g}$ (quant.) of 32 as a colorless oil; TLC, $\mathrm{R}_{f} 0.69$ (EtOAc/hexane, 1:5); $[\alpha]^{21}{ }_{\mathrm{D}}-27.1\left(c 1.11, \mathrm{CHCl}_{3}\right) ;{ }^{1} \mathrm{H}$ NMR (270 MHz) $\delta$ $0.08,0.11(2 \mathrm{~s}, 3 \mathrm{H} \times 2), 0.87(\mathrm{~s}, 9 \mathrm{H}), 2.04(\mathrm{t}, J=2.8 \mathrm{~Hz}, 1 \mathrm{H}), 2.39$ (ddd, $J=2.8,7.2,16.7 \mathrm{~Hz}, 1 \mathrm{H}), 2.47$ (ddd, $J=2.8,5.0,16.7 \mathrm{~Hz}, 1 \mathrm{H}), 2.67(\mathrm{ddd}, J=2.4,6.8,16.1 \mathrm{~Hz}, 1 \mathrm{H}), 2.77(\mathrm{ddd}, J=1.7,4.6,16.1 \mathrm{~Hz}, 1 \mathrm{H}), 4.36$ $(\mathrm{m}, 1 \mathrm{H}), 9.82(\mathrm{dd}, J=1.7,2.4 \mathrm{~Hz}, 1 \mathrm{H}) ;{ }^{13} \mathrm{C} \mathrm{NMR}(68 \mathrm{MHz}) \delta-4.93,-4.55,17.91,25.63 \times 3,27.64,50.19$, 66.66, 71.10, 80.17, 201.23; IR (neat) 3300, 2930, 2120, $1730 \mathrm{~cm}^{-1}$; HRMS calcd for $\mathrm{C}_{8} \mathrm{H}_{13} \mathrm{O}_{2} \mathrm{Si}\left(\mathrm{M}^{+}-t-\mathrm{Bu}\right)$ $\mathrm{m} / \mathrm{z}$ 169.0685, found 169.0685 .

$(2 R S, 4 R)-4-(t-B u t y l d i m e t h y l s i l y l o x y)-1-(2,2-d i m e t h y l-1,3-d i o x i n-4-o n e-6-y l)-6-h e p t y n-2-o l$ (ca. 1:1 diastereomeric mixture)

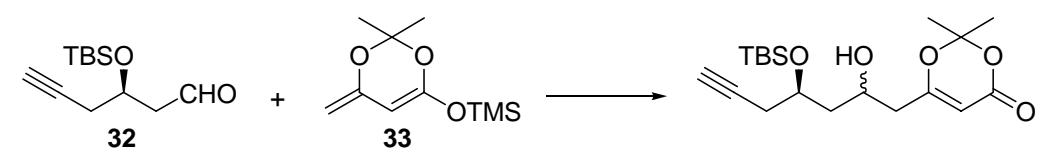

The following reaction was carried out under argon. To a cooled $\left(-78{ }^{\circ} \mathrm{C}\right)$, stirred solution of $32(5.56 \mathrm{~g}, 24.6$ $\mathrm{mmol})$ in $\mathrm{CH}_{2} \mathrm{Cl}_{2}(100 \mathrm{~mL})$ were added $\mathrm{BF}_{3} \cdot \mathrm{Et}_{2} \mathrm{O}(3.3 \mathrm{~mL}, 26 \mathrm{mmol})$ and $\mathbf{3 3}^{4}$ (6.90 g, $\left.32.2 \mathrm{mmol}\right)$. The mixture was stirred at $-78{ }^{\circ} \mathrm{C}$ for $45 \mathrm{~min}$ and then quenched with saturated aqueous $\mathrm{NaHCO}_{3}$. This was diluted with saturated aqueous $\mathrm{NaHCO}_{3}(200 \mathrm{~mL})$, and extracted with $\mathrm{CH}_{2} \mathrm{Cl}_{2}$. The combined organic layers

\footnotetext{
${ }^{4}$ Grunwell, J. R.; Karapides, A.; Wigal, C. T.; Heinzman, S. W.; Parlow, J.; Surso, J. A.; Clayton, L.; Fleitz, F. J.; Daffner, M.; Stevens, J. E. J. Org. Chem. 1991, 56, 91-95.
} 
were dried and concentrated in vacuo. The residue was purified by column chromatography on silica gel (EtOAc/hexane, 1:3) to provide $6.65 \mathrm{~g}(73 \%)$ of the secondary alcohol as a colorless oil; TLC, $\mathrm{R}_{f} 0.28$ (EtOAc/hexane, 1:2); ${ }^{1} \mathrm{H}$ NMR (270 MHz) $\delta 0.12,0.14,0.15$ (3s, total 6H) 0.90, 0.91 (2s, total 9H), 1.70 (s, $6 \mathrm{H}), 1.72-2.04(\mathrm{~m}, 3 \mathrm{H}), 2.30-2.48(\mathrm{~m}, 4 \mathrm{H}), 3.05(\mathrm{~d}, J=2.9 \mathrm{~Hz}, 1 \mathrm{H} \times 1 / 2), 3.20(\mathrm{~d}, J=1.1 \mathrm{~Hz}, 1 \mathrm{H} \times 1 / 2)$, 4.00-4.30 (m, 2H), 5.34, 5.35 (2s, total 1H); IR (neat) 3450, 3300, 2930, 2120, 1735, 1715, $1635 \mathrm{~cm}^{-1}$; HRMS calcd for $\mathrm{C}_{18} \mathrm{H}_{29} \mathrm{O}_{5} \mathrm{Si}\left(\mathrm{M}^{+}-\mathrm{CH}_{3}\right) \mathrm{m} / z$ 353.1784, found 353.1810 .

\section{(4R)-4-(t-Butyldimethylsilyloxy)-1-(2,2-dimethyl-1,3-dioxin-4-one-6-yl)-6-heptyn-2-one}

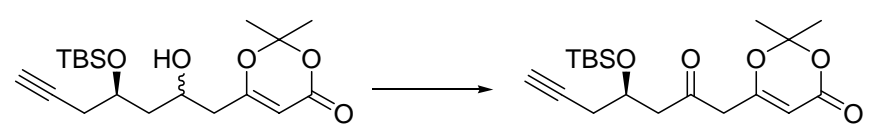

To a cooled $\left(0{ }^{\circ} \mathrm{C}\right)$, stirred solution of $(2 R S, 4 R)$-4-( $t$-butyldimethylsilyloxy)-1-(2,2-dimethyl-1,3-dioxin4-one-6-yl)-6-heptyn-2-ol (12.6 g, $34.1 \mathrm{mmol})$ in $\mathrm{CH}_{2} \mathrm{Cl}_{2}(250 \mathrm{~mL})$ was added Dess-Martin periodinane (17.4 $\mathrm{g}, 40.9 \mathrm{mmol})$. The mixture was stirred for $1.5 \mathrm{~h}$ and then Dess-Martin periodinane $(33.3 \mathrm{~g}, 78.5 \mathrm{mmol})$ was added at $0{ }^{\circ} \mathrm{C}$. The mixture was stirred for $5 \mathrm{~h}$ and then diluted with saturated aqueous $\mathrm{NaHCO}_{3}-20 \%$ aqueous $\mathrm{Na}_{2} \mathrm{~S}_{2} \mathrm{O}_{3}(1: 1,400 \mathrm{~mL})$ and $\mathrm{CH}_{2} \mathrm{Cl}_{2}(200 \mathrm{~mL})$ at $0{ }^{\circ} \mathrm{C}$. The mixture was stirred for $20 \mathrm{~min}$ and then the organic layer was separated. The aqueous layer was extracted with $\mathrm{CH}_{2} \mathrm{Cl}_{2}$. The combined organic layers were dried and concentrated in vacuo to give the crude ketone, which was used in the next step without purification. In a small-scale experiment, the pure ketone was obtained by column chromatography on silica gel (EtOAc/hexane, 1:10) as a colorless oil; TLC, $\mathrm{R}_{f} 0.40$ (EtOAc/hexane, 1:2); $[\alpha]^{21}{ }_{\mathrm{D}}-46.9\left(c 1.56, \mathrm{CHCl}_{3}\right.$ ); ${ }^{1} \mathrm{H}$ NMR $(270 \mathrm{MHz}) \delta 0.05,0.10(2 \mathrm{~s}, 3 \mathrm{H} \times 2), 0.87(\mathrm{~s}, 9 \mathrm{H}), 1.72(\mathrm{~s}, 6 \mathrm{H}), 2.03(\mathrm{t}, J=2.7 \mathrm{~Hz}, 1 \mathrm{H}), 2.34(\mathrm{ddd}, J$ $=2.7,7.0,16.7 \mathrm{~Hz}, 1 \mathrm{H}), 2.42(\mathrm{ddd}, J=2.7,4.8,16.7 \mathrm{~Hz}, 1 \mathrm{H}), 2.78(\mathrm{~m}, 2 \mathrm{H}), 3.34(\mathrm{~d}, J=16.9 \mathrm{~Hz}, 1 \mathrm{H}), 3.41$ $(\mathrm{d}, J=16.9 \mathrm{~Hz}, 1 \mathrm{H}), 4.31(\mathrm{~m}, 1 \mathrm{H}), 5.33(\mathrm{~s}, 1 \mathrm{H}) ;{ }^{13} \mathrm{C} \mathrm{NMR}(68 \mathrm{MHz}) \delta-4.96,-4.73,17.91,24.96,25.05$, $25.68 \times 3,27.36,48.64,49.18,67.24,71.13,80.08,96.73,107.21,160.68,164.25,201.69$; IR (neat) 3300, $2930,2120,1730,1640 \mathrm{~cm}^{-1}$; HRMS calcd for $\mathrm{C}_{15} \mathrm{H}_{21} \mathrm{O}_{5} \mathrm{Si}\left(\mathrm{M}^{+}-t-\mathrm{Bu}\right) \mathrm{m} / z$ 309.1158, found 309.1169.

\section{(4R)-1-(2,2-Dimethyl-1,3-dioxin-4-one-6-yl)-4-hydroxy-6-heptyn-2-one (34)}

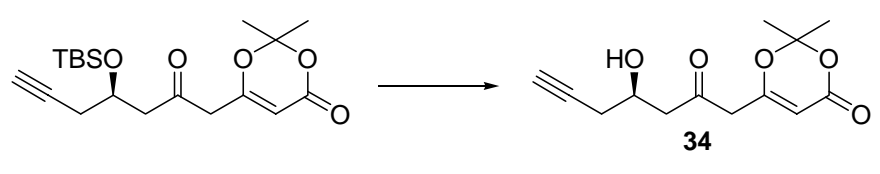

To a cooled $\left(0{ }^{\circ} \mathrm{C}\right)$, stirred solution of the crude ketone obtained above in $\mathrm{MeCN}(250 \mathrm{~mL})$ was added $48 \%$ aq. $\mathrm{HF}(12 \mathrm{~mL})$. The mixture was stirred at room temperature for $8 \mathrm{~h}$ and then quenched with saturated aqueous $\mathrm{NaHCO}_{3}$. This was diluted with saturated aqueous $\mathrm{NaHCO}_{3}(400 \mathrm{~mL})$, and extracted with $\mathrm{CH}_{2} \mathrm{Cl}_{2}$. The 
combined organic layers were dried and concentrated in vacuo. The residue was purified by column chromatography on silica gel (EtOAc/hexane, 1:2) to provide 34 (7.95 g, 92\%, 2 steps) as a colorless oil; TLC, $\mathrm{R}_{f} 0.15$ (EtOAc/hexane, 1:1); $[\alpha]^{22}{ }_{\mathrm{D}}-38.3$ (c 1.21, $\left.\mathrm{CHCl}_{3}\right) ;{ }^{1} \mathrm{H}$ NMR (270 MHz) $\delta 1.72$ (s, 6H), 2.09 (t, $J=2.6 \mathrm{~Hz}, 1 \mathrm{H}), 2.42(\mathrm{ddd}, J=2.6,6.6,16.9 \mathrm{~Hz}, 1 \mathrm{H}), 2.49(\mathrm{ddd}, J=2.6,5.9,16.9 \mathrm{~Hz}, 1 \mathrm{H}), 2.77$ (dd, $J=8.1$, $17.6 \mathrm{~Hz}, 1 \mathrm{H}), 2.87$ (dd, $J=3.7,17.6 \mathrm{~Hz}, 1 \mathrm{H}), 2.93$ (d, $J=4.4 \mathrm{~Hz}, 1 \mathrm{H}), 3.41$ (s, 2H), $4.25(\mathrm{~m}, 1 \mathrm{H}), 5.37$ (s, $1 \mathrm{H}) ;{ }^{13} \mathrm{C}$ NMR $(68 \mathrm{MHz}) \delta 24.96 \times 2,26.26,47.74,48.09,65.77,71.41,79.71,96.87,107.27,160.57,163.82$, 203.16; IR (neat) 3430, 3300, 2920, 2120, 1725, 1715, $1640 \mathrm{~cm}^{-1}$; HRMS calcd for $\mathrm{C}_{13} \mathrm{H}_{17} \mathrm{O}_{5}\left(\mathrm{M}^{+}+\mathrm{H}\right) \mathrm{m} / \mathrm{z}$ 253.1076, found 253.1075 .

\section{(2R,4R)-1-(2,2-Dimethyl-1,3-dioxin-4-one-6-yl)-6-heptyne-2,4-diol (21)}

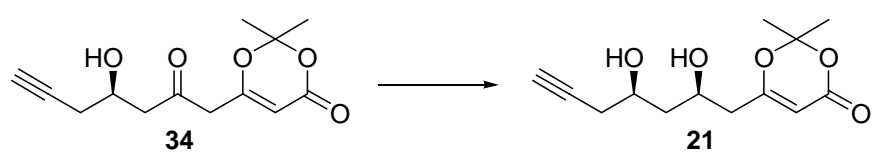

The following reaction was carried out under argon. To a cooled $\left(-78^{\circ} \mathrm{C}\right)$, stirred solution of $\mathbf{3 4}(7.95 \mathrm{~g}, 31.5$ $\mathrm{mmol})$ in THF-MeOH $(150 \mathrm{~mL})$ was added $\mathrm{Et}_{2} \mathrm{BOMe}(38 \mathrm{~mL}$ of $1.0 \mathrm{M}$ solution in THF, $38 \mathrm{mmol})$. The mixture was stirred at $-78{ }^{\circ} \mathrm{C}$ for $30 \mathrm{~min}$ and then $\mathrm{NaBH}_{4}(1.70 \mathrm{~g}, 44.9 \mathrm{mmol})$ was added. The mixture was stirred at $-78{ }^{\circ} \mathrm{C}$ for $8 \mathrm{~h}$. This was quenched with $\mathrm{AcOH}$ and diluted with saturated aqueous $\mathrm{NaHCO}_{3}(300$ $\mathrm{mL}$ ), and extracted with EtOAc. The combined organic layers were dried and concentrated in vacuo. The residue was purified by column chromatography on silica gel (EtOAc/hexane, 2:3) to provide $8.01 \mathrm{~g}$ (quant.) of 21 as a colorless oil; TLC, $\mathrm{R}_{f} 0.10$ (EtOAc/hexane, 1:1); $[\alpha]^{22}{ }_{\mathrm{D}}-14.8\left(c 1.11, \mathrm{CHCl}_{3}\right) ;{ }^{1} \mathrm{H} \mathrm{NMR}(270 \mathrm{MHz})$ $\delta 1.71(\mathrm{~s}, 6 \mathrm{H}), 1.60-1.86(\mathrm{~m}, 2 \mathrm{H}), 2.09(\mathrm{t}, J=2.6 \mathrm{~Hz}, 1 \mathrm{H}), 2.34-2.49(\mathrm{~m}, 4 \mathrm{H}), 3.29$ (br d, $J=10.6 \mathrm{~Hz}, 1 \mathrm{H})$, 3.68 (br d, $J=7.7 \mathrm{~Hz}, 1 \mathrm{H}), 4.05(\mathrm{~m}, 1 \mathrm{H}), 4.18(\mathrm{~m}, 1 \mathrm{H}), 5.35(\mathrm{~s}, 1 \mathrm{H}) ;{ }^{13} \mathrm{C} \mathrm{NMR}(68 \mathrm{MHz}) \delta 24.82,25.20$, 27.79, 41.47, 41.90, 69.00, 70.55, 71.27, 80.05, 95.20, 106.69, 161.26, 168.72; IR (neat) 3410, 3300, 2910, 2120, 1720, $1640 \mathrm{~cm}^{-1}$; HRMS calcd for $\mathrm{C}_{13} \mathrm{H}_{19} \mathrm{O}_{5}\left(\mathrm{M}^{+}+\mathrm{H}\right) \mathrm{m} / \mathrm{z} 255.1233$, found 255.1234.

(2R,4R)-2,4-Bis(t-butyldimethylsilyloxy)-1-(2,2-dimethyl-1,3-dioxin-4-one-6-yl)-6-heptyne

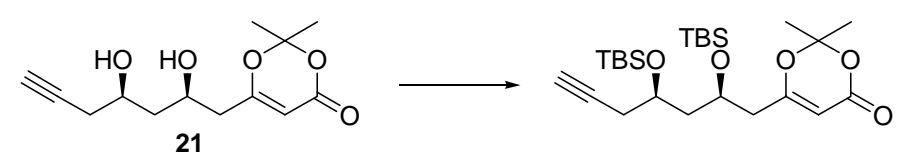

To a cooled $\left(0{ }^{\circ} \mathrm{C}\right)$, stirred solution of $21(4.87 \mathrm{~g}, 19.2 \mathrm{mmol})$ in DMF $(40 \mathrm{~mL})$ were added imidazole $(5.49 \mathrm{~g}$, $80.6 \mathrm{mmol}$ ) and $\mathrm{TBSCl}(6.06 \mathrm{~g}, 40.2 \mathrm{mmol})$. The mixture was stirred for $5 \mathrm{~h}$ and then diluted with saturated aqueous $\mathrm{NaHCO}_{3}(250 \mathrm{~mL})$. This was extracted with $\mathrm{CH}_{2} \mathrm{Cl}_{2}$. The combined organic layers were dried and 
concentrated in vacuo. The residue was purified by column chromatography on silica gel (EtOAc/hexane, 1:10) to provide $8.58 \mathrm{~g}$ (93\%) of the bisTBS ether as a colorless oil; TLC, $\mathrm{R}_{f} 0.48$ (EtOAc/toluene, 1:10); $[\alpha]^{22}{ }_{\mathrm{D}}-40.9\left(c 1.58, \mathrm{CHCl}_{3}\right) ;{ }^{1} \mathrm{H}$ NMR $(270 \mathrm{MHz}) \delta 0.05,0.07,0.09,0.10(4 \mathrm{~s}, 3 \mathrm{H} \times 4), 0.88,0.90(2 \mathrm{~s}, 9 \mathrm{H} \times 2)$, $1.69 \times 2(2 \mathrm{~s}, 3 \mathrm{H} \times 2), 1.79(\mathrm{ddd}, J=5.1,7.7,13.9 \mathrm{~Hz}, 1 \mathrm{H}), 1.88(\mathrm{ddd}, J=4.4,8.1,13.9 \mathrm{~Hz}, 1 \mathrm{H}), 2.00(\mathrm{t}, J=$ $2.6 \mathrm{~Hz}, 1 \mathrm{H}), 2.31(\mathrm{dd}, J=7.3,13.6 \mathrm{~Hz}, 1 \mathrm{H}), 2.34(\mathrm{~m}, 2 \mathrm{H}), 2.44(\mathrm{dd}, J=4.2,13.6 \mathrm{~Hz}, 1 \mathrm{H}), 3.86(\mathrm{~m}, 1 \mathrm{H}), 4.13$ (m, 1H), 5.29 (s, 1H); ${ }^{13} \mathrm{C}$ NMR (68 MHz) $\delta ;-4.73,-4.44,-4.29 \times 2,17.94 \times 2,24.30,25.74 \times 6,25.89,27.70$, 41.58, 44.26, 66.46, 67.93, 70.64, 80.74, 95.66, 106.32, 161.00, 169.12; IR (neat) 3310, 2930, 2120, 1730, $1640 \mathrm{~cm}^{-1}$; HRMS calcd for $\mathrm{C}_{21} \mathrm{H}_{37} \mathrm{O}_{5} \mathrm{Si}_{2}\left(\mathrm{M}^{+}-t-\mathrm{Bu}\right) \mathrm{m} / z$ 425.2180, found 425.2191 .

(2R,4R)-7-Bromo-2,4-bis(t-butyldimethylsilyloxy)-1-(2,2-dimethyl-1,3-dioxin-4-one-6-yl)-6-heptyne (35)

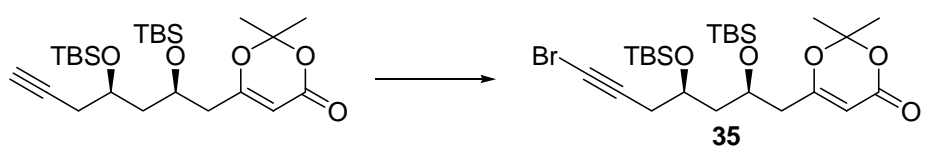

To a cooled $\left(0{ }^{\circ} \mathrm{C}\right)$, stirred solution of the alkyne $(8.58 \mathrm{~g}, 17.8 \mathrm{mmol})$ in acetone $(180 \mathrm{~mL})$ were added $\mathrm{AgNO}_{3}(0.30 \mathrm{~g}, 1.8 \mathrm{mmol})$ and NBS $(3.81 \mathrm{~g}, 21.4 \mathrm{mmol})$. The mixture was stirred at room temperature for 30 min and then diluted with saturated aqueous $\mathrm{NaHCO}_{3}(200 \mathrm{~mL})$. This was extracted with $\mathrm{CH}_{2} \mathrm{Cl}_{2}$. The combined organic layers were dried and concentrated in vacuo. The residue was purified by column chromatography on silica gel (EtOAc/hexane, 1:8) to provide $9.72 \mathrm{~g}(97 \%)$ of $\mathbf{3 5}$ as a colorless oil; TLC, $\mathrm{R}_{f}$ 0.52 (EtOAc/toluene, 1:10); $[\alpha]^{21}{ }_{\mathrm{D}}-36.3\left(c\right.$ 1.38, $\left.\mathrm{CHCl}_{3}\right) ;{ }^{1} \mathrm{H} \mathrm{NMR}(300 \mathrm{MHz}) \delta 0.05,0.08 \times 2,0.10(4 \mathrm{~s}$, $3 \mathrm{H} \times 4), 0.88,0.90(2 \mathrm{~s}, 9 \mathrm{H} \times 2), 1.69,1.70(2 \mathrm{~s}, 3 \mathrm{H} \times 2), 1.80(\mathrm{~m}, 2 \mathrm{H}), 2.32(\mathrm{dd}, J=7.1,13.9 \mathrm{~Hz}, 1 \mathrm{H}), 2.36(\mathrm{~m}$, 2H), $2.44(\mathrm{dd}, J=4.4,13.9 \mathrm{~Hz}, 1 \mathrm{H}), 3.87(\mathrm{~m}, 1 \mathrm{H}), 4.13(\mathrm{~m}, 1 \mathrm{H}), 5.29(\mathrm{~s}, 1 \mathrm{H}) ;{ }^{13} \mathrm{C} \mathrm{NMR}(75 \mathrm{MHz}) \delta-4.77$, $-4.71,-4.49,-4.36,17.91 \times 2,24.28,25.73 \times 6,25.92,28.84,40.28,41.63,44.50,66.42,67.77,76.84,95.65$, 106.35, 160.98, 169.02; IR (neat) 2930, 1730, $1640 \mathrm{~cm}^{-1}$; HRMS calcd for $\mathrm{C}_{21} \mathrm{H}_{36}{ }^{79} \mathrm{BrO}_{5} \mathrm{Si}_{2}\left(\mathrm{M}^{+}-t-\mathrm{Bu}\right) \mathrm{m} / z$ 503.1284 , found 503.1288 .

$(2 R, 4 R, 6 E)-2,4-B i s(t$-butyldimethylsilyloxy)-1-(2,2-dimethyl-1,3-dioxin-4-one-6-yl)-7-iodo-6-heptene (19)

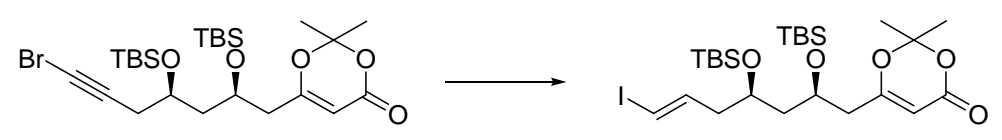

$35 \quad 19$

The following reaction was carried out under argon. To a stirred solution of 35 (9.72 g, $17.3 \mathrm{mmol})$ in argon-bubbled THF $(200 \mathrm{~mL})$ were added $\mathrm{Pd}_{2}(\mathrm{dba})_{3}(79.2 \mathrm{mg}, 0.0865 \mathrm{mmol})$ and $\mathrm{PPh}_{3}(181.5 \mathrm{mg}, 0.692$ 
mmol). Then a solution of $\mathrm{Bu}_{3} \mathrm{SnH}(14 \mathrm{~mL}, 52 \mathrm{mmol})$ in THF $(50 \mathrm{~mL})$ was slowly added over $20 \mathrm{~min}$. The mixture was stirred for $2 \mathrm{~h}$ and then concentrated in vacuo. The residue was dissolved in $\mathrm{CH}_{2} \mathrm{Cl}_{2}(200 \mathrm{~mL})$ and stirred at $0{ }^{\circ} \mathrm{C}$. To the solution $\mathrm{I}_{2}(9.66 \mathrm{~g}, 38.1 \mathrm{mmol})$ was added. The mixture was stirred for $1 \mathrm{~h}$ and then diluted with $10 \%$ aqueous $\mathrm{Na}_{2} \mathrm{~S}_{2} \mathrm{O}_{3}(200 \mathrm{~mL})$. This was extracted with $\mathrm{CH}_{2} \mathrm{Cl}_{2}$. The combined organic layers were dried and concentrated in vacuo. The residue was purified by column chromatography on silica gel (EtOAc/hexane, 1:20) to provide $8.82 \mathrm{~g}$ (84\%) of $\mathbf{1 9}$ as a colorless oil; TLC, $\mathrm{R}_{f} 0.29$ (EtOAc/hexane, 1:5); $[\alpha]^{21}{ }_{\mathrm{D}}-16.4\left(c 1.58, \mathrm{CHCl}_{3}\right) ;{ }^{1} \mathrm{H}$ NMR $(270 \mathrm{MHz}) \delta 0.05,0.06,0.07(3 \mathrm{~s}$, total $12 \mathrm{H}), 0.88,0.90(2 \mathrm{~s}, 9 \mathrm{H} \times 2)$, $1.58(\mathrm{~m}, 1 \mathrm{H}), 1.68,1.70(2 \mathrm{~s}, 3 \mathrm{H} \times 2), 1.73(\mathrm{~m}, 1 \mathrm{H}), 2.21(\mathrm{~m}, 2 \mathrm{H}), 2.30(\mathrm{dd}, J=6.8,13.9 \mathrm{~Hz}, 1 \mathrm{H}), 2.40(\mathrm{dd}, J=$ 4.9, $13.9 \mathrm{~Hz}, 1 \mathrm{H}), 3.79(\mathrm{~m}, 1 \mathrm{H}), 4.05(\mathrm{~m}, 1 \mathrm{H}), 5.27$ (s, 1H), 6.06 (d, J=14.3 Hz, 1H), 6.48 (dt, J= 14.3, 7.4 $\mathrm{Hz}, 1 \mathrm{H}) ;{ }^{13} \mathrm{C}$ NMR $(68 \mathrm{MHz})-4.58 \times 2,-4.44,-4.21,17.94 \times 2,24.42,25.74 \times 3,25.80 \times 3,25.89,41.84$, 43.86, 44.66, 66.49, 67.96, 77.14, 95.66, 106.37, 142.34, 160.91, 168.86; IR (neat) 2930, 1730, $1640 \mathrm{~cm}^{-1}$; HRMS calcd for $\mathrm{C}_{21} \mathrm{H}_{38} \mathrm{O}_{5} \mathrm{Si}_{2} \mathrm{I}\left(\mathrm{M}^{+}-t-\mathrm{Bu}\right) m / z 553.1303$, found 553.1297 .

(6R)-6-[(2R)-2-Hydroxypent-4-yn-1-yl]-4-methoxymethoxy-5,6-dihydropyran-2-one

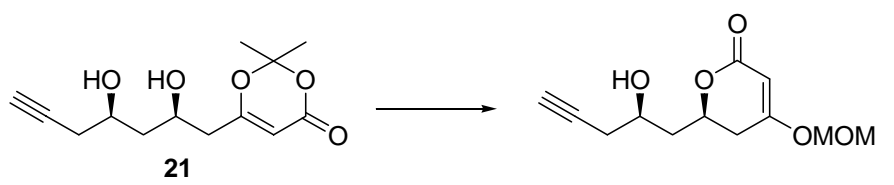

To a cooled $\left(0{ }^{\circ} \mathrm{C}\right)$, stirred solution of $21(155 \mathrm{mg}, 0.608 \mathrm{mmol})$ in $\mathrm{MeOH}(4 \mathrm{~mL})$ were added $\mathrm{Zn}\left(\mathrm{NO}_{3}\right)_{2} \cdot 6 \mathrm{H}_{2} \mathrm{O}(55.8 \mathrm{mg}, 0.188 \mathrm{mmol})$ and $\mathrm{K}_{2} \mathrm{CO}_{3}(129 \mathrm{mg}, 0.936 \mathrm{mmol})$. The mixture was stirred for $93 \mathrm{~h}$ and then $\mathrm{K}_{2} \mathrm{CO}_{3}(43.4 \mathrm{mg}, 0.314 \mathrm{mmol})$ was added. The mixture was stirred for $12 \mathrm{~h}$ and then neutralized with Amberlite IR $120\left[\mathrm{H}^{+}\right]$ion-exchange regin. The mixture was filtered through sintered grass filter and concentrated in vacuo to give the crude lactone which was used in the next step without purification.

To a cooled $\left(-18{ }^{\circ} \mathrm{C}\right)$, stirred solution of the crude product obtained above in $\mathrm{CH}_{2} \mathrm{Cl}_{2}(5 \mathrm{~mL})$ were added $\mathrm{Et}_{3} \mathrm{~N}(0.34 \mathrm{~mL}, 2.43 \mathrm{mmol})$ and chloromethyl methyl ether $(0.092 \mathrm{~mL}, 1.22 \mathrm{mmol})$. The mixture was stirred for $30 \mathrm{~min}$ and then $\mathrm{MeOH}(1 \mathrm{~mL})$ was added. The mixture was diluted with saturated aqueous $\mathrm{NaHCO}_{3}(20$ $\mathrm{mL}$ ), and extracted with $\mathrm{CH}_{2} \mathrm{Cl}_{2}$. The combined organic layers were dried and concentrated in vacuo. The residue was purified by column chromatography on silica gel (EtOAc/hexane, 1:1) to provide $143 \mathrm{mg}(98 \%)$ of the MOM enol ether as a colorless oil; TLC, $\mathrm{R}_{f} 0.45$ (acetone/toluene, 1:1); $[\alpha]^{26}{ }_{\mathrm{D}}-113$ (c 2.09, $\mathrm{CHCl}_{3}$ ); ${ }^{1} \mathrm{H}$ NMR (300 MHz) $\delta 1.95-2.13(\mathrm{~m}, 3 \mathrm{H}), 2.42-2.49$ (m, 3H), $2.63(\mathrm{ddd}, J=1.5,11.7,17.1 \mathrm{~Hz}, 1 \mathrm{H}), 2.79$ (br $\mathrm{s}, 1 \mathrm{H}), 3.48(\mathrm{~s}, 3 \mathrm{H}), 4.05(\mathrm{~m}, 1 \mathrm{H}), 4.66(\mathrm{~m}, 1 \mathrm{H}), 5.09,5.13(2 \mathrm{~d}, J=6.1 \mathrm{~Hz}, 1 \mathrm{H} \times 2), 5.32(\mathrm{~d}, J=1.5 \mathrm{~Hz}, 1 \mathrm{H})$; ${ }^{13} \mathrm{C}$ NMR $(75 \mathrm{MHz}) \delta 27.19,32.50,40.14,57.10,66.77,71.16,74.15,80.17,92.82,94.45,166.77,169.91$; IR (neat) 3400, 3290, 2920, 2120, 1695, 1680, $1625 \mathrm{~cm}^{-1}$; HRMS calcd for $\mathrm{C}_{12} \mathrm{H}_{17} \mathrm{O}_{5}\left(\mathrm{M}^{+}+\mathrm{H}\right) \mathrm{m} / \mathrm{z} .241 .1076$, found 241.1096. 


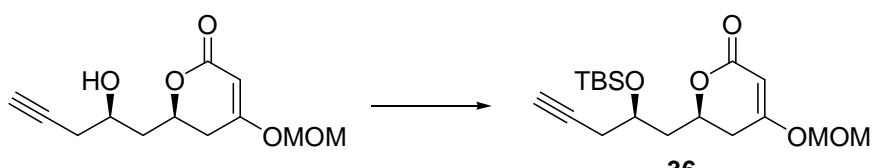

To a cooled $\left(0{ }^{\circ} \mathrm{C}\right)$, stirred solution of the secondary alcohol $(143 \mathrm{mg}, 0.594 \mathrm{mmol})$ in DMF $(1 \mathrm{~mL})$ were added imidazole (165 mg, $2.41 \mathrm{mmol})$ and TBSCl (189 mg, $1.25 \mathrm{mmol})$. The mixture was stirred for $11 \mathrm{~h}$ and then diluted with saturated aqueous $\mathrm{NaHCO}_{3}(20 \mathrm{~mL})$. This was extracted with $\mathrm{CH}_{2} \mathrm{Cl}_{2}$. The combined organic layers were dried and concentrated in vacuo. The residue was purified by column chromatography on silica gel (EtOAc/hexane, 1:3) to provide $188 \mathrm{mg}$ (89\%) of $\mathbf{3 6}$ as a colorless oil; TLC, $\mathrm{R}_{f} 0.34$ (EtOAc/hexane, 1:2); $[\alpha]^{26}{ }_{\mathrm{D}}-93.4\left(c 1.59, \mathrm{CHCl}_{3}\right) ;{ }^{1} \mathrm{H}$ NMR $(270 \mathrm{MHz}) \delta 0.08,0.11(2 \mathrm{~s}, 3 \mathrm{H} \times 2), 0.89(\mathrm{~s}, 9 \mathrm{H}), 1.94-2.03(\mathrm{~m}$, 2H), $2.14(\mathrm{~m}, 1 \mathrm{H}), 2.36-2.45(\mathrm{~m}, 3 \mathrm{H}), 2.55(\mathrm{ddd}, J=1.5,11.4,17.2 \mathrm{~Hz}, 1 \mathrm{H}), 3.47$ (s, 3H), $4.08(\mathrm{~m}, 1 \mathrm{H}), 4.60$ $(\mathrm{m}, 1 \mathrm{H}), 5.08,5.12(2 \mathrm{~d}, J=6.2 \mathrm{~Hz}, 1 \mathrm{H} \times 2), 5.32(\mathrm{~d}, J=1.5 \mathrm{~Hz}, 1 \mathrm{H}) ;{ }^{13} \mathrm{C}$ NMR $(75 \mathrm{MHz}) \delta-4.90,-4.57$, $17.86,25.63 \times 3,26.84,32.83,40.78,56.96,66.95,70.68,72.82,80.42,93.07,94.32,166.75,169.45$; IR (neat) $3300,2930,2120,1715,1635 \mathrm{~cm}^{-1}$; HRMS calcd for $\mathrm{C}_{14} \mathrm{H}_{21} \mathrm{O}_{5} \mathrm{Si}\left(\mathrm{M}^{+}-t-\mathrm{Bu}\right) \mathrm{m} / z z 297.1158$, found 297.1162.

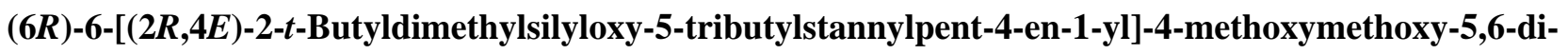
hydropyran-2-one

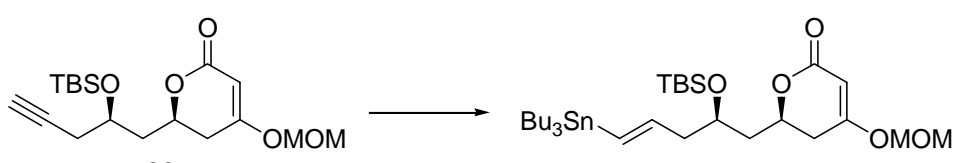

36

The following reaction was carried out under argon. To a stirred solution of $\mathbf{3 6}$ (764 $\mathrm{mg}, 2.91 \mathrm{mmol})$ in benzene $(10 \mathrm{~mL})$ were added $\mathrm{Bu}_{3} \mathrm{SnH}(0.96 \mathrm{~mL}, 3.6 \mathrm{mmol})$ and azobisisobutyronitrile $(14.6 \mathrm{mg}, 0.0890$ $\mathrm{mmol}$ ). The mixture was refluxed for $46 \mathrm{~h}$ and then concentrated in vacuo to give the crude stannylalkene, which was used in the next step without purification. In a small-scale experiment, the pure stannylalkene was obtained by column chromatography on silica gel (EtOAc/hexane, 1:10) as a colorless oil TLC, $\mathrm{R}_{f} 0.67$ (EtOAc/hexane, 1:2); $[\alpha]^{25}{ }_{\mathrm{D}}-48.8\left(c \mathrm{c} 0.945, \mathrm{CHCl}_{3}\right) ;{ }^{1} \mathrm{H}$ NMR $(270 \mathrm{MHz}) \delta 0.06,0.08(2 \mathrm{~s}, 3 \mathrm{H} \times 2), 0.74$ $-0.99(\mathrm{~m}, 24 \mathrm{H}), 1.32(\mathrm{~m}, 6 \mathrm{H}), 1.49(\mathrm{~m}, 6 \mathrm{H}), 1.78(\mathrm{dt}, J=13.9,6.2 \mathrm{~Hz}, 1 \mathrm{H}), 2.04(\mathrm{~m}, 1 \mathrm{H}), 2.26-2.56(\mathrm{~m}, 4 \mathrm{H})$, $3.46(\mathrm{~s}, 3 \mathrm{H}), 4.00(\mathrm{~m}, 1 \mathrm{H}), 4.55(\mathrm{~m}, 1 \mathrm{H}), 5.07,5.11(2 \mathrm{~d}, J=6.2 \mathrm{~Hz}, 1 \mathrm{H} \times 2), 5.32(\mathrm{~d}, J=1.5 \mathrm{~Hz}, 1 \mathrm{H}), 6.46$ $-6.56(\mathrm{~m}, 2 \mathrm{H}) ;{ }^{13} \mathrm{C}$ NMR $(68 \mathrm{MHz}) \delta-4.64,-4.26,9.36 \times 3,13.71 \times 3,18.00,25.80 \times 3,27.27 \times 3,29.11 \times 3$, 33.06, 41.01, 45.41, 57.04, 68.19, 73.23, 93.21, 94.42, 131.71, 144.56, 167.08, 169.58; IR (neat) 2930, 1715, 
$1635 \mathrm{~cm}^{-1}$; HRMS calcd for $\mathrm{C}_{26} \mathrm{H}_{49} \mathrm{O}_{5} \mathrm{SiSn}\left(\mathrm{M}^{+}-\mathrm{Bu}\right) \mathrm{m} / z$ 589.2371, found 589.2373.

(6R)-6-[(2R,4E)-2-t-Butyldimethylsilyloxy-5-iodopent-4-enyl]-4-methoxymethoxy-5,6-dihydropyran-2one (20)

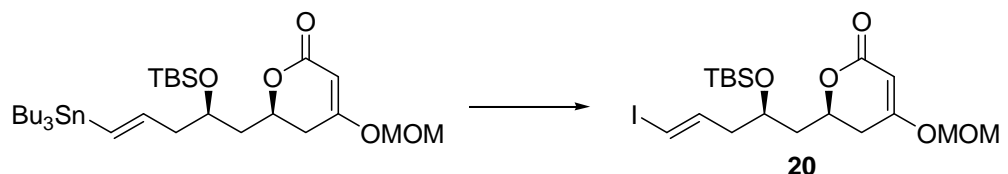

To a cooled $\left(0^{\circ} \mathrm{C}\right)$, stirred solution of the crude stannylalkene obtained above was dissolved in $\mathrm{CH}_{2} \mathrm{Cl}_{2}(10$ $\mathrm{mL}$ ) and stirred at $0{ }^{\circ} \mathrm{C}$. To the solution $\mathrm{I}_{2}(743 \mathrm{mg}, 2.93 \mathrm{mmol})$ was added. The mixture was stirred for 30 min and then diluted with $10 \%$ aqueous $\mathrm{Na}_{2} \mathrm{~S}_{2} \mathrm{O}_{3}(40 \mathrm{~mL})$. This was extracted with $\mathrm{CH}_{2} \mathrm{Cl}_{2}$. The combined organic layers were dried and concentrated in vacuo. The residue was purified by column chromatography on silica gel (EtOAc/hexane, 1:5) to provide $697 \mathrm{mg}(81 \%)$ of $\mathbf{2 0}$ as a colorless oil; TLC, $\mathrm{R}_{f} 0.44$ (EtOAc/hexane, 1:2); $[\alpha]^{24}{ }_{\mathrm{D}}-54.8\left(c 1.95, \mathrm{CHCl}_{3}\right) ;{ }^{1} \mathrm{H}$ NMR $(270 \mathrm{MHz}) \delta 0.06,0.08(2 \mathrm{~s}, 3 \mathrm{H} \times 2), 0.88(\mathrm{~s}, 9 \mathrm{H}), 1.75(\mathrm{~m}, 1 \mathrm{H})$, $2.03(\mathrm{~m}, 1 \mathrm{H}), 2.18-2.39(\mathrm{~m}, 3 \mathrm{H}), 2.52(\mathrm{ddd}, J=1.8,11.4,17.6 \mathrm{~Hz}, 1 \mathrm{H}), 3.47(\mathrm{~s}, 3 \mathrm{H}), 4.01(\mathrm{~m}, 1 \mathrm{H}), 4.52(\mathrm{~m}$, $1 \mathrm{H}), 5.08,5.11(2 \mathrm{~d}, J=6.2 \mathrm{~Hz}, 1 \mathrm{H} \times 2), 5.32(\mathrm{~d}, J=1.8 \mathrm{~Hz}, 1 \mathrm{H}), 6.09(\mathrm{~d}, J=14.3 \mathrm{~Hz}, 1 \mathrm{H}), 6.52$ (ddd $J=$ 7.0, 8.1, 14.3 Hz, 1H); ${ }^{13} \mathrm{C}$ NMR $(75 \mathrm{MHz}) \delta-4.70,-4.41,18.00,25.77 \times 3,33.14,41.41,42.96,57.13$, $67.32,72.68,76.54,93.21,94.48,142.31,166.82,169.50$; IR (neat) 2930, 1715, $1635 \mathrm{~cm}^{-1}$; HRMS calcd for $\mathrm{C}_{18} \mathrm{H}_{32} \mathrm{O}_{5} \mathrm{ISi}\left(\mathrm{M}^{+}+\mathrm{H}\right) \mathrm{m} / z$ 483.1064, found 483.1050. 


\subsection{Model Study on the Intramolecular Diels-Alder Reaction}

\section{Synthesis of $(E, Z, E)-1,6,8-$ nonatriene 38}

The model IMDA substrate $\mathbf{3 8}$ was synthesized as shown in Scheme S1.

\section{Scheme S1.}
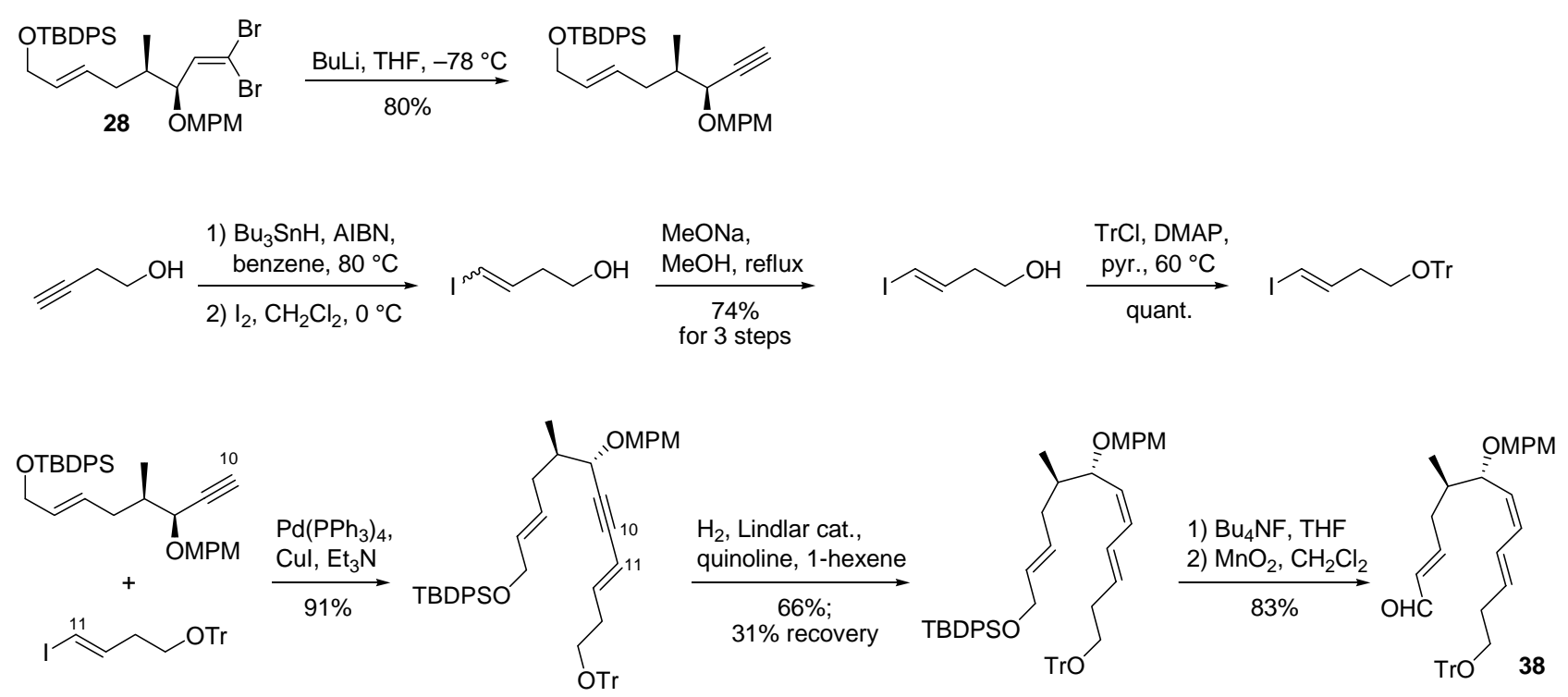

\section{$(3 S, 4 R, 6 E)-8$-(t-Butyldiphenylsilyloxy)-3-[(4-methoxyphenyl)methoxy]-4-methyl-6-octen-1-yne}

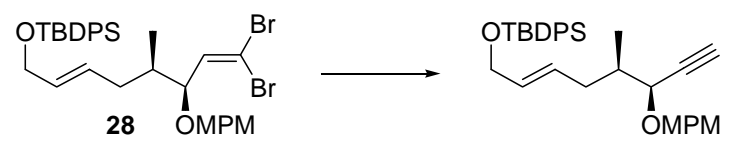

The following reaction was carried out under argon. To a cooled $\left(-78^{\circ} \mathrm{C}\right)$, stirred solution of $28(1.68 \mathrm{~g}, 2.50$ $\mathrm{mmol})$ in THF (30 mL) was added $n$-BuLi $(3.1 \mathrm{~mL}$ of $2.46 \mathrm{M}$ in hexane, $7.5 \mathrm{mmol})$. The mixture was stirred at $-78{ }^{\circ} \mathrm{C}$ for $30 \mathrm{~min}$ and quenched with saturated aqueous $\mathrm{NH}_{4} \mathrm{Cl}$. This was diluted with saturated $\mathrm{NH}_{4} \mathrm{Cl}$ $(100 \mathrm{~mL})$ and extracted with EtOAc. The combined organic layers were dried and concentrated in vacuo. The residue was purified by column chromatography on silica gel (EtOAc/hexane, 1:100) to provide $1.02 \mathrm{~g}(80 \%)$ of the alkyne as a colorless oil; TLC, $R_{f} 0.66$ (EtOAc/hexane, $\left.1: 3\right) ;[\alpha]^{26}{ }_{\mathrm{D}}-50.9\left(c 1.62, \mathrm{CHCl}_{3}\right) ;{ }^{1} \mathrm{H} \mathrm{NMR}$ $(270 \mathrm{MHz}) \delta 0.99(\mathrm{~d}, J=7.0 \mathrm{~Hz}, 3 \mathrm{H}), 1.05(\mathrm{~s}, 9 \mathrm{H}), 1.82(\mathrm{~m}, 1 \mathrm{H}), 1.95(\mathrm{~m}, 1 \mathrm{H}), 2.34(\mathrm{~m}, 1 \mathrm{H}), 2.46(\mathrm{~d}, J=2.0$ $\mathrm{Hz}, 1 \mathrm{H}), 3.78(\mathrm{~s}, 3 \mathrm{H}), 3.93(\mathrm{dd}, J=2.0,4.8 \mathrm{~Hz}, 1 \mathrm{H}), 4.13(\mathrm{~d}, J=4.0 \mathrm{~Hz}, 2 \mathrm{H}), 4.39,4.73(2 \mathrm{~d}, J=11.4 \mathrm{~Hz}, 1 \mathrm{H}$ $\times 2), 5.47-5.65(\mathrm{~m}, 2 \mathrm{H}), 6.85(\mathrm{~m}, 2 \mathrm{H}), 7.28(\mathrm{~m}, 2 \mathrm{H}), 7.36-7.42(\mathrm{~m}, 6 \mathrm{H}), 7.64-7.70(\mathrm{~m}, 4 \mathrm{H}) ;{ }^{13} \mathrm{C}$ NMR $(68$ 
MHz) $\delta 15.09,19.21,26.84 \times 3,35.07,38.24,55.23,64.45,70.26,71.67,74.50,82.07,113.72 \times 2,127.60 \times$ $4,128.81,129.55 \times 2,129.61 \times 2,130.02,130.74,133.87 \times 2,135.52 \times 4,159.19$; IR (neat) 3290, 3070, 2930, 1615, $1515 \mathrm{~cm}^{-1}$; HRMS calcd for $\mathrm{C}_{33} \mathrm{H}_{40} \mathrm{O}_{3} \mathrm{Si}\left(\mathrm{M}^{+}\right) \mathrm{m} / z$ 512.2747, found 512.2742.

\section{(E)-4-Iodo-3-buten-1-ol ${ }^{5}$}

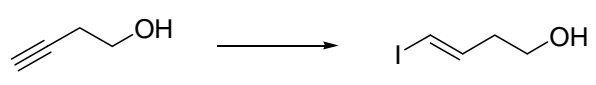

A solution of $\mathrm{Bu}_{3} \mathrm{SnH}$ (4.3 mL, $\left.16 \mathrm{mmol}\right), 2,2$ '-azobisisobutyronitrile (183 mg, $\left.1.11 \mathrm{mmol}\right)$, and 3-butyn-1-ol $(0.74 \mathrm{~g}, 10.6 \mathrm{mmol})$ in benzene $(5 \mathrm{~mL})$ was stirred at $80{ }^{\circ} \mathrm{C}$ for $47 \mathrm{~h}$. After being cooled to ambient temperature, the solution was diluted with $\mathrm{CH}_{2} \mathrm{Cl}_{2}(100 \mathrm{~mL})$. To this solution was added $\mathrm{I}_{2}(4.06 \mathrm{~g}, 16.0$ $\mathrm{mmol})$ at $0{ }^{\circ} \mathrm{C}$. The mixture was stirred at $0{ }^{\circ} \mathrm{C}$ for $30 \mathrm{~min}$ and then washed with $20 \%$ aqueous $\mathrm{Na}_{2} \mathrm{~S}_{2} \mathrm{O}_{3}(50$ $\mathrm{mL}$ ). The organic layer was separated, and the aqueous layer was extracted with $\mathrm{CH}_{2} \mathrm{Cl}_{2}$. The combined organic layers were concentrated in vacuo. The residue was dissolved in $\mathrm{Et}_{2} \mathrm{O}(100 \mathrm{~mL})$ and $10 \%$ aqueous $\mathrm{KF}(50 \mathrm{~mL})$ was added. After being vigorously stirred for $3 \mathrm{~h}$, insoluble precipitates formed were filtered off and washed with $\mathrm{Et}_{2} \mathrm{O}$. From the combined filtrate and washings, the organic layer was separated. The aqueous layer was extracted with $\mathrm{Et}_{2} \mathrm{O}$. The combined organic layers were dried and concentrated in vacuo. The residue was dissolved in $\mathrm{MeOH}(20 \mathrm{~mL})$ and $\mathrm{MeONa}(16 \mathrm{~mL}$ of $1.0 \mathrm{M}$ in $\mathrm{MeOH}, 16 \mathrm{mmol})$ was added. The mixture was heated under reflux for $23 \mathrm{~h}$, and the solvent was removed by evaporation. The residue was diluted with saturated aqueous $\mathrm{NH}_{4} \mathrm{Cl}(100 \mathrm{~mL})$ and extracted with $\mathrm{CH}_{2} \mathrm{Cl}_{2}$. The combined organic layers were dried and concentrated in vacuo. The residue was purified by column chromatography on silica gel (EtOAc/hexane, 1:5) to provide $1.56 \mathrm{~g}(74 \%)$ of the iodoalkene as a colorless oil; TLC, $R_{f} 0.53$ (EtOAc/hexane, 1:2); ${ }^{1} \mathrm{H}$ NMR (300 MHz) $\delta 1.53$ (br s, 1H), 2.33 (ddt, $\left.J=1.4,7.3,6.2 \mathrm{~Hz}, 2 \mathrm{H}\right), 3.69$ (t, $J=$ $6.2 \mathrm{~Hz}, 2 \mathrm{H}), 6.17(\mathrm{dt}, J=14.5 \mathrm{~Hz}, 1.4 \mathrm{~Hz}, 1 \mathrm{H}), 6.55(\mathrm{dt}, J=14.5,7.3 \mathrm{~Hz}, 1 \mathrm{H}) ;{ }^{13} \mathrm{C} \mathrm{NMR}(68 \mathrm{MHz}) \delta 39.05$, 60.85, 77.23, 142.60; IR (neat) 3400, 2950, $1610 \mathrm{~cm}^{-1}$; HRMS calcd for $\mathrm{C}_{4} \mathrm{H}_{7} \mathrm{IO}\left(\mathrm{M}^{+}\right) \mathrm{m} / z$ 197.9542, found 197.9544.

\section{(E)-1-Iodo-4-(triphenylmethoxy)-1-butene}

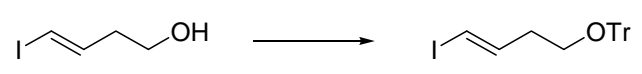

To a cooled $\left(0{ }^{\circ} \mathrm{C}\right)$, stirred solution of the alcohol $(323 \mathrm{mg}, 1.63 \mathrm{mmol})$ in pyridine $(15 \mathrm{~mL})$ were added

\footnotetext{
${ }^{5}$ Chong, J. M.; Heuft, M. A. Tetrahedron 1999, 55, 14243-14250.
} 
chlorotriphenylmethane (546 mg, $1.96 \mathrm{mmol}$ ) and DMAP (38.1 mg, $0.312 \mathrm{mmol})$. The mixture was stirred for $25 \mathrm{~h}$ and then chlorotriphenylmethane $(95.3 \mathrm{mg}, 0.342 \mathrm{mmol}$ ) and DMAP (41.6 mg, $0.342 \mathrm{mmol}$ ) were added. The mixture was stirred for $12 \mathrm{~h}$ at $60{ }^{\circ} \mathrm{C}$ and concentrated in vacuo. The residue was diluted with $\mathrm{NaHCO}_{3}(50 \mathrm{~mL})$ and extracted with $\mathrm{CH}_{2} \mathrm{Cl}_{2}$. The combined organic layers were dried and concentrated in vacuo. The residue was purified by column chromatography on silica gel (EtOAc/hexane, 1:100) to provide $718 \mathrm{mg}(100 \%)$ of the trityl ether as a colorless oil; TLC, $R_{f} 0.48$ (toluene/hexane, $\left.1: 2\right) ;{ }^{1} \mathrm{H}$ NMR (300 MHz) $\delta 2.32(\mathrm{dt}, J=7.1,6.6 \mathrm{~Hz}, 2 \mathrm{H}), 3.11(\mathrm{t}, J=6.6 \mathrm{~Hz}, 2 \mathrm{H}), 6.05(\mathrm{~d}, J=14.4 \mathrm{~Hz}, 1 \mathrm{H}), 6.55(\mathrm{dt}, J=14.4,7.1 \mathrm{~Hz}$, 1H), 7.19-7.32 (m, 9H), 7.41-7.45 (m, 6H); ${ }^{13} \mathrm{C} \mathrm{NMR} \mathrm{(75} \mathrm{MHz)} \delta 36.57,62.13,76.49,86.54,126.94 \times 3$, $127.76 \times 6,128.57 \times 6,143.31,144.00 \times 3$; IR (neat) $3060,2920,1600 \mathrm{~cm}^{-1} ;$ HRMS calcd for $\mathrm{C}_{23} \mathrm{H}_{21} \mathrm{IO}\left(\mathrm{M}^{+}\right)$ $\mathrm{m} / \mathrm{z}$ 440.0637, found 440.0637 .

\section{$(2 E, 5 R, 6 S, 9 E)-1-(t$-Butyldiphenylsilyloxy)-6-[(4-methoxyphenyl)methoxy]-5-methyl-12-(triphenyl- methoxy)-2,9-dodecadien-7-yne}

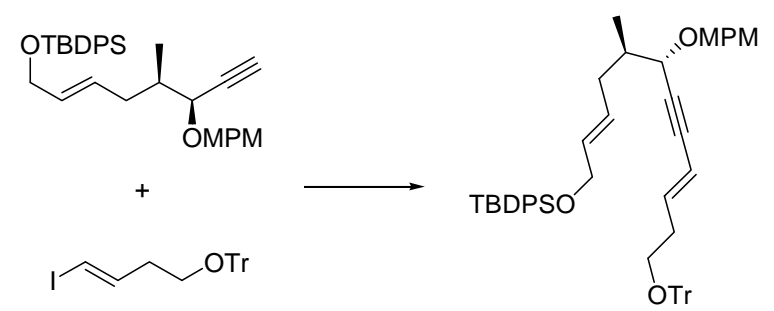

The following reaction was carried out under argon. To a stirred solution of the alkyne $(85.0 \mathrm{mg}, 0.165$ $\mathrm{mmol})$ and the iodoalkene $(87.2 \mathrm{mg}, 0.198 \mathrm{mmol})$ in $\mathrm{Et}_{3} \mathrm{~N}(2 \mathrm{~mL})$ were added $\mathrm{Pd}\left(\mathrm{PPh}_{3}\right)_{4}(9.6 \mathrm{mg}, 8.3 \mu \mathrm{mol})$ and $\mathrm{CuI}(3.6 \mathrm{mg}, 19 \mu \mathrm{mol})$. The mixture was stirred for $2.5 \mathrm{~h}$ and then diluted with saturated aqueous $\mathrm{NaHCO}_{3}(10 \mathrm{~mL})$. This was extracted with $\mathrm{CH}_{2} \mathrm{Cl}_{2}$. The combined organic layers were dried and concentrated in vacuo. The residue was purified by column chromatography on silica gel (EtOAc/hexane, 1:100) to provide $124 \mathrm{mg}$ (91\%) of the coupling product as a colorless oil; TLC, $R_{f} 0.27$ (EtOAc/hexane, 1:20); $[\alpha]^{25}{ }_{\mathrm{D}}-36.8\left(c \mathrm{1.73}, \mathrm{CHCl}_{3}\right) ;{ }^{1} \mathrm{H}$ NMR $(300 \mathrm{MHz}) \delta 0.98(\mathrm{~d}, J=6.6 \mathrm{~Hz}, 3 \mathrm{H}), 1.04(\mathrm{~s}, 9 \mathrm{H}), 1.81(\mathrm{~m}$, $1 \mathrm{H}), 1.96(\mathrm{~m}, 1 \mathrm{H}), 2.30-2.46(\mathrm{~m}, 3 \mathrm{H}), 3.14(\mathrm{t}, J=6.7 \mathrm{~Hz}, 2 \mathrm{H}), 3.76(\mathrm{~s}, 3 \mathrm{H}), 4.02(\mathrm{dd}, J=1.2,4.6 \mathrm{~Hz}, 1 \mathrm{H})$, $4.12(\mathrm{~d}, J=4.1 \mathrm{~Hz}, 2 \mathrm{H}), 4.39,4.71(2 \mathrm{~d}, J=11.5 \mathrm{~Hz}, 1 \mathrm{H} \times 2), 5.47-5.65(\mathrm{~m}, 3 \mathrm{H}), 6.18(\mathrm{dt}, J=15.8,7.1 \mathrm{~Hz}$, $1 \mathrm{H}), 6.83(\mathrm{~m}, 2 \mathrm{H}), 7.22-7.46(\mathrm{~m}, 23 \mathrm{H}), 7.65-7.69(\mathrm{~m}, 4 \mathrm{H}) ;{ }^{13} \mathrm{C} \mathrm{NMR}(75 \mathrm{MHz}) \delta 15.26,19.20,26.81 \times 3$, $33.80,35.22,38.49,55.20,62.74,64.47,70.17,72.41,85.16,86.39,86.56,110.99,113.63 \times 2,126.94 \times 3$, $127.58 \times 4,127.76 \times 6,128.62 \times 6,129.03,129.56 \times 4,130.25,130.56,133.85 \times 2,135.51 \times 4,141.32$, $144.13 \times 3,159.07$; IR (neat) $3040,2935,1615,1515 \mathrm{~cm}^{-1}$; HRMS calcd for $\mathrm{C}_{56} \mathrm{H}_{60} \mathrm{O}_{4} \mathrm{Si}\left(\mathrm{M}^{+}\right) \mathrm{m} / z .824 .4261$, found 824.4244 .

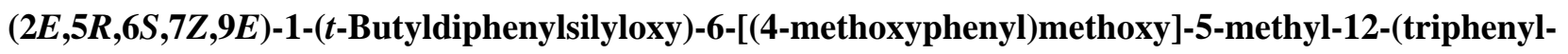


methoxy)-2,7,9-dodecatriene

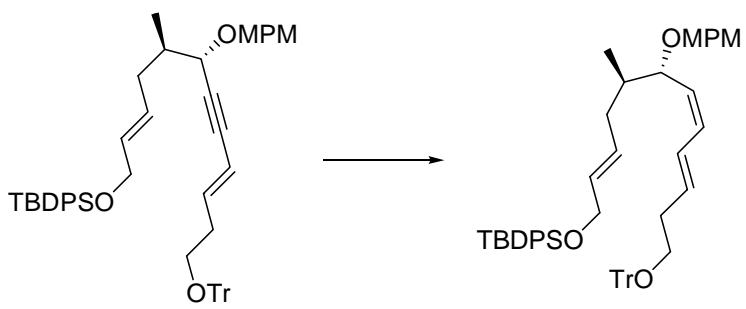

A solution of the alkyne $(58.9 \mathrm{mg}, 0.0714 \mathrm{mmol})$ in 1-hexene $(1 \mathrm{~mL})$ was stirred under atmospheric hydrogen for $2 \mathrm{~h}$ in the presence of Lindlar catalyst $(5.9 \mathrm{mg})$ and quinoline $(0.003 \mathrm{~mL}, 0.03 \mathrm{mmol})$. The catalyst was removed by filtration through a Celite pad, washed with EtOAc and the combined filtrate and washings were concentrated in vacuo. The residue was purified by column chromatography on silica gel (toluene/hexane, $1: 1)$ to provide $38.8 \mathrm{mg}(66 \%)$ of the triene as a colorless oil. $18.3 \mathrm{mg}(31 \%)$ of the starting material was recovered; TLC, $R_{f} \quad 0.28$ (EtOAc/hexane, 1:20); $[\alpha]^{25}{ }_{\mathrm{D}}-4.0\left(c\right.$ 1.66, $\left.\mathrm{CHCl}_{3}\right) ;{ }^{1} \mathrm{H}$ NMR $(270 \mathrm{MHz}) \delta 0.93$ (d, $J=6.2 \mathrm{~Hz}, 3 \mathrm{H}), 1.04(\mathrm{~s}, 9 \mathrm{H}), 1.66-1.79(\mathrm{~m}, 2 \mathrm{H}), 2.24(\mathrm{~m}, 1 \mathrm{H}), 2.37$ (q, $J=6.6 \mathrm{~Hz}, 2 \mathrm{H}), 3.11(\mathrm{t}, J=6.6 \mathrm{~Hz}$, 2H), $3.77(\mathrm{~s}, 3 \mathrm{H}), 3.99(\mathrm{dd}, J=6.2,9.5 \mathrm{~Hz}, 1 \mathrm{H}), 4.12(\mathrm{~d}, J=4.8 \mathrm{~Hz}, 2 \mathrm{H}), 4.20,4.49(2 \mathrm{~d}, J=11.7 \mathrm{~Hz}, 1 \mathrm{H} \times$ 2), $5.27(\mathrm{t}, J=9.5 \mathrm{~Hz}, 1 \mathrm{H}), 5.44-5.65(\mathrm{~m}, 2 \mathrm{H}), 5.75(\mathrm{~m}, 1 \mathrm{H}), 6.18-6.27(\mathrm{~m}, 2 \mathrm{H}), 6.82(\mathrm{~m}, 2 \mathrm{H}), 7.19-7.45(\mathrm{~m}$, 23H) 7.65-7.69 (m, 4H); ${ }^{13} \mathrm{C}$ NMR $(75 \mathrm{MHz}) \delta 15.23,19.20,26.81 \times 3,33.57,35.45,38.46,55.20,63.17$, $64.51,69.56,77.43,86.43,113.57 \times 2,126.89 \times 3,127.20,127.58 \times 4,127.71 \times 6,128.64 \times 6,129.13$, $129.31 \times 2,129.41,129.52 \times 2,130.28,131.02,132.39,133.31,133.85 \times 2,135.50 \times 4,144.21 \times 3,158.92$; IR (neat) 3020, 2930, 1615, $1515 \mathrm{~cm}^{-1}$; HRMS calcd for $\mathrm{C}_{56} \mathrm{H}_{62} \mathrm{O}_{4} \mathrm{Si}\left(\mathrm{M}^{+}\right) \mathrm{m} / z$ 826.4417, found 826.4416.

$(2 E, 5 R, 6 S, 7 Z, 9 E)-6-[(4-M e t h o x y p h e n y l) m e t h o x y]-5-m e t h y l-12$-(triphenylmethoxy)-2,7,9-dodecatrien-1ol

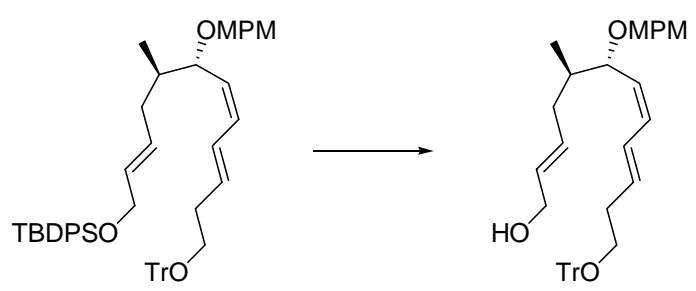

To a cooled $\left(0{ }^{\circ} \mathrm{C}\right)$, stirred solution of the TBDPS ether $(57.5 \mathrm{mg}, 0.0695 \mathrm{mmol})$ in THF $(1 \mathrm{~mL})$ was added tetrabutylammonium fluoride $(0.077 \mathrm{~mL}$ of $1.0 \mathrm{M}$ solution in THF, $0.077 \mathrm{mmol})$. The mixture was stirred for 2.5 h. This was diluted with $\mathrm{H}_{2} \mathrm{O}(10 \mathrm{~mL})$ and extracted with $\mathrm{CH}_{2} \mathrm{Cl}_{2}$. The combined organic layers were dried and concentrated in vacuo. The residue was purified by column chromatography on silica gel (EtOAc/hexane, 1:5) to provide $40.9 \mathrm{mg}$ (quant.) of the primary alcohol as a colorless oil; TLC, $R_{f} \quad 0.37$ 
(EtOAc/hexane, 2:1); $[\alpha]^{24}{ }_{\mathrm{D}}-2.4\left(c 1.67, \mathrm{CHCl}_{3}\right) ;{ }^{1} \mathrm{H}$ NMR $(270 \mathrm{MHz}) \delta 0.93(\mathrm{~d}, J=6.6 \mathrm{~Hz}, 3 \mathrm{H}), 1.48$ (br s, $1 \mathrm{H}), 1.64-1.86(\mathrm{~m}, 2 \mathrm{H}), 2.24(\mathrm{~m}, 1 \mathrm{H}), 2.41(\mathrm{q}, J=6.5 \mathrm{~Hz}, 2 \mathrm{H}), 3.13(\mathrm{t}, J=6.5 \mathrm{~Hz}, 2 \mathrm{H}), 3.78(\mathrm{~s}, 3 \mathrm{H})$, 3.96-4.02 (m, 3H), 4.19, $4.49(2 \mathrm{~d}, J=11.7 \mathrm{~Hz}, 1 \mathrm{H} \times 2), 5.26(\mathrm{t}, J=9.5 \mathrm{~Hz}, 1 \mathrm{H}), 5.50-5.64(\mathrm{~m}, 2 \mathrm{H}), 5.76(\mathrm{~m}$, $1 \mathrm{H}), 6.18-6.32(\mathrm{~m}, 2 \mathrm{H}), 6.83(\mathrm{~m}, 2 \mathrm{H}), 7.19-7.31(\mathrm{~m}, 11 \mathrm{H}), 7.42-7.46(\mathrm{~m}, 6 \mathrm{H}) ;{ }^{13} \mathrm{C} \mathrm{NMR}(68 \mathrm{MHz}) \delta 15.26$, $33.60,35.42,38.30,55.23,63.15,63.73,69.54,77.20,86.45,113.57 \times 2,126.91 \times 3,127.19,127.74 \times 6$, $128.63 \times 6,128.95,129.38 \times 2,130.48,130.94,131.45,132.46,133.41,144.21 \times 3,158.96$; IR (neat) 3400 , 3030, 2930, 1615, $1515 \mathrm{~cm}^{-1}$; HRMS calcd for $\mathrm{C}_{40} \mathrm{H}_{44} \mathrm{O}_{4}\left(\mathrm{M}^{+}\right) \mathrm{m} / \mathrm{z}$ 588.3240, found 588.3243.

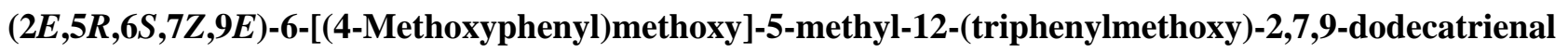
(38)

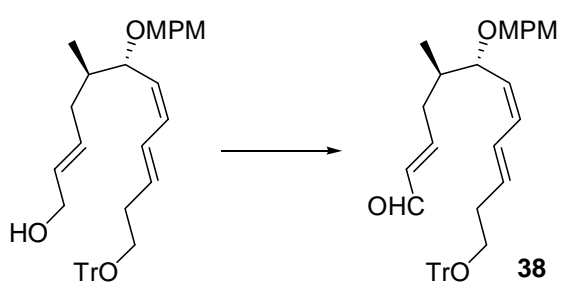

To a cooled $\left(0{ }^{\circ} \mathrm{C}\right)$, stirred solution of the primary alcohol $(38.1 \mathrm{mg}, 0.0647 \mathrm{mmol})$ in $\mathrm{CH}_{2} \mathrm{Cl}_{2}(1 \mathrm{~mL})$ was added $\mathrm{MnO}_{2}$ (411 mg, $4.73 \mathrm{mmol}$ ). The mixture was stirred for $30 \mathrm{~min}$, and the insoluble materials were filtered off and washed well with EtOH. The combined filtrate and washings were concentrated in vacuo. The residue was purified by column chromatography on silica gel (EtOAc/hexane, 1:15) to provide $31.4 \mathrm{mg}$ $(83 \%)$ of $\mathbf{3 8}$ as a colorless oil; $\quad$ TLC, $R_{f} \quad 0.30$ (EtOAc/hexane, 1:5); $[\alpha]^{24}{ }_{\mathrm{D}}-7.9\left(c 1.52, \mathrm{CHCl}_{3}\right) ;{ }^{1} \mathrm{H} \mathrm{NMR}$ $(300 \mathrm{MHz}) \delta 0.95(\mathrm{~d}, J=6.8 \mathrm{~Hz}, 3 \mathrm{H}), 1.88(\mathrm{~m}, 1 \mathrm{H}), 2.07(\mathrm{~m}, 1 \mathrm{H}), 2.41(\mathrm{q}, J=6.6 \mathrm{~Hz}, 2 \mathrm{H}), 2.52(\mathrm{~m}, 1 \mathrm{H})$, $3.14(\mathrm{t}, J=6.6 \mathrm{~Hz}, 2 \mathrm{H}), 3.79(\mathrm{~s}, 3 \mathrm{H}), 4.04(\mathrm{dd}, J=5.9,9.5 \mathrm{~Hz}, 1 \mathrm{H}), 4.19,4.50(2 \mathrm{~d}, J=11.6 \mathrm{~Hz}, 1 \mathrm{H} \times 2)$, $5.26(\mathrm{t}, J=9.5 \mathrm{~Hz}, 1 \mathrm{H}), 5.80(\mathrm{~m}, 1 \mathrm{H}), 6.03(\mathrm{dd}, J=7.9,15.5 \mathrm{~Hz}, 1 \mathrm{H}), 6.20-6.32(\mathrm{~m}, 2 \mathrm{H}), 6.73(\mathrm{~m}, 1 \mathrm{H}), 6.83$ (m, 2H), 7.18-7.31 (m, 11H), 7.42-7.45 (m, 6H), $9.43(\mathrm{~d}, J=7.9 \mathrm{~Hz}, 1 \mathrm{H}) ;{ }^{13} \mathrm{C}$ NMR $(75 \mathrm{MHz}) \delta 15.45$, $33.57,36.04,37.88,55.24,63.03,69.60,76.85,86.46,113.63 \times 2,126.81,126.91 \times 3,127.71 \times 6,127.91$, $128.62 \times 6,129.43 \times 2,130.58,133.18,134.06,134.18,144.18 \times 3,157.87,159.05,193.99$; IR (neat) 3030, 2930, 1690, 1615, $1515 \mathrm{~cm}^{-1}$; HRMS calcd for $\mathrm{C}_{40} \mathrm{H}_{42} \mathrm{O}_{4}\left(\mathrm{M}^{+}\right) \mathrm{m} / \mathrm{z}$ 586.3083, found 586.3066.

Intramolecular Diels-Alder reaction of 38: $(1 S, 2 S, 3 S, 4 Z, 6 S, 7 S, 8 R)$-2-Formyl-7-[(4-methoxyphenyl)methoxy]-8-methyl-3-[2-(triphenylmethoxy)ethyl]bicyclo[4.3.0]non-4-ene (40) 


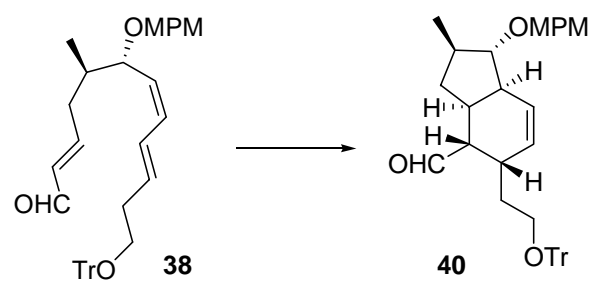

Compound 38 (29.5 mg, $0.0503 \mathrm{mmol})$ was dissolved in degassed toluene $(5 \mathrm{~mL})$, and a crystal of BHT was added. The solution was transferred into a $20 \mathrm{~mL}$ sealed tube equipped with a screwed stopper, and the tube was filled with argon. The tube was heated to $150{ }^{\circ} \mathrm{C}$ for $5 \mathrm{~h}$. After being cooled to ambient temperature, the solution was concentrated in vacuo. The residue was purified by column chromatography on silica gel (EtOAc/hexane, 1:15) to provide $22.1 \mathrm{mg}(75 \%)$ of 40; TLC, $R_{f} 0.36($ EtOAc/hexane, $1: 5) ;[\alpha]^{24}{ }_{\mathrm{D}}+45.3(c$ 0.945, $\left.\mathrm{CHCl}_{3}\right)$; ${ }^{1} \mathrm{H}$ NMR $(270 \mathrm{MHz}) \delta 1.05(\mathrm{~d}, J=5.8 \mathrm{~Hz}, 3 \mathrm{H}), 1.07(\mathrm{~m}, 1 \mathrm{H}), 1.72(\mathrm{~m}, 2 \mathrm{H}), 1.96(\mathrm{~m}, 2 \mathrm{H})$, $2.35(\mathrm{~m}, 1 \mathrm{H}), 2.57(\mathrm{~m}, 2 \mathrm{H}), 2.66(\mathrm{~m}, 1 \mathrm{H}), 3.12-3.18(\mathrm{~m}, 3 \mathrm{H}), 3.80(\mathrm{~s}, 3 \mathrm{H}), 4.46,4.54(2 \mathrm{~d}, J=11.2 \mathrm{~Hz}, 1 \mathrm{H} \times$ 2), $5.56(\mathrm{~m}, 1 \mathrm{H}), 5.73(\mathrm{~m}, 1 \mathrm{H}), 6.87(\mathrm{~m}, 2 \mathrm{H}), 7.23-7.32(\mathrm{~m}, 11 \mathrm{H}), 7.41-7.44(\mathrm{~m}, 6 \mathrm{H}), 9.68(\mathrm{~d}, J=2.4 \mathrm{~Hz}$, $1 \mathrm{H}) ;{ }^{13} \mathrm{C}$ NMR (68 MHz) $\delta 18.28,29.72,32.42,33.81,36.71,39.62,43.42,53.62,55.23,61.13,72.02,86.50$, $92.06,113.75 \times 2,126.93 \times 3,127.74 \times 6,128.58 \times 6,128.66,129.21 \times 2,130.36,130.65,144.13 \times 3$, 159.15, 204.92; IR (neat) 3020, 2930, 1720, 1615, $1515 \mathrm{~cm}^{-1}$; HRMS calcd for $\mathrm{C}_{40} \mathrm{H}_{42} \mathrm{O}_{4}\left(\mathrm{M}^{+}\right) \mathrm{m} / z$ 586.3083, found 586.3083.

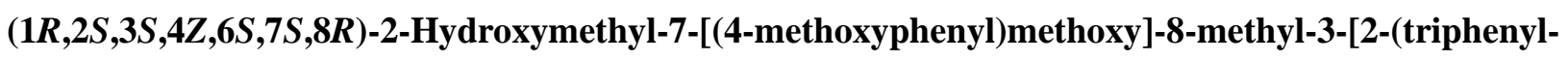
methoxy)ethyl]bicyclo[4.3.0]non-4-ene

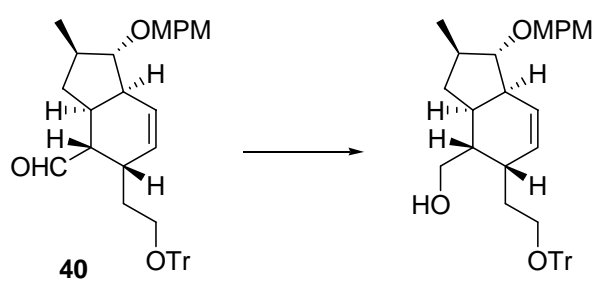

To a cooled $\left(0{ }^{\circ} \mathrm{C}\right)$, stirred solution of $\mathbf{4 0}(17.8 \mathrm{mg}, 0.0303 \mathrm{mmol})$ in $\mathrm{EtOH}(1 \mathrm{~mL})$ was added $\mathrm{NaBH}_{4}(1.1 \mathrm{mg}$, $0.029 \mathrm{mmol}$ ). The mixture was stirred for $2 \mathrm{~h}$ and then quenched with saturated aqueous $\mathrm{NH}_{4} \mathrm{Cl}$. This was diluted with $\mathrm{H}_{2} \mathrm{O}(10 \mathrm{~mL})$ and extracted with $\mathrm{CH}_{2} \mathrm{Cl}_{2}$. The combined organic layers were dried and concentrated in vacuo. The residue was purified by column chromatography on silica gel (EtOAc/hexane, 1:5) to provide $17.7 \mathrm{mg}$ (99\%) of the primary alcohol as a colorless oil; TLC, $R_{f} 0.33$ (EtOAc/hexane, 1:3); $[\alpha]^{24}+64.5\left(c 0.830, \mathrm{CHCl}_{3}\right) ;{ }^{1} \mathrm{H}$ NMR $(300 \mathrm{MHz}) \delta 1.04(\mathrm{~d}, J=6.6 \mathrm{~Hz}, 3 \mathrm{H}), 1.09(\mathrm{~m}, 1 \mathrm{H}), 1.53(\mathrm{~m}, 1 \mathrm{H})$, $1.62(\mathrm{~m}, 2 \mathrm{H}), 1.73(\mathrm{~m}, 1 \mathrm{H}), 1.84(\mathrm{~m}, 1 \mathrm{H}), 1.93(\mathrm{~m}, 1 \mathrm{H}), 2.28(\mathrm{~m}, 1 \mathrm{H}), 2.43(\mathrm{~m}, 1 \mathrm{H}), 2.47(\mathrm{~m}, 1 \mathrm{H}), 3.12(\mathrm{dd}, J$ = 6.1, $7.3 \mathrm{~Hz}, 1 \mathrm{H}), 3.18(\mathrm{~m}, 2 \mathrm{H}), 3.54(\mathrm{~m}, 2 \mathrm{H}), 3.79(\mathrm{~s}, 3 \mathrm{H}), 4.47,4.55(2 \mathrm{~d}, J=11.2 \mathrm{~Hz}, 1 \mathrm{H} \times 2), 5.48(\mathrm{~m}$, 
1H), $5.66(\mathrm{~m}, 1 \mathrm{H}), 6.87(\mathrm{~m}, 2 \mathrm{H}), 7.20-7.32(\mathrm{~m}, 11 \mathrm{H}), 7.43-7.46(\mathrm{~m}, 6 \mathrm{H}) ;{ }^{13} \mathrm{C} \mathrm{NMR}(75 \mathrm{MHz}) \delta 18.37,30.20$, $31.52,34.81,36.85,39.72,42.65,43.52,55.24,61.92,62.82,72.05,86.56,92.12,113.73 \times 2,126.88 \times 3$, $127.73 \times 6,128.64 \times 6,129.23 \times 2,129.44,129.74,130.86,144.26 \times 3,159.07$; IR (neat) 3400, 3020, 2930, $1615,1515 \mathrm{~cm}^{-1}$; HRMS calcd for $\mathrm{C}_{40} \mathrm{H}_{44} \mathrm{O}_{4}\left(\mathrm{M}^{+}\right) \mathrm{m} / \mathrm{z}, 588.3240$, found 588.3233 .

\section{Synthesis of $(E, E, Z)-1,6,8$-nonatriene 39}

The model IMDA substrate $\mathbf{3 9}$ was synthesized as shown in Scheme S2.
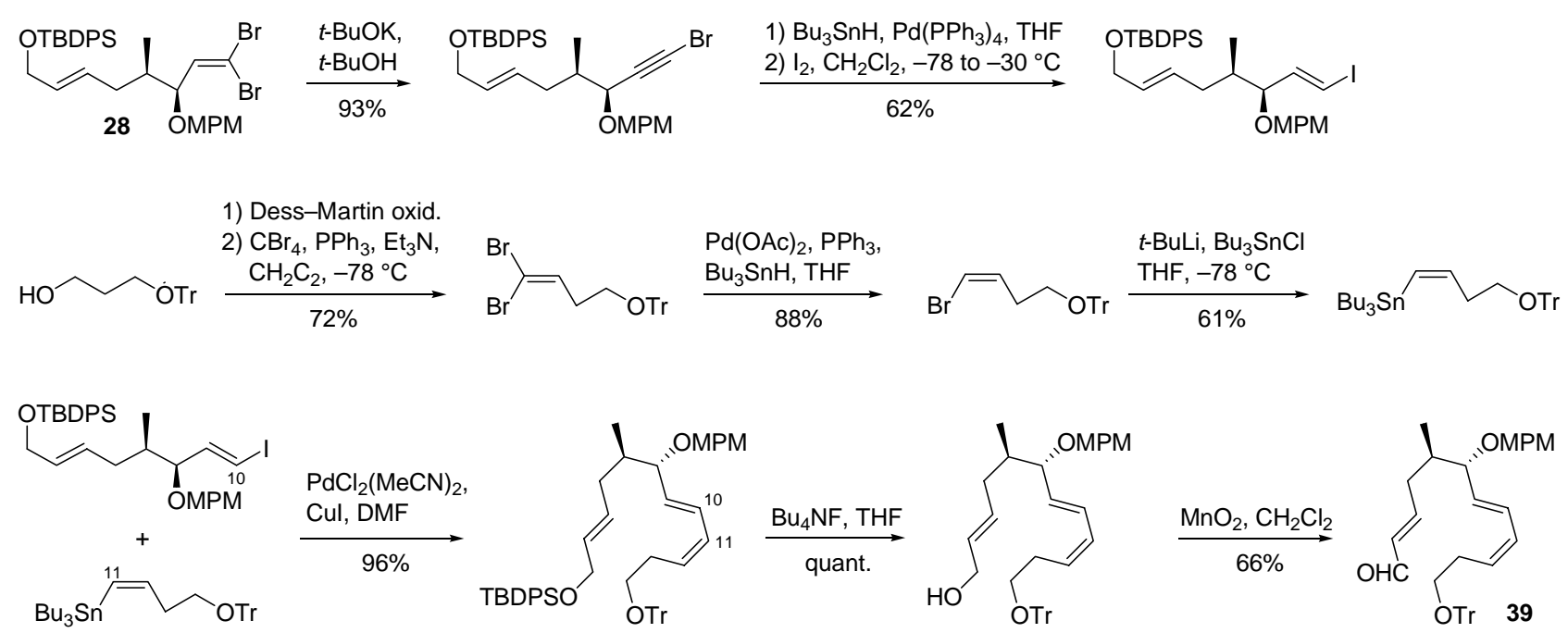

Scheme S2.

\section{(3S,4R,6E)-1-Bromo-8-( $t$-butyldiphenylsilyloxy)-3-[(4-methoxyphenyl)methoxy]-4-methyl-6-octen-1-} yne

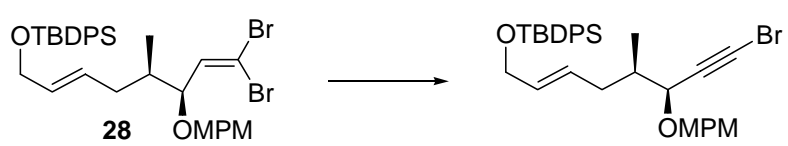

To a stirred solution of $28(608 \mathrm{mg}, 0.904 \mathrm{mmol})$ in $t$-BuOH $(10 \mathrm{~mL})$ was added $t$-BuOK $(203 \mathrm{mg}, 1.81$ $\mathrm{mmol})$. The mixture was stirred for $15 \mathrm{~h}$ and then diluted with $0.1 \mathrm{M}$ phosphate buffer $(20 \mathrm{~mL})$. This was extracted with $\mathrm{CH}_{2} \mathrm{Cl}_{2}$. The combined organic layers were dried and concentrated in vacuo. The residue was purified by column chromatography on silica gel (EtOAc/hexane, 1:30) to provide $497 \mathrm{mg}$ (93\%) of the bromoalkyne as a colorless oil; TLC, $\mathrm{R}_{f} 0.67$ (EtOAc/hexane, 1:6); $[\alpha]^{26}{ }_{\mathrm{D}}-56.0\left(c 1.95, \mathrm{CHCl}_{3}\right) ;{ }^{1} \mathrm{H}-\mathrm{NMR}$ $(300 \mathrm{MHz}) \delta 0.98(\mathrm{~d}, J=6.8 \mathrm{~Hz}, 3 \mathrm{H}), 1.05(\mathrm{~s}, 9 \mathrm{H}), 1.80(\mathrm{~m}, 1 \mathrm{H}), 1.95(\mathrm{~m}, 1 \mathrm{H}), 2.31(\mathrm{~m}, 1 \mathrm{H}), 3.78(\mathrm{~s}, 3 \mathrm{H})$, $3.94(\mathrm{~d}, J=4.9 \mathrm{~Hz}, 1 \mathrm{H}), 4.14(\mathrm{~m}, 2 \mathrm{H}), 4.37,4.71(\mathrm{~d}, J=11.5 \mathrm{~Hz}, 1 \mathrm{H} \times 2), 5.47-5.63(\mathrm{~m}, 2 \mathrm{H}), 6.86(\mathrm{~m}, 2 \mathrm{H})$, 
$7.26(\mathrm{~m}, 2 \mathrm{H}), 7.35-7.42(\mathrm{~m}, 6 \mathrm{H}), 7.66-7.68(\mathrm{~m}, 4 \mathrm{H}) ;{ }^{13} \mathrm{C}-\mathrm{NMR}(75 \mathrm{MHz}) \delta 15.15,19.21,26.83 \times 3,35.12$, $38.39,45.45,55.24,64.42,70.49,72.77,78.74,113.72 \times 2,127.60 \times 4,128.67,129.56 \times 2,129.59 \times 2$, $129.89,130.81,133.87 \times 2,135.53 \times 4,159.22$; IR (neat) $2930,2200,1615,1515 \mathrm{~cm}^{-1}$; HRMS calcd for $\mathrm{C}_{29} \mathrm{H}_{30} \mathrm{O}_{3} \mathrm{SiBr}\left(\mathrm{M}^{+}-t-\mathrm{Bu}\right) \mathrm{m} / z$ 533.1148, found 533.1143.

\section{$(1 E, 3 S, 4 R, 6 E)-8$-(t-Butyldiphenylsilyloxy)-1-iodo-3-[(4-methoxyphenyl)methoxy]-4-methyl-1,6-octa- diene}

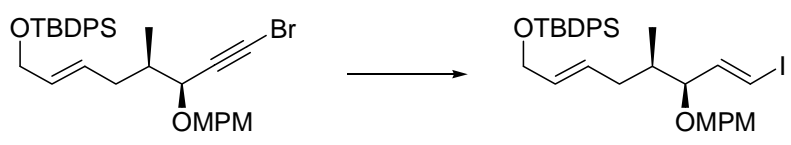

The following reaction was carried out under argon. To a cooled $\left(0{ }^{\circ} \mathrm{C}\right)$, stirred solution of the bromoalkyne (494 mg, $0.835 \mathrm{mmol})$ in THF $(10 \mathrm{~mL})$ was added $\mathrm{Pd}\left(\mathrm{PPh}_{3}\right)_{4}(48.0 \mathrm{mg}, 0.0415 \mathrm{mmol})$. Then $\mathrm{Bu}_{3} \mathrm{SnH}(0.77$ $\mathrm{mL}, 2.89 \mathrm{mmol}$ ) was added dropwise. The mixture was stirred for $1 \mathrm{~h}$ and then concentrated in vacuo. The residue was purified by column chromatography on silica gel (EtOAc/hexane, 1:200) to provide $555 \mathrm{mg}$ (72\%) of a stannylalkene as a colorless oil.

The following reaction was carried out under argon. To a cooled $\left(-78{ }^{\circ} \mathrm{C}\right)$, stirred solution of the stannylalkene obtained above $(555 \mathrm{mg}, 0.690 \mathrm{mmol})$ in $\mathrm{CH}_{2} \mathrm{Cl}_{2}(10 \mathrm{~mL})$ was added iodine $(193 \mathrm{mg}, 0.759$ $\mathrm{mmol})$. The mixture was warmed to $-25^{\circ} \mathrm{C}$ over $1 \mathrm{~h}$ and then diluted with a mixture of saturated aqueous $\mathrm{NaHCO}_{3}(7 \mathrm{~mL})$ and $20 \% \mathrm{Na}_{2} \mathrm{~S}_{2} \mathrm{O}_{3}(7 \mathrm{~mL})$ and extracted with $\mathrm{CH}_{2} \mathrm{Cl}_{2}$. The combined organic layers were dried and concentrated in vacuo. The residue was purified by column chromatography on silica gel (EtOAc/hexane, 1:150) to provide $398 \mathrm{mg}$ (62\%, 2 steps) of the (E)-iodoalkene as a colorless oil.; TLC, $\mathrm{R}_{f}$ 0.47 (EtOAc/hexane, 1:8); $[\alpha]^{24}{ }_{\mathrm{D}}-30.2\left(c 1.96, \mathrm{CHCl}_{3}\right) ;{ }^{1} \mathrm{H}-\mathrm{NMR}(270 \mathrm{MHz}) \delta 0.91(\mathrm{~d}, J=6.8 \mathrm{~Hz}, 3 \mathrm{H})$, $1.05(\mathrm{~s}, 9 \mathrm{H}), 1.67,(1 \mathrm{H}, \mathrm{m}), 1.83,(\mathrm{~m}, 1 \mathrm{H}), 2.20(\mathrm{~m}, 1 \mathrm{H}), 3.56(\mathrm{dd}, J=5.4,7.7 \mathrm{~Hz}, 1 \mathrm{H}), 3.79(\mathrm{~s}, 3 \mathrm{H}), 4.14(\mathrm{~m}$, 2H), 4.24, $4.51(2 \mathrm{~d}, J=11.5 \mathrm{~Hz}, 1 \mathrm{H} \times 2), 5.46-5.62(\mathrm{~m}, 2 \mathrm{H}), 6.24(\mathrm{~d}, J=14.5 \mathrm{~Hz}, 1 \mathrm{H}), 6.48(\mathrm{dd}, J=7.7$, $14.5 \mathrm{~Hz}, 1 \mathrm{H}), 6.86(\mathrm{~m}, 2 \mathrm{H}), 7.23(\mathrm{~m}, 2 \mathrm{H}), 7.34-7.42(6 \mathrm{H}, \mathrm{m}), 7.66-7.69(4 \mathrm{H}, \mathrm{m}) ;{ }^{13} \mathrm{C}-\mathrm{NMR}(75 \mathrm{MHz}) \delta$ $14.92,19.23,26.83 \times 3,35.40,37.65,55.25,64.45,70.35,78.20,84.40,113.75 \times 2,127.60 \times 4,128.80$, $129.26 \times 2,129.57 \times 2,130.36,130.69,133.85 \times 2,135.53 \times 4,145.79,159.12$; IR (neat) $2930,1615,1515$ $\mathrm{cm}^{-1}$; HRMS calcd for $\mathrm{C}_{29} \mathrm{H}_{32} \mathrm{O}_{3} \mathrm{SiI}\left(\mathrm{M}^{+}-t-\mathrm{Bu}\right) \mathrm{m} / z$ 583.1166, found 583.1168.

\section{(Z)-1-Bromo-4-triphenylmethoxy-1-butene}

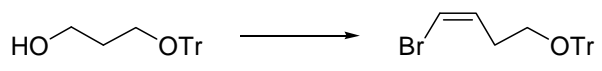


To a stirred solution of the known alcohol ${ }^{6}(2.18 \mathrm{~g}, 6.85 \mathrm{mmol})$ in $\mathrm{CH}_{2} \mathrm{Cl}_{2}(40 \mathrm{~mL})$ were added sodium bicarbonate $(1.96 \mathrm{~g}, 23.8 \mathrm{mmol})$ and Dess-Martin periodinane $(4.94 \mathrm{~g}, 11.7 \mathrm{mmol})$. The mixture was stirred for $2.5 \mathrm{~h}$ and then diluted with saturated aqueous $\mathrm{NaHCO}_{3}-20 \%$ aqueous $\mathrm{Na}_{2} \mathrm{~S}_{2} \mathrm{O}_{3}(1: 1,50 \mathrm{~mL})$ at $0{ }^{\circ} \mathrm{C}$. The mixture was stirred for $30 \mathrm{~min}$ and then the organic layer was separated. The aqueous layer was extracted with $\mathrm{CH}_{2} \mathrm{Cl}_{2}$. The combined organic layers were dried and concentrated in vacuo to give the crude aldehyde.

To a cooled $\left(0^{\circ} \mathrm{C}\right)$, stirred solution of $\mathrm{CBr}_{4}(7.95 \mathrm{~g}, 24.0 \mathrm{mmol})$ in $\mathrm{CH}_{2} \mathrm{Cl}_{2}(10 \mathrm{~mL})$ was added a solution of triphenylphosphine $(12.6 \mathrm{~g}, 48.0 \mathrm{mmol})$ in $\mathrm{CH}_{2} \mathrm{Cl}_{2}(15 \mathrm{~mL})$. The mixture was stirred for $30 \mathrm{~min}$ at $0{ }^{\circ} \mathrm{C}$ and then $\mathrm{Et}_{3} \mathrm{~N}(8.6 \mathrm{~mL}, 59.9 \mathrm{mmol})$ and a solution the crude aldehyde in $\mathrm{CH}_{2} \mathrm{Cl}_{2}$ were added at $-78{ }^{\circ} \mathrm{C}$. The mixture was stirred for $2.5 \mathrm{~h}$ at $-78{ }^{\circ} \mathrm{C}$ and then quenched with saturated aqueous $\mathrm{NaHCO}_{3}$. This was diluted with saturated aqueous $\mathrm{NaHCO}_{3}(50 \mathrm{~mL})$ and this was extracted with $\mathrm{CH}_{2} \mathrm{Cl}_{2}$. The combined organic layers were dried and concentrated in vacuo. The residue was purified by column chromatography on silica gel $\left(\mathrm{Et}_{3} \mathrm{~N} / \mathrm{EtOAc} / \mathrm{hexane}, 1: 2: 100\right)$ to provide $2.32 \mathrm{~g}$ (72\% for 2 steps) of the dibromoalkene as a colorless oil.

The following reaction was carried out under argon. To a stirred solution of $\mathrm{PPh}_{3}(268 \mathrm{mg}, 1.02 \mathrm{mmol})$ in degassed toluene $(30 \mathrm{~mL})$ was added $\mathrm{Pd}(\mathrm{OAc})_{2}(57.0 \mathrm{mg}, 0.254 \mathrm{mmol})$. The mixture was stirred for $30 \mathrm{~min}$ and then the dibromoalkene $(2.32 \mathrm{~g}, 4.92 \mathrm{mmol})$ in degassed toluene $(20 \mathrm{~mL})$ and $\mathrm{Bu}_{3} \mathrm{SnH}(2.3 \mathrm{~mL}, 8.4$ mmol) were added. The mixture was stirred for $4 \mathrm{~h}$ and then concentrated in vacuo. The residue was purified by column chromatography on silica gel $\left(\mathrm{Et}_{3} \mathrm{~N} / \mathrm{hexane}, 1: 100\right)$ to provide $1.70 \mathrm{~g}(88 \%)$ of the (Z)-bromoalkene as a colorless oil; TLC, $\mathrm{R}_{f} 0.42$ (EtOAc/hexane, 1:16); ${ }^{1} \mathrm{H}-\mathrm{NMR}(300 \mathrm{MHz}) \delta 2.52$ (q, $J=$ $6.3 \mathrm{~Hz}, 2 \mathrm{H}), 3.15(\mathrm{t}, J=6.3 \mathrm{~Hz}, 2 \mathrm{H}), 6.17-6.25(\mathrm{~m}, 2 \mathrm{H}), 7.21-7.33(\mathrm{~m}, 9 \mathrm{H}), 7.43-7.46(\mathrm{~m}, 6 \mathrm{H})$; ${ }^{13} \mathrm{C}-\mathrm{NMR}$ $(68 \mathrm{MHz}) \delta 30.78,61.82,86.56,109.12,126.93 \times 3,127.77 \times 6,128.66 \times 6,131.94,144.15 \times 3$; IR (neat) 3060, 2930, 1610, $1600 \mathrm{~cm}^{-1}$; HRMS calcd for $\mathrm{C}_{23} \mathrm{H}_{21} \mathrm{OBr}\left(\mathrm{M}^{+}\right) \mathrm{m} / z$ 392.0776, found 392.0778 .

\section{(Z)-1-Tributylstannanyl-4-triphenylmethoxy-1-butene}

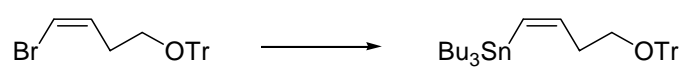

The following reaction was carried out under argon. To a cooled $\left(-78{ }^{\circ} \mathrm{C}\right)$, stirred solution of (Z)-bromoalkene (294 mg, $0.747 \mathrm{mmol})$ in $\mathrm{Et}_{2} \mathrm{O}(6 \mathrm{~mL})$ was added $t$-BuLi $(1.3 \mathrm{~mL}$ of $1.40 \mathrm{M}$ in pentane, 1.9 mmol). The mixture was stirred at $-78{ }^{\circ} \mathrm{C}$ for $1 \mathrm{~h}$ and then $\mathrm{Bu}_{3} \mathrm{SnCl}(0.26 \mathrm{~mL}, 0.97 \mathrm{mmol})$ was added. The mixture was stirred at $-78{ }^{\circ} \mathrm{C}$ for $3 \mathrm{~h}$ and then quenched with $0.1 \mathrm{M}$ phosphate buffer. This was diluted with EtOAc $(10 \mathrm{~mL})$, and washed with brine. The organic layer was dried and concentrated in vacuo. The residue was purified by column chromatography on silica gel $\left(\mathrm{Et}_{3} \mathrm{~N} /\right.$ hexane, $\left.1: 100\right)$ to provide $274 \mathrm{mg}(61 \%)$ of the (Z)-stannylalkene as a colorless oil; TLC, $\mathrm{R}_{f} 0.63$ (EtOAc/hexane, 1:16); ${ }^{1} \mathrm{H}-\mathrm{NMR}(300 \mathrm{MHz}) \delta 0.84-0.92$ $(\mathrm{m}, 15 \mathrm{H}), 1.28(\mathrm{~m}, 6 \mathrm{H}), 1.48(\mathrm{~m}, 6 \mathrm{H}), 2.38(\mathrm{q}, J=6.8 \mathrm{~Hz}, 2 \mathrm{H}), 3.09(\mathrm{t}, J=6.8 \mathrm{~Hz}, 2 \mathrm{H}), 5.89$ (d, $J=12.6 \mathrm{~Hz}$,

\footnotetext{
${ }^{6}$ Bertolini, G.; Casagrande, C.; Norcini, G.; Santangelo, F. Synth. Commun. 1994, 24, 1833-1845.
} 
$\left.{ }^{2} J_{\mathrm{Sn}-\mathrm{H}}=70.8 \mathrm{~Hz}, 1 \mathrm{H}\right), 6.54(\mathrm{dt}, J=6.8,12.6 \mathrm{~Hz}, 1 \mathrm{H}), 7.20-7.31(\mathrm{~m}, 9 \mathrm{H}), 7.43-7.46(\mathrm{~m}, 6 \mathrm{H}) ;{ }^{13} \mathrm{C}-\mathrm{NMR}(68$ MHz) $\delta 10.19 \times 3,13.71 \times 3,27.30 \times 3,29.17 \times 3,37.46,63.47,86.36,126.82 \times 3,127.68 \times 6,128.69 \times 6,130.22$, 144.30×3, 145.36; IR (neat) 2920, $1600 \mathrm{~cm}^{-1}$; HRMS calcd for $\mathrm{C}_{35} \mathrm{H}_{48} \mathrm{OSn}\left(\mathrm{M}^{+}\right) \mathrm{m} / \mathrm{z} 604.2727$, found 604.2722 .

$(2 E, 5 R, 6 S, 7 E, 9 Z)-1-(t$-Butyldiphenylsilyloxy)-6-[(4-methoxyphenyl)methoxy]-5-methyl-12-triphenylmethoxy-2,7,9-dodecatriene

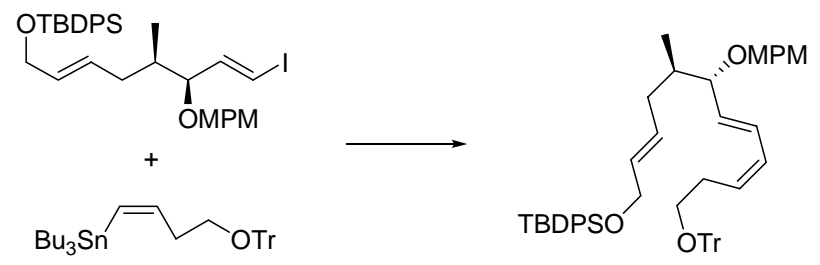

The following reaction was carried out under argon. To a stirred solution of the iodide (119 $\mathrm{mg}, 0.186 \mathrm{mmol}$ ) and the stannane $(173 \mathrm{mg}, 0.292 \mathrm{mmol})$ in degassed DMF $(5 \mathrm{~mL})$ were added $\mathrm{PdCl}_{2}\left(\mathrm{MeCN}_{2}\right.$ (4.8 $\mathrm{mg}, 0.019$ $\mathrm{mmol})$ and $\mathrm{CuI}(35.3 \mathrm{mg}, 0.186 \mathrm{mmol})$. The mixture was stirred for $20 \mathrm{~h}$ and then diluted with saturated aqueous $\mathrm{NaHCO}_{3}(10 \mathrm{~mL})$. This was extracted with $\mathrm{CH}_{2} \mathrm{Cl}_{2}$. The combined organic layers were dried and concentrated in vacuo. The residue was purified by column chromatography on silica gel $\left(\mathrm{Et}_{2} \mathrm{O} /\right.$ hexane, 1:70) to provide $145 \mathrm{mg}(96 \%)$ of the triene as a colorless oil; TLC, $\mathrm{R}_{f} 0.38$ (EtOAc/hexane, 1:8); $[\alpha]_{\mathrm{D}}^{26}-5.2(c$ 1.27, $\left.\mathrm{CHCl}_{3}\right) ;{ }^{1} \mathrm{H}-\mathrm{NMR}(300 \mathrm{MHz}) \delta 0.91(\mathrm{~d}, J=6.6 \mathrm{~Hz}, 3 \mathrm{H}), 1.04(\mathrm{~s}, 9 \mathrm{H}), 1.66(\mathrm{~m}, 1 \mathrm{H}), 1.80(\mathrm{~m}, 1 \mathrm{H}), 2.23$ $(\mathrm{m}, 1 \mathrm{H}), 2.50(\mathrm{q}, J=6.8 \mathrm{~Hz}, 2 \mathrm{H}), 3.12(\mathrm{t}, J=6.8 \mathrm{~Hz}, 2 \mathrm{H}), 3.61(\mathrm{dd}, J=5.6,7.8 \mathrm{~Hz}, 1 \mathrm{H}), 3.78(\mathrm{~s}, 3 \mathrm{H}), 4.14$ (m, 2H), 4.22, 4.49 (2d, $J=11.5 \mathrm{~Hz}, 1 \mathrm{H} \times 2), 5.45-5.64(\mathrm{~m}, 4 \mathrm{H}), 6.11(\mathrm{t}, J=11.1 \mathrm{~Hz}, 1 \mathrm{H}), 6.43$ (dd, $J=11.1$, $15.4 \mathrm{~Hz}, 1 \mathrm{H}), 6.84(\mathrm{~m}, 2 \mathrm{H}), 7.18-7.46(\mathrm{~m}, 23 \mathrm{H}), 7.66-7.69(\mathrm{~m}, 4 \mathrm{H}) ;{ }^{13} \mathrm{C}-\mathrm{NMR}(68 \mathrm{MHz}) \delta 15.09,19.21$, $26.81 \times 3,28.74,35.68,38.41,55.20,63.15,64.50,69.83,82.93,86.45,113.63 \times 2,126.88 \times 3,127.57 \times 4$, $127.71 \times 6,128.37 \times 2,128.63 \times 6,129.21 \times 2,129.46 \times 2,129.53 \times 2,130.27,130.99,133.15,133.85 \times 2$, $135.52 \times 4,144.24 \times 3,158.93$; IR (neat) $2930,1610,1515 \mathrm{~cm}^{-1} ; \mathrm{HRMS}$ calcd for $\mathrm{C}_{52} \mathrm{H}_{53} \mathrm{O}_{4} \mathrm{Si}\left(\mathrm{M}^{+}-t-\mathrm{Bu}\right) \mathrm{m} / z$ 769.3713, found 769.3709 .

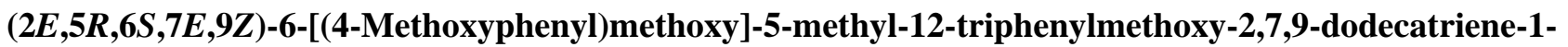
ol

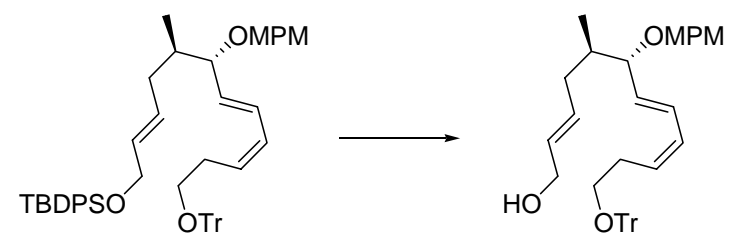

To a cooled $\left(0{ }^{\circ} \mathrm{C}\right)$, stirred solution of the TBDPS ether $(151 \mathrm{mg}, 0.185 \mathrm{mmol})$ in THF $(3 \mathrm{~mL})$ was added 
$\mathrm{Bu}_{4} \mathrm{NF}(0.096 \mathrm{~mL}$ of $1.0 \mathrm{M}$ solution in THF, $0.096 \mathrm{mmol})$ and the mixture was stirred for $5 \mathrm{~h}$. Then $\mathrm{Bu}_{4} \mathrm{NF}$ $(0.027 \mathrm{~mL}$ of $1.0 \mathrm{M}$ solution in THF, $0.027 \mathrm{mmol})$ was added and stirred for $14 \mathrm{~h}$. The reaction mixture was diluted with brine $(10 \mathrm{~mL})$ and extracted with $\mathrm{CH}_{2} \mathrm{Cl}_{2}$. The combined organic layers were dried and concentrated in vacuo. The residue was purified by column chromatography on silica gel (Et ${ }_{3} \mathrm{~N} / \mathrm{EtOAc} /$ hexane, 1:25:75) to provide $105 \mathrm{mg}$ (quant.) of the primary alcohol as a colorless oil; TLC, $R_{f}$ 0.59 (EtOAc/hexane, 1:1); $[\alpha]^{23}{ }_{\mathrm{D}}-9.8\left(c^{0} 0.965, \mathrm{CHCl}_{3}\right) ;{ }^{1} \mathrm{H}$ NMR $(300 \mathrm{MHz}) \delta 0.92(\mathrm{~d}, J=6.8 \mathrm{~Hz}, 3 \mathrm{H})$, $1.70-1.82(\mathrm{~m}, 2 \mathrm{H}), 2.24(\mathrm{~m}, 1 \mathrm{H}), 2.51(\mathrm{q}, J=6.9 \mathrm{~Hz}, 2 \mathrm{H}), 3.14(\mathrm{t}, J=6.9 \mathrm{~Hz}, 2 \mathrm{H}), 3.62(\mathrm{dd}, J=5.4,7.8 \mathrm{~Hz}$, $1 \mathrm{H}), 3.79(\mathrm{~s}, 3 \mathrm{H}), 4.04-4.06(\mathrm{~m}, 2 \mathrm{H}), 4.22,4.50(2 \mathrm{~d}, J=11.5 \mathrm{~Hz}, 1 \mathrm{H} \times 2), 5.45-5.65(\mathrm{~m}, 4 \mathrm{H}), 6.11(\mathrm{t}, J=$ $10.9 \mathrm{~Hz}, 1 \mathrm{H}), 6.44(\mathrm{dd}, J=10.9,15.1 \mathrm{~Hz}, 1 \mathrm{H}), 6.85(\mathrm{~m}, 2 \mathrm{H}), 7.19-7.31(\mathrm{~m}, 11 \mathrm{H}), 7.43-7.46(\mathrm{~m}, 6 \mathrm{H}) ;{ }^{13} \mathrm{C}$ NMR $(68 \mathrm{MHz}) \delta 15.15,28.74,35.65,38.27,55.23,63.15,63.75,69.77,82.67,86.47,113.63 \times 2,126.88 \times$ $3,127.71 \times 6,128.55 \times 2,128.63 \times 6,129.27 \times 2,129.41,130.39,130.94,131.60,132.92,144.21 \times 3$, 158.96; IR (neat) 3400, 2930, 1610, $1515 \mathrm{~cm}^{-1}$; HRMS calcd for $\mathrm{C}_{40} \mathrm{H}_{44} \mathrm{O}_{4}\left(\mathrm{M}^{+}\right) \mathrm{m} / \mathrm{z} 588.3240$, found 588.3239 .

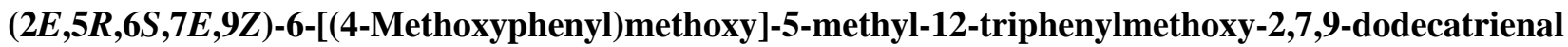
(39)
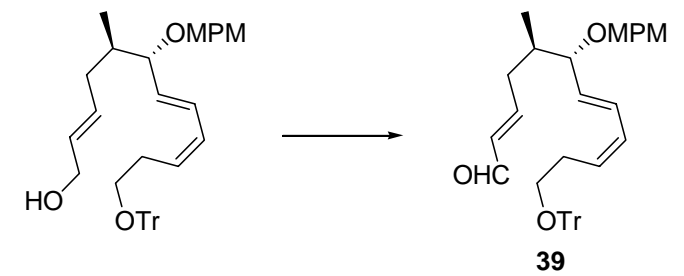

To a cooled $\left(0{ }^{\circ} \mathrm{C}\right)$, stirred solution of the primary alcohol $(85.6 \mathrm{mg}, 0.145 \mathrm{mmol})$ in $\mathrm{CH}_{2} \mathrm{Cl}_{2}(1.5 \mathrm{~mL})$ was added $\mathrm{MnO}_{2}(728 \mathrm{mg}, 8.37 \mathrm{mmol})$. The mixture was stirred for $1 \mathrm{~h}$, and the insoluble materials were filtered off and washed well with EtOH. The combined filtrate and washings were concentrated in vacuo. The residue was purified by column chromatography on silica gel (EtOAc/hexane, 1:100) to provide $56.7 \mathrm{mg}(66 \%)$ of 39 as a colorless oil; TLC, $R_{f} 0.80$ (EtOAc/hexane, 1:1); $[\alpha]^{23}{ }_{\mathrm{D}}-15\left(c 0.38, \mathrm{CHCl}_{3}\right) ;{ }^{1} \mathrm{H}$ NMR (300 MHz) $\delta$ $0.94(\mathrm{~d}, J=6.8 \mathrm{~Hz}, 3 \mathrm{H}), 1.89(\mathrm{~m}, 1 \mathrm{H}), 2.09(\mathrm{~m}, 1 \mathrm{H}), 2.48-2.55(\mathrm{~m}, 3 \mathrm{H}), 3.14(\mathrm{t}, J=6.6 \mathrm{~Hz}, 2 \mathrm{H}), 3.66(\mathrm{dd}, J$ $=5.3,8.2 \mathrm{~Hz}, 1 \mathrm{H}), 3.80(\mathrm{~s}, 3 \mathrm{H}), 4.21,4.51(2 \mathrm{~d}, J=11.5 \mathrm{~Hz}, 1 \mathrm{H} \times 2), 5.49-5.63(\mathrm{~m}, 2 \mathrm{H}), 6.00-6.15(\mathrm{~m}, 2 \mathrm{H})$, $6.48(\mathrm{dd}, J=11.4,15.2 \mathrm{~Hz}, 1 \mathrm{H}), 6.75(\mathrm{dt}, J=6.8,15.2 \mathrm{~Hz}, 1 \mathrm{H}), 6.86(\mathrm{~m}, 2 \mathrm{H}), 7.19-7.30(\mathrm{~m}, 11 \mathrm{H}), 7.43-7.46$ $(\mathrm{m}, 6 \mathrm{H}), 9.45(\mathrm{~d}, J=7.8 \mathrm{~Hz}, 1 \mathrm{H}) ;{ }^{13} \mathrm{C}$ NMR $(68 \mathrm{MHz}) \delta 15.35,28.77,36.20,37.87,55.26,63.09,69.83$, $82.33,86.50,113.72 \times 2,126.91 \times 3,127.74 \times 6,128.63 \times 6,129.18 \times 3,129.35 \times 2,130.56,131.86,134.05$, 144.21 × 3, 157.89, 159.10, 194.00; IR (neat) 2940, 1695, 1615, $1515 \mathrm{~cm}^{-1}$; HRMS calcd for $\mathrm{C}_{40} \mathrm{H}_{42} \mathrm{O}_{4}\left(\mathrm{M}^{+}\right)$ $\mathrm{m} / \mathrm{z}$ 586.3083, found 586.3085 . 
Intramolecular Diels-Alder reaction of 39<smiles>COC(C)C(C)C/C=C/CO</smiles>

39

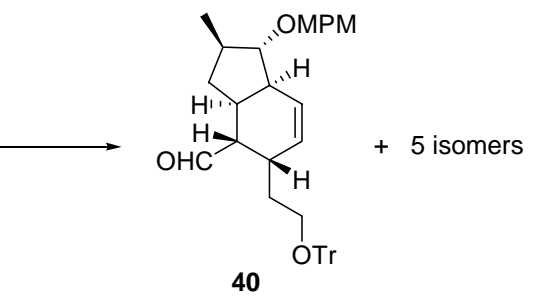

40

Compound 39 (56.2 mg, $0.0959 \mathrm{mmol})$ was dissolved in degassed toluene $(5 \mathrm{~mL})$, and a crystal of BHT was added. The solution was transferred into a $20 \mathrm{~mL}$ sealed tube equipped with a screwed stopper, and the tube was filled with argon. The tube was heated to $185^{\circ} \mathrm{C}$ for $255 \mathrm{~h}$. After being cooled to ambient temperature, the solution was concentrated in vacuo. The residue was purified by column chromatography on silica gel (EtOAc/hexane, 1:30) to provide $39.9 \mathrm{mg}$ (71\%) of partly purified mixtures of cycloadducts (1:1:1:0.1:0.1:0.1). The ${ }^{1} \mathrm{H}$ NMR analysis of the mixtures revealed that one of the major cycloadducts is $\mathbf{4 0 .}$ 


\subsection{Synthesis and Examination of IMDA Substrates 14-17}

$(2 E, 5 R, 6 S, 7 Z, 9 E, 12 R, 14 R)-12,14-B i s(t$-butyldimethylsilyloxy)-1-(t-butyldiphenylsilyloxy)-15-(2,2-dimethyl-1,3-dioxin-4-one-6-yl)-6-[(4-methoxyphenyl)methoxy]-5-methyl-2,7,9-pentadecatriene (37)

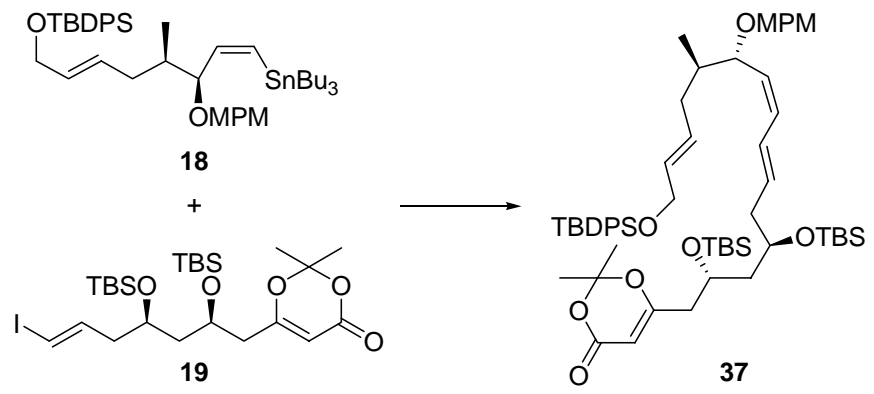

The following reaction was carried out under argon. To a stirred solution of 18 (1.69 g, $2.10 \mathrm{mmol})$ and 19 (1.06 $\mathrm{g}, 1.74 \mathrm{mmol})$ in degassed DMSO-THF (1:1, $40 \mathrm{~mL})$ was added $\mathrm{CuCl}(254 \mathrm{mg}, 2.57 \mathrm{mmol})$. Then a solution of $\mathrm{Pd}\left(\mathrm{PPh}_{3}\right)_{4}(101 \mathrm{mg}, 0.0877 \mathrm{mmol})$ in degassed THF (3 mL) was added. The mixture was stirred for $1 \mathrm{~h}$ and then $\mathrm{Pd}\left(\mathrm{PPh}_{3}\right)_{4}(10.5 \mathrm{mg}, 0.00909 \mathrm{mmol})$ was added. The mixture was stirred for $1 \mathrm{~h}$ and then diluted with saturated brine-saturated aqueous $\mathrm{NaHCO}_{3}(1: 1,300 \mathrm{~mL})$. This was extracted with $\mathrm{Et}_{2} \mathrm{O}$. The combined organic layers were dried and concentrated in vacuo. The residue was purified by column chromatography on silica gel (EtOAc/hexane, 1:10) to provide $1.68 \mathrm{~g}$ (97\%) of 37 as a colorless oil; TLC, $\mathrm{R}_{f}$ 0.57 (EtOAc/hexane, 1:3); $[\alpha]^{21}{ }_{\mathrm{D}}-25.9\left(\mathrm{c} 1.36, \mathrm{CHCl}_{3}\right) ;{ }^{1} \mathrm{H}-\mathrm{NMR}(300 \mathrm{MHz}) \delta 0.04 \times 2,0.06(3 \mathrm{~s}$, total $12 \mathrm{H})$, $0.86,0.89(2 \mathrm{~s}, 9 \mathrm{H} \times 2), 0.93(\mathrm{~d}, J=6.3 \mathrm{~Hz}, 3 \mathrm{H}), 1.04(\mathrm{~s}, 9 \mathrm{H}), 1.66,1.68(2 \mathrm{~s}, 3 \mathrm{H} \times 2), 1.59-1.79(\mathrm{~m}, 4 \mathrm{H})$, 2.17-2.34 (m, 4H), $2.41(\mathrm{dd}, J=4.3,13.8 \mathrm{~Hz}, 1 \mathrm{H}), 3.79(\mathrm{~s}, 3 \mathrm{H}), 3.79(\mathrm{~m}, 1 \mathrm{H}), 4.01(\mathrm{dd}, J=5.9,9.3 \mathrm{~Hz}, 1 \mathrm{H})$, $4.09(\mathrm{~m}, 1 \mathrm{H}), 4.14(\mathrm{~d}, J=4.2 \mathrm{~Hz}, 2 \mathrm{H}), 4.21,4.49(2 \mathrm{~d}, J=11.5 \mathrm{~Hz}, 1 \mathrm{H} \times 2), 5.27(\mathrm{~s}, 1 \mathrm{H}), 5.30(\mathrm{t}, J=9.3 \mathrm{~Hz}$, 1H), 5.47-5.72 (m, 3H), 6.18-6.29 (m, 2H), $6.85(\mathrm{~m}, 2 \mathrm{H}), 7.23(\mathrm{~m}, 2 \mathrm{H}), 7.33-7.41(\mathrm{~m}, 6 \mathrm{H}), 7.66-7.69(\mathrm{~m}$, $4 \mathrm{H}) ;{ }^{13} \mathrm{C}-\mathrm{NMR}(75 \mathrm{MHz}) \delta-4.71,-4.59,-4.43,-4.08,15.15,17.88,17.95,19.16,24.30,25.71 \times 3,25.81 \times 4$, $26.78 \times 3,35.42,38.46,41.12,41.68,44.87,55.15,64.47,66.60,68.96,69.58,77.59,95.60,106.26,113.57 \times 2$, $127.55 \times 4,128.06,129.20 \times 2,129.43,129.51 \times 3,130.25,130.96,131.96,132.06,133.82 \times 2,135.46 \times 4,158.94$, 160.89, 169.04; IR (neat) 2930, 1730, 1640, 1615, $1515 \mathrm{~cm}^{-1}$; HRMS (FAB) calcd for $\mathrm{C}_{55} \mathrm{H}_{83} \mathrm{O}_{7} \mathrm{Si}_{3}$ $\left(\mathrm{M}^{+}\right.$-acetone $\left.+\mathrm{H}\right) \mathrm{m} / \mathrm{z}$ 939.5447, found 939.5452 . 

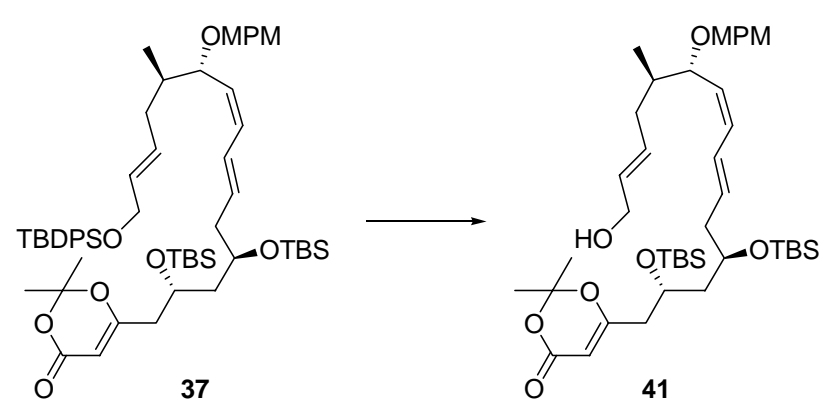

To a cooled $\left(0{ }^{\circ} \mathrm{C}\right)$, stirred solution of $37(1.68 \mathrm{~g}, 1.68 \mathrm{mmol})$ in $\mathrm{MeOH}(35 \mathrm{~mL})$ was added $\mathrm{NH}_{4} \mathrm{~F}(351 \mathrm{mg}$, $9.48 \mathrm{mmol})$. The mixture was stirred for $14 \mathrm{~h}$ and then $\mathrm{NH}_{4} \mathrm{~F}(35.5 \mathrm{mg}, 0.958 \mathrm{mmol})$ was added. The mixture was stirred for $10 \mathrm{~h}$ and quenched with saturated aqueous $\mathrm{NaHCO}_{3}$. This was diluted with saturated aqueous $\mathrm{NaHCO}_{3}(200 \mathrm{~mL})$, and extracted with $\mathrm{CH}_{2} \mathrm{Cl}_{2}$. The combined organic layers were dried and concentrated in vacuo. The residue was purified by column chromatography on silica gel (EtOAc/hexane, 1:8 to 1:3) to provide $1.20 \mathrm{~g}(94 \%)$ of $\mathbf{4 1}$ as a colorless oil, and $28.8 \mathrm{mg}(2 \%)$ of $\mathbf{3 7}$ was recovered; TLC, $\mathrm{R}_{f} 0.53$ (EtOAc/hexane, 1:1); $[\alpha]^{20}{ }_{\mathrm{D}}-22.8\left(c 1.17, \mathrm{CHCl}_{3}\right) ;{ }^{1} \mathrm{H}-\mathrm{NMR}(300 \mathrm{MHz}) \delta 0.04,0.05,0.07(3 \mathrm{~s}$, total $12 \mathrm{H})$, 0.86, $0.90(2 \mathrm{~s}, 9 \mathrm{H} \times 2), 0.94(\mathrm{~d}, J=6.6 \mathrm{~Hz}, 3 \mathrm{H}), 1.67,1.68(2 \mathrm{~s}, 3 \mathrm{H} \times 2), 1.55-1.81(\mathrm{~m}, 4 \mathrm{H}), 2.23-2.32(\mathrm{~m}, 4 \mathrm{H})$, $2.41(\mathrm{dd}, J=4.2,13.8 \mathrm{~Hz}, 1 \mathrm{H}), 3.80(\mathrm{~s}, 3 \mathrm{H}), 3.80(\mathrm{~m}, 1 \mathrm{H}), 3.99-4.09(\mathrm{~m}, 4 \mathrm{H}), 4.21,4.49(2 \mathrm{~d}, J=11.6 \mathrm{~Hz}$, $1 \mathrm{H} \times 2), 5.27(\mathrm{~s}, 1 \mathrm{H}), 5.30(\mathrm{t}, J=9.5 \mathrm{~Hz}, 1 \mathrm{H}), 5.52-5.73(\mathrm{~m}, 3 \mathrm{H}), 6.18-6.28(\mathrm{~m}, 2 \mathrm{H}), 6.86(\mathrm{~m}, 2 \mathrm{H}), 7.23(\mathrm{~m}$, $2 \mathrm{H}) ;{ }^{13} \mathrm{C}-\mathrm{NMR}(68 \mathrm{MHz}) \delta-4.70,-4.58,-4.44,-4.09,15.20,17.88,17.97,24.33,25.71 \times 4,25.83 \times 3,35.39$, $38.33,41.18,41.70,44.86,55.20,63.61,66.63,68.97,69.57,77.32,95.57,106.32,113.57 \times 2,128.06$, $129.27 \times 2,129.41,130.50,130.91,131.37,132.06,132.12,158.96,160.97,169.06$; IR (neat) 3500, 2930, 1730, 1640, 1615, $1515 \mathrm{~cm}^{-1}$; HRMS calcd for $\mathrm{C}_{39} \mathrm{H}_{64} \mathrm{O}_{7} \mathrm{Si}_{2}\left(\mathrm{M}^{+}\right.$-acetone) $\mathrm{m} / z$ 700.4191, found 700.4191 .

\section{$(2 E, 5 R, 6 S, 7 Z, 9 E, 12 R, 14 R)-12,14-B i s(t$-butyldimethylsilyloxy)-15-(2,2-dimethyl-1,3-dioxin-4-one-6-yl)-}

6-[(4-methoxyphenyl)methoxy]-5-methyl-2,7,9-pentadecatrienal (42)
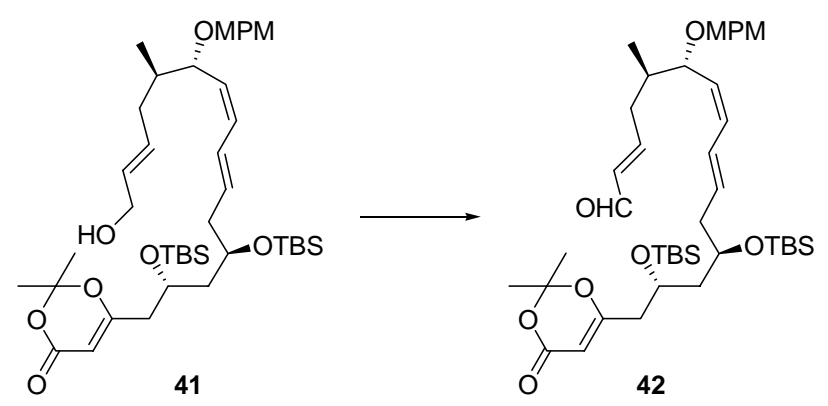

To a cooled $\left(0{ }^{\circ} \mathrm{C}\right)$, stirred solution of $41(55.6 \mathrm{mg}, 0.0732 \mathrm{mmol})$ in $\mathrm{CH}_{2} \mathrm{Cl}_{2}(1 \mathrm{~mL})$ was added $\mathrm{MnO}_{2}(278$ $\mathrm{mg}, 3.20 \mathrm{mmol}$ ). The mixture was stirred for $30 \mathrm{~min}$, and the insoluble materials were filtered off and washed well with $\mathrm{CH}_{2} \mathrm{Cl}_{2}$. The combined filtrate and washings were concentrated in vacuo. The residue was purified 
by column chromatography on silica gel (EtOAc/hexane, 1:4) to provide $49.5 \mathrm{mg}$ (89\%) of $\mathbf{4 2}$ as a colorless oil; TLC, $\mathrm{R}_{f} 0.55$ (EtOAc/hexane, 1:2); $[\alpha]^{23}{ }_{\mathrm{D}}-37.6$ (c 1.47, $\mathrm{CHCl}_{3}$ ); ${ }^{1} \mathrm{H}$ NMR (300 MHz) $\delta 0.05,0.07$ (2s, total $12 \mathrm{H}), 0.87,0.90(2 \mathrm{~s}, 9 \mathrm{H} \times 2), 0.97(\mathrm{~d}, J=6.6 \mathrm{~Hz}, 3 \mathrm{H}), 1.54-1.83(\mathrm{~m}, 8 \mathrm{H}), 1.90(\mathrm{~m}, 1 \mathrm{H}), 2.11(\mathrm{~m}, 1 \mathrm{H})$, 2.20-2.36 (m, 3H), $2.42(\mathrm{dd}, J=4.3,13.8 \mathrm{~Hz}, 1 \mathrm{H}), 2.55(\mathrm{~m}, 1 \mathrm{H}), 3.77-3.86(\mathrm{~m}, 4 \mathrm{H}), 4.05-4.14(\mathrm{~m}, 2 \mathrm{H})$, $4.21,4.51(2 \mathrm{~d}, J=11.7 \mathrm{~Hz}, 1 \mathrm{H} \times 2), 5.26-5.33(\mathrm{~m}, 2 \mathrm{H}), 5.72(\mathrm{dt}, J=7.6,13.6 \mathrm{~Hz}, 1 \mathrm{H}), 6.06(\mathrm{dd}, J=7.9$, $15.5 \mathrm{~Hz}, 1 \mathrm{H}), 6.13-6.17(\mathrm{~m}, 2 \mathrm{H}), 6.78(\mathrm{dt}, J=7.7,15.5 \mathrm{~Hz}, 1 \mathrm{H}), 6.87(\mathrm{~m}, 2 \mathrm{H}), 7.22(\mathrm{~m}, 2 \mathrm{H}), 9.46(\mathrm{~d}, J=7.9$ $\mathrm{Hz}, 1 \mathrm{H}) ;{ }^{13} \mathrm{C}$ NMR $(75 \mathrm{MHz}) \delta-4.72,-4.61,-4.46,-4.13,15.35,17.85,17.93,24.31,25.68 \times 3,25.78 \times 4$, $35.94,37.87,41.09,41.70,44.86,55.17,66.59,68.86,69.58,76.82,95.56,106.26,113.62 \times 2,127.65$, $128.27,129.29 \times 2,130.51,132.80,134.03 \times 2,157.65,159.03,160.86,168.97,193.79$; IR (neat) 2930, 1730, $1695,1620,1515 \mathrm{~cm}^{-1}$; HRMS calcd for $\mathrm{C}_{38} \mathrm{H}_{59} \mathrm{O}_{8} \mathrm{Si}_{2}\left(\mathrm{M}^{+}-t-\mathrm{Bu}\right) \mathrm{m} / z$ 699.3748, found 699.3734 .

\section{Intramolecular Diels-Alder rection of 42:}

$(1 S, 2 S, 3 S, 4 Z, 6 S, 7 S, 8 R)$-2-Formyl-7-[(4-methoxyphenyl)methoxy]-8-methyl-3-[(2R,4R)-7-butoxycarbonyl-2,4-bis(t-butyldimethylsilyloxy)-6-oxoheptyl]bicyclo[4.3.0]non-4-ene (10)

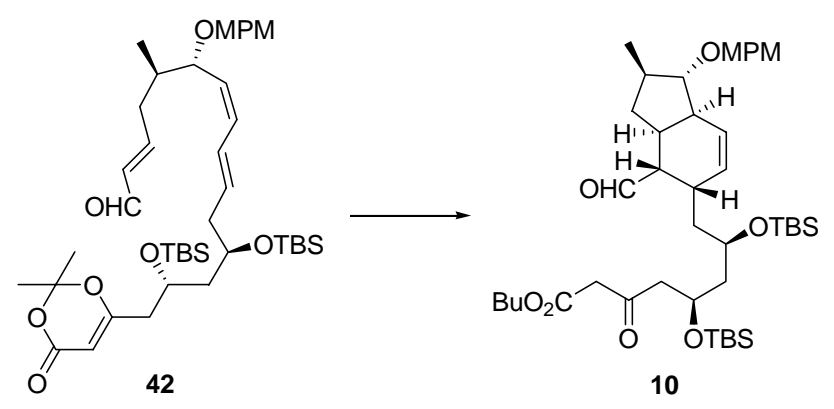

The compound $42(50.0 \mathrm{mg}, 0.0660 \mathrm{mmol})$ was dissolved in degassed 1-butanol $(3 \mathrm{~mL})$, and a crystal of BHT was added. The solution was transferred into a $20 \mathrm{~mL}$ sealed tube equipped with a screwed stopper, and the tube was filled with argon. The tube was heated to $150{ }^{\circ} \mathrm{C}$ for $6 \mathrm{~h}$. After being cooled to ambient temperature, the solution was concentrated in vacuo. The residue was purified by column chromatography on silica gel (EtOAc/hexane, 1:20 to $1: 8)$ to provide $33.5 \mathrm{mg}(66 \%)$ of $\mathbf{1 0}$ as a colorless oil; TLC, $\mathrm{R}_{f} 0.44$ (EtOAc/hexane, 1:5); $[\alpha]^{24}{ }_{\mathrm{D}}-43.0\left(c 1.26, \mathrm{CHCl}_{3}\right) ;{ }^{1} \mathrm{H}$ NMR $(300 \mathrm{MHz}$, keto/enol = 3:1) $\delta 0.03,0.06,0.06$ (3s, total 12H), $0.88(\mathrm{~s}, 18 \mathrm{H}), 0.93(\mathrm{t}, J=6.6 \mathrm{~Hz}, 3 \mathrm{H}), 1.05(\mathrm{~d}, J=6.0 \mathrm{~Hz}, 3 \mathrm{H}), 1.09(\mathrm{~m}, 1 \mathrm{H}), 1.34-1.50(\mathrm{~m}$, $3 \mathrm{H}), 1.53-1.75(\mathrm{~m}, 5 \mathrm{H}), 1.93-2.07(\mathrm{~m}, 2 \mathrm{H}), 2.31(\mathrm{~d}, J=6.0 \mathrm{~Hz}, 2 \mathrm{H} \times 1 / 4$, enol form), $2.41(\mathrm{~m}, 1 \mathrm{H})$, 2.61-2.76 (m, $3 \mathrm{H}+2 \mathrm{H} \times 3 / 4$, keto form), $3.16(\mathrm{~m}, 1 \mathrm{H}), 3.45(\mathrm{~s}, 2 \mathrm{H} \times 3 / 4$, keto form), 3.80, (s, $3 \mathrm{H}), 3.88$ (m, 1H), 4.07 (m, $1 \mathrm{H} \times 1 / 4$, enol form), $4.13(\mathrm{t}, J=6.6 \mathrm{~Hz}, 2 \mathrm{H}), 4.20(\mathrm{~m}, 1 \mathrm{H} \times 3 / 4$, keto form), 4.47, 4.56 (2d, $J=11.3 \mathrm{~Hz}, 1 \mathrm{H} \times 2), 4.99$ (s, $1 \mathrm{H} \times 1 / 4$, enol form), 5.73 (br d, $J=10.2 \mathrm{~Hz}, 1 \mathrm{H}), 5.81$ (br d, $J=10.2 \mathrm{~Hz}, 1 \mathrm{H})$, $6.88(\mathrm{~m}, 2 \mathrm{H}), 7.27(\mathrm{~m}, 2 \mathrm{H}), 9.72(\mathrm{~d}, J=2.1 \mathrm{~Hz}, 1 \mathrm{H}), 12.04\left(\mathrm{~s}, 1 \mathrm{H} \times 1 / 4\right.$, enol form); ${ }^{13} \mathrm{C} \mathrm{NMR}(75 \mathrm{MHz}$, keto + enol form) $\delta-4.57,-4.51,-4.48,-4.10,13.64,17.88,17.95,18.34,19.01,25.81 \times 3,25.84 \times 3,28.75$, $29.6730 .48,30.66$ (enol), 33.93, 36.80, 39.59, 43.56, 43.84 (enol), 45.68, 50.42, 50.76, 54.56, 54.71 (enol), 55.25, 63.84 (enol), 65.21, 65.98, 66.85, 72.10, 91.46 (enol), 92.22, $113.77 \times 2,128.60,129.21 \times 2,130.63$, 
130.71, 159.15, 167.01, 172.54 (enol), 175.04 (enol), 201.31, 204.83; IR (neat) 2950, 1720, 1615, $1515 \mathrm{~cm}^{-1}$; HRMS calcd for $\mathrm{C}_{43} \mathrm{H}_{72} \mathrm{O}_{8} \mathrm{Si}_{2}\left(\mathrm{M}^{+}\right) \mathrm{m} / z$ 772.4766, found 772.4749 .

\section{$(2 E, 5 R, 6 S, 7 Z, 9 E, 12 R)-12$-(t-Butyldimethysilyloxy)-1-(t-butyldiphenylsilyloxy)-13-[(6R)-4-methoxy-} methoxy-5,6-dihydropyran-2-one-6-yl]-6-[(4-methoxyphenyl)methoxy]-5-methyl-2,7,9-tridecatriene

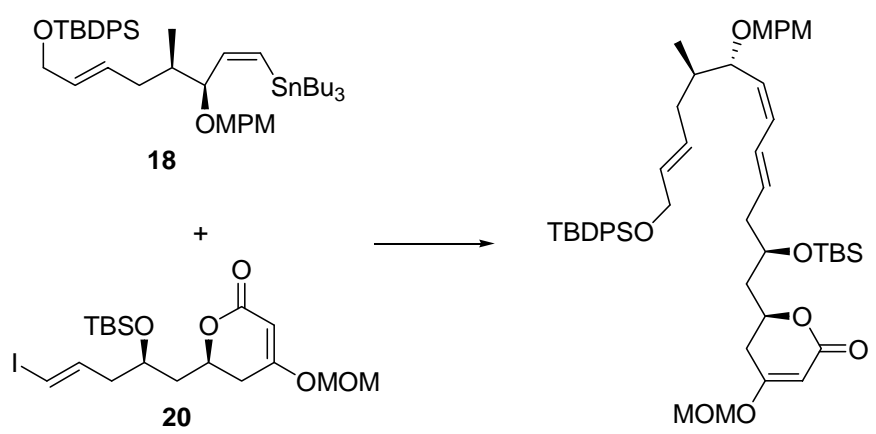

The following reaction was carried out under argon. To a stirred solution of $\mathbf{1 8}(991.1 \mathrm{mg}, 1.23 \mathrm{mmol})$ and $\mathbf{2 0}$ (396.6 $\mathrm{mg}, 0.822 \mathrm{mmol})$ in degassed DMSO $(15 \mathrm{~mL})$ were added $\mathrm{CuCl}(122 \mathrm{mg}, 1.23 \mathrm{mmol})$ and $\mathrm{PdCl}_{2}(\mathrm{MeCN})_{2}(21.3 \mathrm{mg}, 0.0822 \mathrm{mmol})$. The mixture was stirred for $10 \mathrm{~h}$ and then diluted with saturated brine-saturated aqueous $\mathrm{NaHCO}_{3}(1: 1,300 \mathrm{~mL})$. This was extracted with $\mathrm{Et}_{2} \mathrm{O}$. The combined organic layers were dried, concentrated in vacuo, and filtered through a short silica-gel column to give the crude triene, which was used in the next step without purification. In a small-scale experiment, the pure triene was obtained by column chromatography on silica gel (EtOAc/hexane, 1:2) as a colorless oil; TLC, $\mathrm{R}_{f} 0.69$ (acetone/toluene, 1:5); $[\alpha]^{23}{ }_{\mathrm{D}}-45.3\left(c \mathrm{1.24}, \mathrm{CHCl}_{3}\right) ;{ }^{1} \mathrm{H} \mathrm{NMR}(270 \mathrm{MHz}) \delta 0.05,0.06(2 \mathrm{~s}, 3 \mathrm{H} \times 2), 0.88(\mathrm{~s}$, 9H), $0.94(\mathrm{~d}, J=6.6 \mathrm{~Hz}, 3 \mathrm{H}), 1.04(\mathrm{~s}, 9 \mathrm{H}), 1.65-1.84(\mathrm{~m}, 3 \mathrm{H}), 2.03(\mathrm{~m}, 1 \mathrm{H}), 2.21-2.39$ (m, 4H), 2.51 (ddd, $J$ $=1.5,11.4,17.0 \mathrm{~Hz}, 1 \mathrm{H}), 3.44(\mathrm{~s}, 3 \mathrm{H}), 3.79(\mathrm{~s}, 3 \mathrm{H}), 3.95-4.05(\mathrm{~m}, 2 \mathrm{H}), 4.14(\mathrm{~m}, 2 \mathrm{H}), 4.22,4.49(2 \mathrm{~d}, J=11.7$ $\mathrm{Hz}, 1 \mathrm{H} \times 2), 4.55(\mathrm{~m}, 1 \mathrm{H}), 5.05,5.09(2 \mathrm{~d}, J=6.2 \mathrm{~Hz}, 1 \mathrm{H} \times 2), 5.26-5.33(\mathrm{~m}, 2 \mathrm{H}), 5.47-5.76(\mathrm{~m}, 3 \mathrm{H})$, 6.18-6.32 (m, 2H), $6.86(\mathrm{~m}, 2 \mathrm{H}), 7.24(\mathrm{~m}, 2 \mathrm{H}), 7.33-7.45(\mathrm{~m}, 6 \mathrm{H}), 7.66-7.70(\mathrm{~m}, 4 \mathrm{H}) ;{ }^{13} \mathrm{C} \mathrm{NMR}(68 \mathrm{MHz})$ $\delta-4.64,-4.29,15.17,18.00,19.21,25.80 \times 3,26.84 \times 3,33.09,35.45,38.47,40.23,41.55,55.23,57.04$, $64.53,68.22,69.66,72.97,77.75,93.24,94.42,113.63 \times 2,127.60 \times 4,128.23,129.24 \times 2,129.47,129.53$ $\times 3,130.27,131.05,131.97,132.15,133.87 \times 2,135.52 \times 4,158.96,166.90,169.50 ;$ IR (neat) 2930, 1715, $1610,1515 \mathrm{~cm}^{-1}$; HRMS calcd for $\mathrm{C}_{47} \mathrm{H}_{63} \mathrm{O}_{8} \mathrm{Si}_{2}\left(\mathrm{M}^{+}-t-\mathrm{Bu}\right) \mathrm{m} / z$ 811.4061, found 811.4062. 
$(2 E, 5 R, 6 S, 7 Z, 9 E, 12 R)-12-(t$-Butyldimethysilyloxy)-13-[(6R)-4-methoxymethoxy-5,6-dihydro-pyran-2one-6-yl]-6-[(4-methoxyphenyl)methoxy]-5-methyl-2,7,9-tridecatrien-1-ol (43)
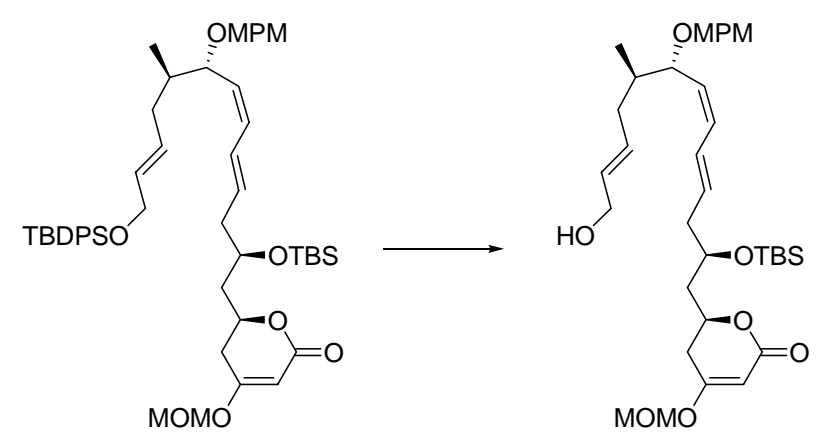

43

To a cooled $\left(0{ }^{\circ} \mathrm{C}\right)$, stirred solution of the TBDPS ether obtained above in pyridine-THF $(1: 2,20 \mathrm{~mL})$ was added HF-pyridine complex $(2 \mathrm{~mL})$. The mixture was stirred for $12 \mathrm{~h}$, and quenched with saturated aqueous $\mathrm{NaHCO}_{3}$. This was diluted with saturated aqueous $\mathrm{NaHCO}_{3}(50 \mathrm{~mL})$, and extracted with $\mathrm{CH}_{2} \mathrm{Cl}_{2}$. The combined organic layers were dried and concentrated in vacuo. The residue was purified by column chromatography on silica gel (acetone/toluene, 1:10) to provide $356 \mathrm{mg}(65 \%, 2$ steps) of $\mathbf{4 3}$ as a colorless oil; TLC, $\mathrm{R}_{f} 0.28$ (acetone/toluene, 1:5); $[\alpha]^{24}{ }_{\mathrm{D}}-44.4$ (c 1.40, $\mathrm{CHCl}_{3}$ ); ${ }^{1} \mathrm{H}$ NMR (300 MHz) $\delta 0.06,0.07$ (2s, $3 \mathrm{H} \times 2), 0.88(\mathrm{~s}, 9 \mathrm{H}), 0.96(\mathrm{~d}, J=6.8 \mathrm{~Hz}, 3 \mathrm{H}), 1.67$ (br s, 1H), 1.68-1.89 (m, 3H), $2.04(\mathrm{~m}, 1 \mathrm{H}), 2.19-2.41$ (m, 4H), $2.52(\mathrm{ddd}, J=1.5,11.6,17.2 \mathrm{~Hz}, 1 \mathrm{H}), 3.45$ (s, 3H), $3.80(\mathrm{~s}, 3 \mathrm{H}), 3.96-4.07$ (m, 4H), 4.21, 4.49 (2d, $J=11.4 \mathrm{~Hz}, 1 \mathrm{H} \times 2), 4.57(\mathrm{~m}, 1 \mathrm{H}), 5.06,5.10(2 \mathrm{~d}, J=6.1 \mathrm{~Hz}, 1 \mathrm{H} \times 2), 5.26-5.36(\mathrm{~m}, 2 \mathrm{H}), 5.52-5.76(\mathrm{~m}$, $3 \mathrm{H}), 6.18-6.32(\mathrm{~m}, 2 \mathrm{H}), 6.86(\mathrm{~m}, 2 \mathrm{H}), 7.23(\mathrm{~m}, 2 \mathrm{H}) ;{ }^{13} \mathrm{C} \mathrm{NMR}(68 \mathrm{MHz}) \delta-4.73,-4.38,15.17,17.94,25.74$ $\times 3,32.97,35.42,38.24,40.23,41.52,55.17,56.99,63.47,68.28,69.60,72.91,77.29,93.10,94.39,113.54$ $\times 2,128.20,129.24 \times 2,129.55,130.74,130.79,130.91,131.97,132.03,158.90,167.02,169.58$; IR (neat) $3450,2930,1715,1610,1515 \mathrm{~cm}^{-1}$; HRMS calcd for $\mathrm{C}_{35} \mathrm{H}_{54} \mathrm{O}_{8} \mathrm{Si}\left(\mathrm{M}^{+}\right) \mathrm{m} / z$ 630.3588, found 630.3587 .

$(2 E, 5 R, 6 S, 7 Z, 9 E, 12 R)-12$-( $t$-Butyldimethysilyloxy)-13-[(6R)-4-methoxymethoxy-5,6-dihydropyran-2one-6-yl]-6-[(4-methoxyphenyl)methoxy]-5-methyl-2,7,9-tridecatrienal (15)

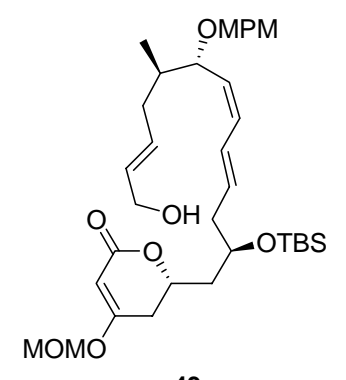

43

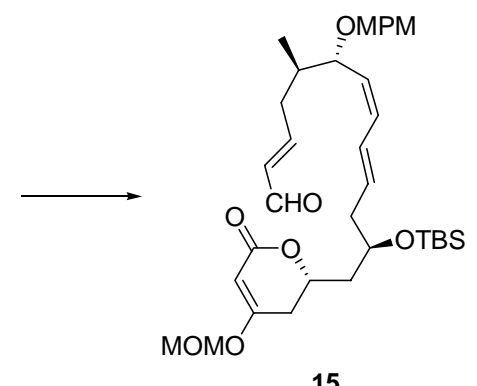

15

To a cooled $\left(0{ }^{\circ} \mathrm{C}\right)$, stirred solution of $\mathbf{4 3}(96.4 \mathrm{mg}, 0.153 \mathrm{mmol})$ in $\mathrm{CH}_{2} \mathrm{Cl}_{2}(2 \mathrm{~mL})$ was added $\mathrm{MnO}_{2}(482 \mathrm{mg}$, $5.54 \mathrm{mmol}$ ). The mixture was stirred for $30 \mathrm{~min}$, and the insoluble materials were filtered off and washed well with EtOH. The combined filtrate and washings were concentrated in vacuo. The residue was purified 
by column chromatography on silica gel (EtOAc/hexane, 1:4) to provide $90.4 \mathrm{mg}$ (94\%) of $\mathbf{1 5}$ as a colorless oil; TLC, $\mathrm{R}_{f} 0.52$ (EtOAc/hexane, 1:1); $[\alpha]^{24}{ }_{\mathrm{D}}-61.3$ (c 1.26, $\mathrm{CHCl}_{3}$ ); ${ }^{1} \mathrm{H}$ NMR (300 MHz) $\delta$ 0.06, 0.07 (2s, $3 \mathrm{H} \times 2), 0.88(\mathrm{~s}, 9 \mathrm{H}), 0.97(\mathrm{~d}, J=6.8 \mathrm{~Hz}, 3 \mathrm{H}), 1.76(\mathrm{dt}, J=14.1,5.9 \mathrm{~Hz}, 1 \mathrm{H}), 1.90(\mathrm{~m}, 1 \mathrm{H}), 2.01-2.18(\mathrm{~m}$, $2 \mathrm{H}), 2.25-2.44(\mathrm{~m}, 3 \mathrm{H}), 2.49-2.59(\mathrm{~m}, 2 \mathrm{H}), 3.46(\mathrm{~s}, 3 \mathrm{H}), 3.81(\mathrm{~s}, 3 \mathrm{H}), 3.97-4.11(\mathrm{~m}, 2 \mathrm{H}), 4.21,4.51(2 \mathrm{~d}, J=$ $11.5 \mathrm{~Hz}, 1 \mathrm{H} \times 2), 4.57(\mathrm{~m}, 1 \mathrm{H}), 5.06,5.11(2 \mathrm{~d}, J=6.1 \mathrm{~Hz}, 1 \mathrm{H} \times 2), 5.26-5.32(\mathrm{~m}, 2 \mathrm{H}), 5.75(\mathrm{~m}, 1 \mathrm{H}), 6.07$ $(\mathrm{dd}, J=8.1,15.6,1 \mathrm{H}), 6.20-6.31(\mathrm{~m}, 2 \mathrm{H}), 6.79(\mathrm{ddd}, J=6.6,8.1,15.6 \mathrm{~Hz}, 1 \mathrm{H}), 6.87(\mathrm{~m}, 2 \mathrm{H}), 7.22(\mathrm{~m}, 2 \mathrm{H})$, $9.47(\mathrm{~d}, J=7.8 \mathrm{~Hz}, 1 \mathrm{H}) ;{ }^{13} \mathrm{C} \mathrm{NMR}(68 \mathrm{MHz}) \delta-4.76,-4.43,15.26,17.88,25.69 \times 3,33.01,35.99,37.82$, $40.14,41.42,55.14,56.95,68.17,69.58,72.76,76.87,93.07,94.34,113.57 \times 2,127.75,128.34,129.24 \times 2$, $130.51,132.73 \times 2,133.98,157.75,158.97,166.77,169.46,193.86$; IR (neat) 2930, 1715, 1695, 1615, 1515 $\mathrm{cm}^{-1}$; HRMS calcd for $\mathrm{C}_{35} \mathrm{H}_{52} \mathrm{O}_{8} \mathrm{Si}\left(\mathrm{M}^{+}\right) \mathrm{m} / z$ 628.3431, found 628.3435 .

\section{Intramolecular Diels-Alder reaction of 15}

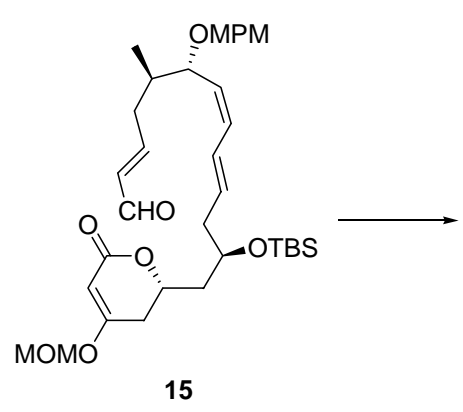

15

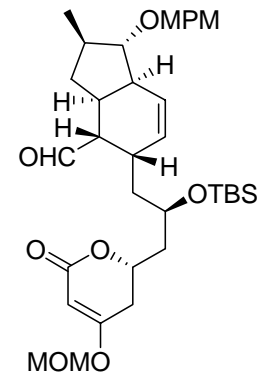

11

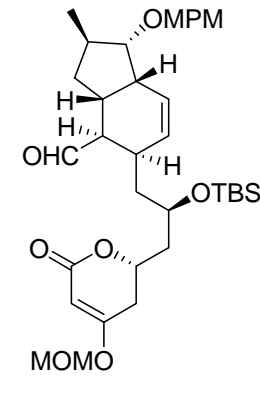

44

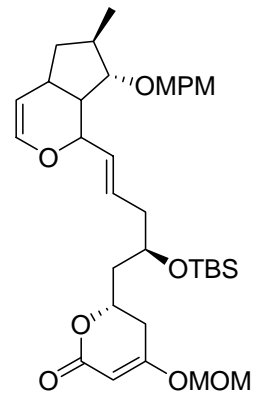

45

The compound $15(75.2 \mathrm{mg}, 0.0120 \mathrm{mmol})$ was dissolved in degassed toluene $(6 \mathrm{~mL})$, and a crystal of BHT was added. The solution was transferred into a $20 \mathrm{~mL}$ sealed tube equipped with a screwed stopper, and the tube was filled with argon. The tube was heated to $150{ }^{\circ} \mathrm{C}$ for $9 \mathrm{~h}$. After being cooled to ambient temperature, the solution was concentrated in vacuo. The residue was purified by column chromatography on silica gel (EtOAc/hexane, 1:5) to provide $61.2 \mathrm{mg}(81 \%)$ of 11, $4.2 \mathrm{mg}(5.6 \%)$ of $\mathbf{4 4}$, and $6.5 \mathrm{mg}(8.6 \%)$ of $\mathbf{4 5}$ as colorless oils; Compound 11: TLC, $\mathrm{R}_{f} 0.45$ (EtOAc/hexane, 1:1); $[\alpha]^{24}{ }_{\mathrm{D}}-2.1\left(c 0.970, \mathrm{CHCl}_{3}\right) ;{ }^{1} \mathrm{H}$ NMR (300 MHz) $\delta 0.06,0.08(2 \mathrm{~s}, 3 \mathrm{H} \times 2), 0.88(\mathrm{~s}, 9 \mathrm{H}), 1.05(\mathrm{~d}, J=5.9 \mathrm{~Hz}, 3 \mathrm{H}), 1.12(\mathrm{~m}, 1 \mathrm{H}), 1.46(\mathrm{~m}, 1 \mathrm{H}), 1.62-1.76$ $(\mathrm{m}, 2 \mathrm{H}), 1.93-2.12(\mathrm{~m}, 3 \mathrm{H}), 2.33-2.72(\mathrm{~m}, 6 \mathrm{H}), 3.17(\mathrm{dd}, J=4.3,6.7 \mathrm{~Hz}, 1 \mathrm{H}), 3.47(\mathrm{~s}, 3 \mathrm{H}), 3.81(\mathrm{~s}, 3 \mathrm{H})$, $4.09(\mathrm{~m}, 1 \mathrm{H}), 4.43-4.53(\mathrm{~m}, 2 \mathrm{H}), 4.56(\mathrm{~d}, J=11.2 \mathrm{~Hz}, 1 \mathrm{H}), 5.07,5.11(2 \mathrm{~d}, J=6.2 \mathrm{~Hz}, 1 \mathrm{H} \times 2), 5.32(\mathrm{~d}, J=$ $1.2 \mathrm{~Hz}, 1 \mathrm{H}), 5.73$ (br d, $J=10.1 \mathrm{~Hz}, 1 \mathrm{H}), 5.81$ (br d, $J=10.1 \mathrm{~Hz}, 1 \mathrm{H}), 6.88$ (m, 2H), 7.27 (m, 2H), 9.70 (d, $J$ $=2.7 \mathrm{~Hz}, 1 \mathrm{H}) ;{ }^{13} \mathrm{C}$ NMR $(75 \mathrm{MHz}) \delta-4.69,-4.23,17.86,18.29,25.73 \times 3,28.46,33.29,34.31,36.68,39.12$, $39.46,42.83,43.39,54.61,55.19,57.03,65.96,71.97,72.62,92.18,93.15,94.39,113.72 \times 2,127.93,129.18$ $\times 2,130.56,130.81,159.08,166.65,169.38,204.91$; IR (neat) $2930,1715,1615,1515 \mathrm{~cm}^{-1}$; HRMS calcd for $\mathrm{C}_{35} \mathrm{H}_{52} \mathrm{O}_{8} \mathrm{Si}\left(\mathrm{M}^{+}\right) \mathrm{m} / \mathrm{z}$ 628.3431, found 628.3425. Compound 44: TLC, $\mathrm{R}_{f} 0.46$ (EtOAc/hexane, 1:1); $[\alpha]^{22}{ }_{\mathrm{D}}$ -112 (c 0.245, $\left.\mathrm{CHCl}_{3}\right) ;{ }^{1} \mathrm{H}$ NMR $(300 \mathrm{MHz}) \delta 0.06,0.06(2 \mathrm{~s}, 3 \mathrm{H} \times 2), 0.87(\mathrm{~s}, 9 \mathrm{H}), 0.97(\mathrm{~d}, J=6.6 \mathrm{~Hz}, 3 \mathrm{H})$, $1.52-1.73(\mathrm{~m}, 4 \mathrm{H}), 1.80(\mathrm{dt}, J=14.6,5.5 \mathrm{~Hz}, 1 \mathrm{H}), 1.89-2.12(\mathrm{~m}, 2 \mathrm{H}), 2.37(\mathrm{dd}, J=4.0,17.3 \mathrm{~Hz}, 1 \mathrm{H})$, 
2.43-2.68 (m, 4H), $2.80(\mathrm{~m}, 1 \mathrm{H}), 3.43(\mathrm{~m}, 1 \mathrm{H}), 3.47(\mathrm{~s}, 3 \mathrm{H}), 3.81(\mathrm{~s}, 3 \mathrm{H}), 4.05(\mathrm{~m}, 1 \mathrm{H}), 4.45(\mathrm{~d}, J=11.2 \mathrm{~Hz}$, $1 \mathrm{H}), 4.48-4.62(\mathrm{~m}, 2 \mathrm{H}), 5.07,5.11(2 \mathrm{~d}, J=6.1 \mathrm{~Hz}, 1 \mathrm{H} \times 2), 5.32(\mathrm{~d}, J=1.5 \mathrm{~Hz}, 1 \mathrm{H}), 5.78-5.86(\mathrm{~m}, 2 \mathrm{H})$, $6.88(\mathrm{~m}, 2 \mathrm{H}), 7.26(\mathrm{~m}, 2 \mathrm{H}), 9.72(\mathrm{~d}, J=1.5 \mathrm{~Hz}, 1 \mathrm{H}) ;{ }^{13} \mathrm{C} \mathrm{NMR}(75 \mathrm{MHz}) \delta-4.38,-4.31,17.96,18.37,25.81$ $\times 3,29.00,31.94,33.26,34.25,36.37,38.46,39.20,41.53,54.09,55.27,57.11,67.08,71.47,72.61,87.38$, $93.25,94.47,113.75 \times 2,127.57,129.11 \times 2,130.71,131.15,159.12,166.72,169.43,205.06$; IR (neat) 2930, $1715,1615,1515 \mathrm{~cm}^{-1}$; HRMS calcd for $\mathrm{C}_{35} \mathrm{H}_{52} \mathrm{O}_{8} \mathrm{Si}\left(\mathrm{M}^{+}\right) \mathrm{m} / z$ 628.3431, found 628.3427. Compound 45 (ca. 3:2 mixture of dastereomers): TLC, $\mathrm{R}_{f} 0.55$ (EtOAc/hexane, 1:1); ${ }^{1} \mathrm{H} \mathrm{NMR}$ (300 MHz, signals for 2 diastereomers) $\delta 0.04,0.06,0.08(3 \mathrm{~s}$, total $6 \mathrm{H}), 0.87(\mathrm{~s}, 0.4 \times 9 \mathrm{H}), 0.88(\mathrm{~s}, 0.6 \times 9 \mathrm{H}), 1.11(\mathrm{~d}, J=7.1 \mathrm{~Hz}, 0.6$ $\times 3 \mathrm{H}), 1.14(\mathrm{~d}, J=6.8 \mathrm{~Hz}, 0.4 \times 3 \mathrm{H}), 1.42(\mathrm{~m}, 0.6 \mathrm{H}), 1.62-1.79(\mathrm{~m}, 2 \mathrm{H}), 1.93-2.55(\mathrm{~m}, 8 \mathrm{H}), 2.71(\mathrm{~m}, 0.4 \mathrm{H})$, $3.25(\mathrm{dd}, J=4.6,9.3 \mathrm{~Hz}, 0.4 \mathrm{H}), 3.46(\mathrm{~s}, 0.4 \times 3 \mathrm{H}), 3.47(\mathrm{~s}, 0.6 \times 3 \mathrm{H}), 3.66(\mathrm{dd}, J=5.0,8.1 \mathrm{~Hz}, 0.6 \mathrm{H}), 3.72$ $(\mathrm{m}, 0.4 \mathrm{H}), 3.79(\mathrm{~s}, 0.6 \times 3 \mathrm{H}), 3.80(\mathrm{~s}, 0.4 \times 3 \mathrm{H}), 3.95(\mathrm{~m}, 0.6 \mathrm{H}), 4.34-4.62(\mathrm{~m}, 4 \mathrm{H}), 4.72(\mathrm{~d}, J=6.1 \mathrm{~Hz}, 0.6$ $\mathrm{H}), 4.83(\mathrm{~m}, 0.4 \mathrm{H}), 5.04-5.12(\mathrm{~m}, 2 \mathrm{H}), 5.30(\mathrm{dd}, J=1.3,9.9 \mathrm{~Hz}, 1 \mathrm{H}), 5.47(\mathrm{dd}, J=15.4,6.1 \mathrm{~Hz}, 0.4 \mathrm{H})$, $5.64-5.76(\mathrm{~m}, 0.6 \times 2 \mathrm{H}+0.4 \mathrm{H}), 6.22(\mathrm{dd}, J=2.0,6.1 \mathrm{~Hz}, 0.6 \mathrm{H}), 6.30(\mathrm{dd}, J=1.6,6.0 \mathrm{~Hz}, 0.4 \mathrm{H}), 6.84-6.89$ $(\mathrm{m}, 2 \mathrm{H}), 7.25(\mathrm{~m}, 2 \mathrm{H}) ;{ }^{13} \mathrm{C}$ NMR (75 MHz, signals for 2 diastereomers) $\delta-4.71,-4.67,-4.34,-4.28,17.99$, 22.12, 22.37. $25.81 \times 3,28.59,29.69,32.88,33.00,33.06,34.08,36.06,37.70,39.18,39.40,39.89$, 40.00, $41.11,41.25,50.12,52.03,55.29,57.05,68.13,68.25,71.74,71.80,72.92,73.10,75.65,86.20,86.89,93.19$, $93.27,94.39,94.45,100.56,102.91,107.71,113.75,113.81,127.52,127.71,128.90129 .10,129.21,129.49$, 130.12, 130.71, 130.92, 131.79, 141.71, 142.63, 159.17, 166.90, 169.46, 169.51; IR (neat) 2930, 1715, 1615, $1515 \mathrm{~cm}^{-1}$; HRMS calcd for $\mathrm{C}_{35} \mathrm{H}_{52} \mathrm{O}_{8} \mathrm{Si}\left(\mathrm{M}^{+}\right) \mathrm{m} / z$ 628.3431, found 628.3435 .

\section{$(2 E, 5 R, 6 S, 7 Z, 9 E, 12 R, 14 R)-12,14-B i s(t$-butyldimethylsilyloxy)-15-(2,2-dimethyl-1,3-dioxin-4-one-6-yl)-}

1-(methoxycarbonyl)oxy-6-[(4-methoxyphenyl)methoxy]-5-methyl-2,7,9-pentadecatriene (46)
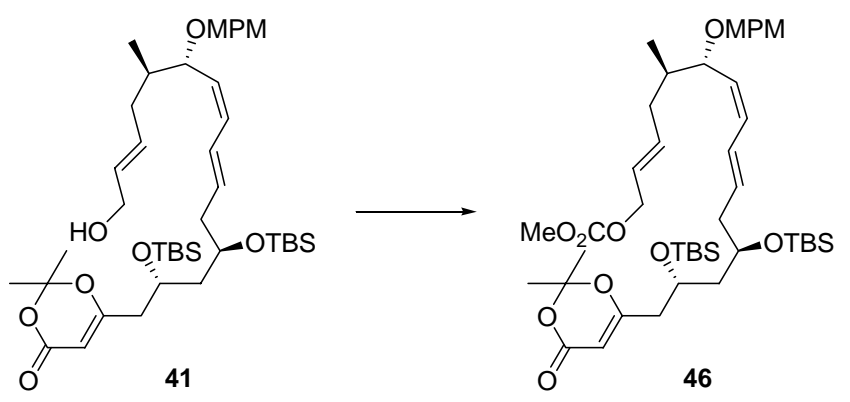

To a cooled $\left(0{ }^{\circ} \mathrm{C}\right)$, stirred solution of $\mathbf{4 1}(1.21 \mathrm{~g}, 1.59 \mathrm{mmol})$ in $\mathrm{CH}_{2} \mathrm{Cl}_{2}(24 \mathrm{~mL})$ were added pyridine $(0.70$ $\mathrm{mL}, 9.7 \mathrm{mmol})$ and methyl chloroformate $(0.40 \mathrm{~mL}, 5.1 \mathrm{mmol})$. The mixture was stirred for $2 \mathrm{~h}$, and this was concentrated in vacuo. The residue was purified by column chromatography on silica gel $\left(\mathrm{Et}_{3} \mathrm{~N} / \mathrm{hexane}, 1: 100\right.$ to EtOAc/hexane, 1:5) to provide $1.29 \mathrm{~g}$ (quant.) of $\mathbf{4 6}$ as a colorless oil; TLC, $\mathrm{R}_{f} 0.63$ (EtOAc/hexane, 1:1); $[\alpha]_{\mathrm{D}}^{25}-23.9\left(c \mathrm{1.77}, \mathrm{CHCl}_{3}\right) ;{ }^{1} \mathrm{H}-\mathrm{NMR}(270 \mathrm{MHz}) \delta 0.04,0.05,0.07$ (3s, total $\left.12 \mathrm{H}\right), 0.86,0.90(2 \mathrm{~s}, 9 \mathrm{H} \times 2)$, 
$0.92(\mathrm{~d}, J=6.6 \mathrm{~Hz}, 3 \mathrm{H}), 1.67,1.68(2 \mathrm{~s}, 3 \mathrm{H} \times 2), 1.54-1.83(\mathrm{~m}, 4 \mathrm{H}), 2.17-2.32(\mathrm{~m}, 4 \mathrm{H}), 2.43(\mathrm{dd}, J=4.4,13.9$ $\mathrm{Hz}, 1 \mathrm{H}), 3.77$ (s, 3H), $3.77(\mathrm{~m}, 1 \mathrm{H}), 3.80(\mathrm{~s}, 3 \mathrm{H}), 4.02(\mathrm{dd}, J=5.7,9.5 \mathrm{~Hz}, 1 \mathrm{H}), 4.10(\mathrm{~m}, 1 \mathrm{H}), 4.20,4.49(2 \mathrm{~d}$, $J=11.7 \mathrm{~Hz}, 1 \mathrm{H} \times 2), 4.54(\mathrm{~d}, J=6.2 \mathrm{~Hz}, 2 \mathrm{H}), 5.27(\mathrm{~s}, 1 \mathrm{H}), 5.28(\mathrm{t}, J=9.5 \mathrm{~Hz}, 1 \mathrm{H}), 5.53(\mathrm{dt}, J=15.0,6.2 \mathrm{~Hz}$, $1 \mathrm{H}), 5.63-5.78(\mathrm{~m}, 2 \mathrm{H}), 6.17-6.25(\mathrm{~m}, 2 \mathrm{H}), 6.86(\mathrm{~m}, 2 \mathrm{H}), 7.22(\mathrm{~m}, 2 \mathrm{H}) ;{ }^{13} \mathrm{C}-\mathrm{NMR}(68 \mathrm{MHz}) \delta-4.67,-4.55$, $-4.41,-4.06,15.15,17.91,18.00,24.36,25.74 \times 3,25.83 \times 4,35.45,38.21,41.18,41.75,44.92,54.65,55.23$, $66.63,68.53,69.00,69.60,77.29,95.63,106.32,113.63 \times 2,124.69,127.97,129.27 \times 3,130.88,132.23 \times 2$, 135.75, 155.64, 158.98, 160.97, 169.09; IR (neat) 2930, 1750, 1730, 1640, 1615, $1515 \mathrm{~cm}^{-1}$ : HRMS calcd for $\mathrm{C}_{40} \mathrm{H}_{63} \mathrm{O}_{10} \mathrm{Si}_{2}\left(\mathrm{M}^{+}-t-\mathrm{Bu}\right) \mathrm{m} / z$ 759.3960, found 759.3974 .

\section{Methyl (5R,7R,9E,11Z,13S,14R,16E)-5,7-Bis(t-butyldimethylsilyloxy)-18-(methoxycarbonyl)oxy-13- [(4-methoxyphenyl)methoxy]-14-methyl-3-oxo-9,11,16-octadecatriene-1-carboxylate (47a)}

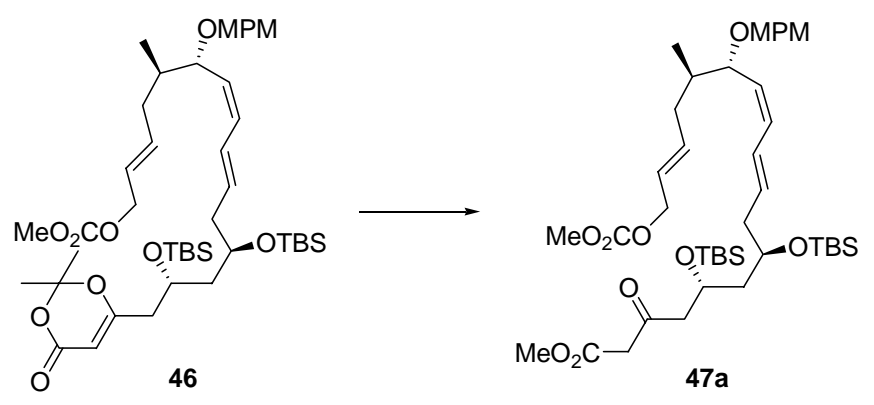

Compound 46 (1.29 g $1.59 \mathrm{mmol})$ was dissolved in degassed toluene-MeOH $(8: 1,25 \mathrm{~mL})$. The solution was transferred into three $20 \mathrm{~mL}$ sealed tubes equipped with a screwed stopper, and the tubes were filled with argon. The tubes were heated to $110^{\circ} \mathrm{C}$ for $3 \mathrm{~h}$. After being cooled to ambient temperature, the solution was concentrated in vacuo. The residue was purified by column chromatography on silica gel (EtOAc/hexane, 1:5) to provide $1.23 \mathrm{~g}(98 \%)$ of $\mathbf{4 7 a}$ as a colorless oil; TLC, $\mathrm{R}_{f} 0.74$ (EtOAc/hexane, 1:2); $[\alpha]^{26}{ }_{\mathrm{D}}-22.3(c 1.11$, $\left.\mathrm{CHCl}_{3}\right) ;{ }^{1} \mathrm{H}-\mathrm{NMR}(270 \mathrm{MHz}) \delta 0.03,0.05,0.06(3 \mathrm{~s}$, total $12 \mathrm{H}), 0.86,0.89(2 \mathrm{~s}, 9 \mathrm{H} \times 2), 0.92(\mathrm{~d}, J=6.7 \mathrm{~Hz}$, $3 \mathrm{H}), 1.52-1.86(\mathrm{~m}, 4 \mathrm{H}), 2.17-2.37$ ( $\mathrm{m}, 3 \mathrm{H}+2 \mathrm{H} \times 1 / 7$, enol form), 2.67-2.69 ( $\mathrm{m}, 2 \mathrm{H} \times 6 / 7$, keto form), 3.48 (s, $2 \mathrm{H} \times 6 / 7$, keto form), $3.72(\mathrm{~s}, 3 \mathrm{H}), 3.77(\mathrm{~s}, 3 \mathrm{H}), 3.78(\mathrm{~m}, 1 \mathrm{H}), 3.80(\mathrm{~s}, 3 \mathrm{H}), 4.01(\mathrm{dd}, J=5.5,9.2 \mathrm{~Hz}, 1 \mathrm{H})$, $4.21,4.49(2 \mathrm{~d}, J=11.6 \mathrm{~Hz}, 1 \mathrm{H} \times 2), 4.28(\mathrm{~m}, 1 \mathrm{H}), 4.55(\mathrm{~d}, J=6.1 \mathrm{~Hz}, 2 \mathrm{H}), 5.01(\mathrm{~s}, 1 \mathrm{H} \times 1 / 7$, enol form), $5.29(\mathrm{t}, J=9.2 \mathrm{~Hz}, 1 \mathrm{H}), 5.51(\mathrm{dt}, J=15.3,6.1 \mathrm{~Hz}, 1 \mathrm{H}), 5.65-5.79(\mathrm{~m}, 2 \mathrm{H}), 6.21-6.25(\mathrm{~m}, 2 \mathrm{H}), 6.86(\mathrm{~m}, 2 \mathrm{H})$, $7.23(\mathrm{~m}, 2 \mathrm{H}), 11.94\left(\mathrm{~s}, 1 \mathrm{H} \times 1 / 7\right.$, enol form); ${ }^{13} \mathrm{C}-\mathrm{NMR}(68 \mathrm{MHz}$, keto + enol form) $\delta-4.81,-4.52 \times 2,-4.21$, $15.17,17.88,17.97,25.83 \times 6,35.48,38.21,40.92,43.57$ (enol), 44.78, 45.09 (enol), 50.05, 50.68, 51.08 (enol), 52.21, 54.65, 55.23, 66.49, 67.01 (enol), 68.56, 68.91, 69.56, 77.29, 91.17 (enol), 113.60×2, 124.63, 127.74 (enol), 127.86, 128.92 (enol), 129.01, 129.30×2, 130.97, 132.43, 132.55, 132.78 (enol), 135.80, 155.64, 158.98, 167.45, 172.81 (enol), 175.66 (enol), 201.60; IR (neat) 2930, 1750, 1615, $1515 \mathrm{~cm}^{-1}$; HRMS (FAB) calcd for $\mathrm{C}_{42} \mathrm{H}_{70} \mathrm{O}_{10} \mathrm{Si}_{2} \mathrm{Na}\left(\mathrm{M}^{+}+\mathrm{Na}\right) \mathrm{m} / z$ 813.4406, found 813.4416. 
$(2 R S, 4 E, 7 R, 8 S, 9 Z, 11 E, 14 R, 16 R)-14,16$-Bis(t-butyldimethylsilyloxy)-2-methoxycarbonyl-8-[(4-methoxyphenyl)methoxy]-7-methyl-4,9,11-cycloheptadecatrien-1-one (48a, ca. 3:2 diastereomeric mixture)

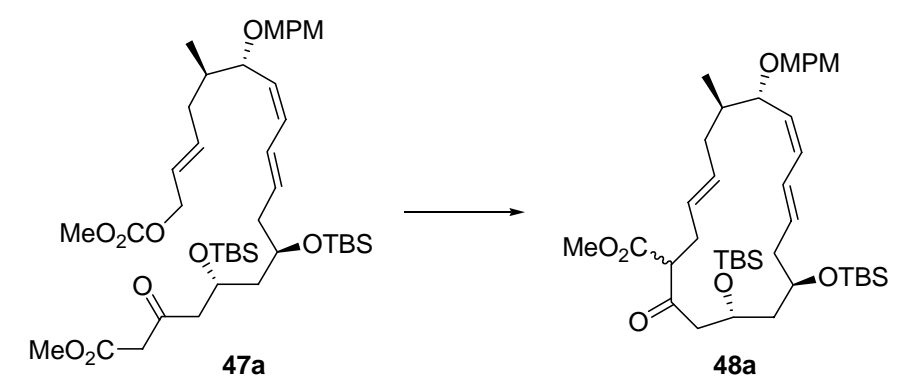

To a stirred solution of $\mathrm{Pd}\left(\mathrm{PPh}_{3}\right)_{4}(113 \mathrm{mg}, 0.0976 \mathrm{mmol})$ and 1,2-bis(diphenylphosphino)ethane (40.1 mg, $0.101 \mathrm{mmol})$ in THF $(100 \mathrm{~mL})$ was added a solution of $47 \mathbf{a}(400 \mathrm{mg}, 0.489 \mathrm{mmol})$ in THF $(80 \mathrm{~mL})$ over $1 \mathrm{~h}$. The mixture was stirred for $21 \mathrm{~h}$, and then concentrated in vacuo. The residue was purified by column chromatography on silica gel (EtOAc/hexane, 1:50 to 1:15) to provide $293 \mathrm{mg}$ (84\%) of 48a as a colorless oil; TLC, $\mathrm{R}_{f} 0.66$ (EtOAc/hexane, 1:4); $[\alpha]^{24}{ }_{\mathrm{D}}+28.8\left(c \mathrm{1.48}, \mathrm{CHCl}_{3}\right) ;{ }^{1} \mathrm{H}-\mathrm{NMR}(270 \mathrm{MHz}) \delta-0.03,0.03$, 0.05, 0.06, $0.07(5 \mathrm{~s}$, total $12 \mathrm{H}), 0.86,0.87,0.89,0.90(4 \mathrm{~s}$, total $18 \mathrm{H}), 0.95,0.98(2 \mathrm{~d}, J=6.7 \mathrm{~Hz}$, total $3 \mathrm{H})$, 1.43-1.76 (m, 3H), $1.89(\mathrm{~m}, 1 \mathrm{H}), 2.14(\mathrm{~m}, 1 \mathrm{H}), 2.31-2.46(\mathrm{~m}, 3 \mathrm{H}), 2.46-2.80(\mathrm{~m}, 3 \mathrm{H}), 3.49(\mathrm{~m}, 1 \mathrm{H}) 3.70$, $3.73(2 \mathrm{~s}$, total $3 \mathrm{H}), 3.81(\mathrm{~s}, 3 \mathrm{H}), 3.87(\mathrm{~m}, 1 \mathrm{H}), 4.03(\mathrm{dd}, J=5.2,8.9 \mathrm{~Hz}, 1 \mathrm{H} \times 3 / 5), 4.18,4.22(2 \mathrm{~d}, J=11.6$ $\mathrm{Hz}$, total $1 \mathrm{H}), 4.20-4.29(\mathrm{~m}, 1 \mathrm{H}+1 \mathrm{H} \times 2 / 5), 4.49,4.50(2 \mathrm{~d}, J=11.6 \mathrm{~Hz}$, total $1 \mathrm{H}), 5.22(\mathrm{~m}, 1 \mathrm{H}), 5.34-5.48$ $(\mathrm{m}, 2 \mathrm{H}), 5.76(\mathrm{~m}, 1 \mathrm{H}), 6.11-6.26(\mathrm{~m}, 1 \mathrm{H}+1 \mathrm{H} \times 3 / 5), 6.48(\mathrm{dd}, J=11.3,15.0 \mathrm{~Hz}, 1 \mathrm{H} \times 2 / 5), 6.88(\mathrm{~m}, 2 \mathrm{H})$, 7.25 (m, 2H); ${ }^{13} \mathrm{C}-\mathrm{NMR}$ (68 MHz, signals for 2 diastereomers) $\delta-4.67,-4.61,-4.52,-4.35,14.80,15.92$, 17.82, 17.91, 18.00, 18.14, 25.74, 25.80, 25.89, 30.72, 30.78, 36.34, 36.86, 38.56, 39.65, 39.74, 42.04, 44.32, $46.97,50.39,50.85,52.35,52.41,55.20,55.26,57.65,58.37,65.05,65.86,68.88,69.08,69.48,69.80,74.01$, $75.30,113.63,126.65,127.57,128.00,128.09,129.30,129.38,130.79,130.85,131.08,131.20,131.25$, 131.31, 132.03, 132.12, 132.23, 133.24, 158.96, 169.44, 169.75, 202.35, 202.76; IR (neat) 2930, 1750, 1650, $1615,1585,1515 \mathrm{~cm}^{-1}$; HRMS calcd for $\mathrm{C}_{40} \mathrm{H}_{66} \mathrm{O}_{7} \mathrm{Si}_{2}\left(\mathrm{M}^{+}\right) \mathrm{m} / z$ 714.4347, found 714.4342.

$(2 Z, 4 E, 7 R, 8 S, 9 Z, 11 E, 14 R, 16 R)-14,16-B$ is $(t$-butyldimethylsilyloxy)-2-methoxycarbonyl-8-[(4-methoxyphenyl)methoxy]-7-methyl-2,4,9,11-cycloheptadecatetraen-1-one (16)

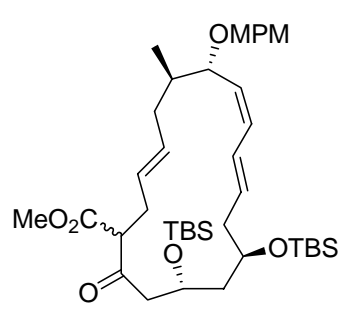

$48 a$

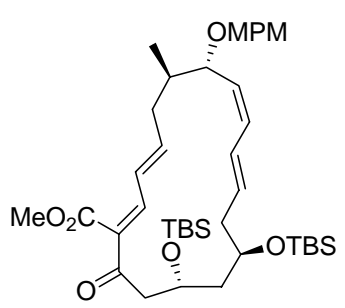

16 
The following reaction was carried out under argon. To a cooled $\left(-78{ }^{\circ} \mathrm{C}\right)$ stirred solution of $48 \mathbf{a}(113.2 \mathrm{mg}$, $0.158 \mathrm{mmol})$ in THF $(2.5 \mathrm{~mL})$ was added NaHMDS (1.0 M in THF, $0.32 \mathrm{~mL}, 0.32 \mathrm{mmol})$. The mixture was stirred for $1 \mathrm{~h}$ at $-78{ }^{\circ} \mathrm{C}$, and a solution of $\mathrm{PhSeCl}(83.3 \mathrm{mg}, 0.413 \mathrm{mmol})$ in toluene $(1.2 \mathrm{~mL})$ was added. After being stirred at $-78{ }^{\circ} \mathrm{C}$ for $5 \mathrm{~h}$, the solution was quenched with saturated aqueous $\mathrm{NH}_{4} \mathrm{Cl}$. This was diluted with saturated aqueous $\mathrm{NH}_{4} \mathrm{Cl}(10 \mathrm{~mL})$, and extracted with $\mathrm{CH}_{2} \mathrm{Cl}_{2}$. The combined organic layers were dried and concentrated in vacuo. The residue was purified by column chromatography on silica gel (toluene/hexane, 1:3 to toluene) to provide $123.0 \mathrm{mg}(89 \%)$ of the selenide as a colorless oil.

The following reaction was carried out under argon. To a cooled $\left(-78^{\circ} \mathrm{C}\right)$, stirred solution of the selenide (123.0 mg, $0.141 \mathrm{mmol})$ in $\mathrm{CH}_{2} \mathrm{Cl}_{2}(2.5 \mathrm{~mL})$ was added a solution of mCPBA (50.3 $\left.\mathrm{mg}, 0.291 \mathrm{mmol}\right)$ in $\mathrm{CH}_{2} \mathrm{Cl}_{2}(2 \mathrm{~mL})$. The mixture was stirred for $1 \mathrm{~h}$ at $-78{ }^{\circ} \mathrm{C}$, and quenched with $20 \%$ aqueous $\mathrm{Na}_{2} \mathrm{~S}_{2} \mathrm{O}_{3}$ and $\mathrm{MeOH}$. This was diluted with $20 \%$ aqueous $\mathrm{Na}_{2} \mathrm{~S}_{2} \mathrm{O}_{3}(20 \mathrm{~mL})$, and extracted with $\mathrm{CH}_{2} \mathrm{Cl}_{2}$. The combined organic layers were dried and concentrated in vacuo. The residue was purified by column chromatography on silica gel (EtOAc/toluene, 1:100) to provide $61.9 \mathrm{mg}(66 \%)$ of $\mathbf{1 6}$ as a colorless oil; TLC, $\mathrm{R}_{f} 0.28$ (EtOAc/hexane, 1:5); $[\alpha]^{24}{ }_{\mathrm{D}}-15.2\left(c 1.19, \mathrm{CHCl}_{3}\right) ;{ }^{1} \mathrm{H}-\mathrm{NMR}(270 \mathrm{MHz}) \delta 0.063,0.080$ (2s, total 12H), 0.88, $0.89(2 \mathrm{~s}, 9 \mathrm{H} \times 2), 1.17(\mathrm{~d}, J=6.8 \mathrm{~Hz}, 3 \mathrm{H}), 1.71(\mathrm{~m}, 2 \mathrm{H}), 1.90(\mathrm{~m}, 1 \mathrm{H}), 2.19-2.49(\mathrm{~m}, 4 \mathrm{H}), 2.86(\mathrm{dd}, J=7.6$, $12.9 \mathrm{~Hz}, 1 \mathrm{H}), 2.94(\mathrm{dd}, J=5.6,12.9 \mathrm{~Hz}, 1 \mathrm{H}), 3.77-3.86(\mathrm{~m}, 1 \mathrm{H}), 3.80(\mathrm{~s}, 3 \mathrm{H}), 3.82(\mathrm{~s}, 3 \mathrm{H}), 3.86(\mathrm{dd}, J=8.3$, $10.0 \mathrm{~Hz}, 1 \mathrm{H}), 4.18(\mathrm{~d}, J=11.7 \mathrm{~Hz}, 1 \mathrm{H}), 4.24(\mathrm{~m}, 1 \mathrm{H}), 4.47(\mathrm{~d}, J=11.7 \mathrm{~Hz}, 1 \mathrm{H}), 5.27(\mathrm{t}, J=10.0 \mathrm{~Hz}, 1 \mathrm{H})$, $5.73(\mathrm{ddd}, J=6.4,9.8,14.4 \mathrm{~Hz}, 1 \mathrm{H}), 6.12-6.28(\mathrm{~m}, 3 \mathrm{H}), 6.54(\mathrm{dd}, J=11.2,14.9 \mathrm{~Hz}, 1 \mathrm{H}), 6.86(\mathrm{~m}, 2 \mathrm{H}), 7.07$ $(\mathrm{d}, J=11.2 \mathrm{~Hz}, 1 \mathrm{H}), 7.23(\mathrm{~m}, 2 \mathrm{H}) ;{ }^{13} \mathrm{C}-\mathrm{NMR}(75 \mathrm{MHz}) \delta-4.74,-4.49,-4.44 \times 2,17.07,18.01 \times 2,25.89 \times 6$, $36.94,37.52,42.83,43.97,47.21,51.93,55.20,67.33,69.42,69.47,76.46,113.68 \times 2,127.80,128.22$, $129.05,129.28 \times 2,130.82,132.47,132.76,133.26,146.37,146.89,159.07,165.91,198.04$; IR (neat) 2930, 1730, 1690, 1630, 1585, $1515 \mathrm{~cm}^{-1}$; HRMS calcd for $\mathrm{C}_{40} \mathrm{H}_{64} \mathrm{O}_{7} \mathrm{Si}_{2}\left(\mathrm{M}^{+}\right) \mathrm{m} / z$. 712.4191, found 712.4187.

\section{Intramolecular Diels-Alder reaction of 16}

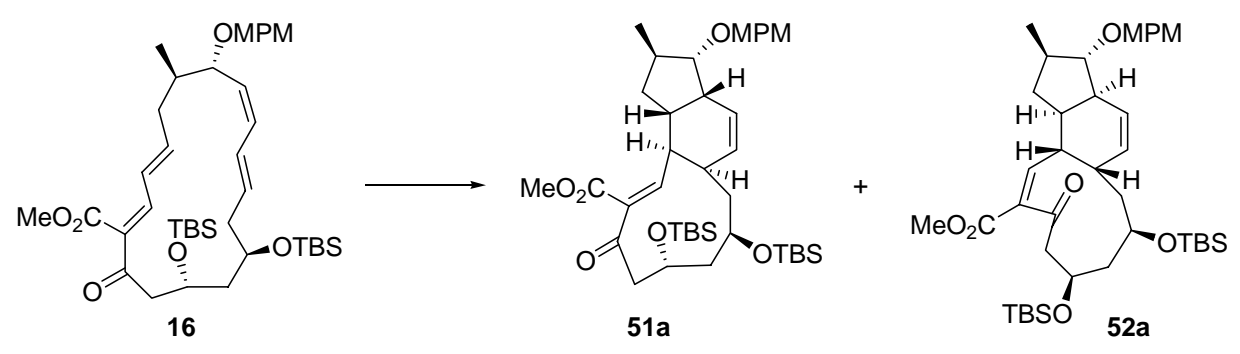

Compound 16 (30.2 mg, $0.0424 \mathrm{mmol})$ was dissolved in degassed toluene (6 mL), and a crystal of BHT was added. The solution was transferred into a $20 \mathrm{~mL}$ sealed tube equipped with a screwed stopper, and the tube was filled with argon. The tube was heated to $130{ }^{\circ} \mathrm{C}$ for $72.5 \mathrm{~h}$. After being cooled to ambient temperature, the solution was concentrated in vacuo. The residue was purified by column chromatography on silica gel 
(EtOAc/toluene, 1:150 to 1:50) to provide $8.7 \mathrm{mg}$ (29\%) of 51a as a colorless oil and $3.3 \mathrm{mg}(10 \%)$ of $\mathbf{5 2 a}$ as a colorless oil; Compound 51a: TLC, $\mathrm{R}_{f} 0.54$ (EtOAc/hexane, 1:3); $[\alpha]^{22}{ }_{\mathrm{D}}-62\left(\mathrm{c} 0.28, \mathrm{CHCl}_{3}\right) ;{ }^{1} \mathrm{H}-\mathrm{NMR}$ $(300 \mathrm{MHz}) \delta 0.0024,0.037,0.084,0.096(4 \mathrm{~s}, 3 \mathrm{H} \times 4), 0.86,0.88(2 \mathrm{~s}, 9 \mathrm{H} \times 2), 0.97(\mathrm{~d}, J=6.8 \mathrm{~Hz}, 3 \mathrm{H}), 1.46$ $(\mathrm{m}, 1 \mathrm{H}) 1.58-1.67(\mathrm{~m}, 2 \mathrm{H}), 1.82(\mathrm{~m}, 1 \mathrm{H}), 1.97-2.12(\mathrm{~m}, 3 \mathrm{H}), 2.22(\mathrm{~m}, 1 \mathrm{H}), 2.70(\mathrm{~m}, 2 \mathrm{H}), 2.79(\mathrm{dd}, J=2.6$, $12.8 \mathrm{~Hz}, 1 \mathrm{H}), 3.06(\mathrm{dd}, J=9.6,12.8 \mathrm{~Hz}, 1 \mathrm{H}), 3.14(\mathrm{~m}, 1 \mathrm{H}), 3.45(\mathrm{t}, J=5.6 \mathrm{~Hz}, 1 \mathrm{H}), 3.74-3.90$ (m, 2H), 3.74 (s, 3H), $3.81(\mathrm{~s}, 3 \mathrm{H}), 4.43(\mathrm{~d}, J=11.7 \mathrm{~Hz}, 1 \mathrm{H}), 4.51(\mathrm{~d}, J=11.7 \mathrm{~Hz}, 1 \mathrm{H}), 5.76(\mathrm{br} \mathrm{d}, J=9.3 \mathrm{~Hz}, 1 \mathrm{H}), 5.85$ (br d, $J=9.3 \mathrm{~Hz}, 1 \mathrm{H}), 6.74(\mathrm{~d}, J=11.0 \mathrm{~Hz}, 1 \mathrm{H}), 6.88(\mathrm{~m}, 2 \mathrm{H}), 7.25(\mathrm{~m}, 2 \mathrm{H}) ;{ }^{13} \mathrm{C}-\mathrm{NMR}(68 \mathrm{MHz}) \delta-4.75 \times 2$, $-4.50 \times 2,17.68,17.97,19.21,25.74 \times 3,25.83 \times 3,35.50,36.11,37.00,37.15,40.17,41.93,42.33,50.28$, $50.91,52.09,55.26,69.00,70.09,71.18,87.28,113.69 \times 2,125.09,128.89 \times 2,130.97,132.09,137.91$, 154.92, 158.05, 165.75, 197.00; IR (neat) 2930, 1730, 1705, 1670, 1615, $1515 \mathrm{~cm}^{-1}$; HRMS calcd for $\mathrm{C}_{40} \mathrm{H}_{64} \mathrm{O}_{7} \mathrm{Si}_{2}\left(\mathrm{M}^{+}\right) \mathrm{m} / z$ 712.4191, found 712.4202. Compound 33: TLC, $\mathrm{R}_{f} 0.54$ (EtOAc/hexane, 1:3); $[\alpha]^{27}{ }_{D}$ $-70\left(\mathrm{c} 0.13, \mathrm{CHCl}_{3}\right) ;{ }^{1} \mathrm{H}-\mathrm{NMR}\left(300 \mathrm{MHz}, \mathrm{CDCl}_{3}\right) \delta 0.012,0.015,0.025$ (3s, total $\left.12 \mathrm{H}\right), 0.86,0.87(2 \mathrm{~s}, 9 \mathrm{H}$ $\times 2), 1.05(\mathrm{~d}, J=6.8 \mathrm{~Hz}, 3 \mathrm{H}), 1.25(\mathrm{~m}, 1 \mathrm{H}) 1.50-1.74(\mathrm{~m}, 4 \mathrm{H}), 1.82(\mathrm{~m}, 1 \mathrm{H}), 1.94(\mathrm{~m}, 1 \mathrm{H}), 2.26(\mathrm{~m}, 1 \mathrm{H})$, $2.56(\mathrm{dd}, J=12.0,13.7 \mathrm{~Hz}, 1 \mathrm{H}), 2.60(\mathrm{~m}, 1 \mathrm{H}), 2.80-2.83(\mathrm{~m}, 2 \mathrm{H}), 3.15(\mathrm{dd}, J=3.7,13.7 \mathrm{~Hz}, 1 \mathrm{H}), 3.24(\mathrm{dd}, J$ $=2.4,6.1 \mathrm{~Hz}, 1 \mathrm{H}), 3.79(\mathrm{~s}, 3 \mathrm{H}), 3.80(\mathrm{~s}, 3 \mathrm{H}), 3.94-4.01(\mathrm{~m}, 2 \mathrm{H}), 4.40(\mathrm{~d}, J=11.2 \mathrm{~Hz}, 1 \mathrm{H}), 4.53(\mathrm{~d}, J=11.2$ $\mathrm{Hz}, 1 \mathrm{H}), 5.15$ (br d, $J=10.1 \mathrm{~Hz}, 1 \mathrm{H}), 5.63(\mathrm{br} \mathrm{d}, J=10.1 \mathrm{~Hz}, 1 \mathrm{H}), 6.88(\mathrm{~m}, 2 \mathrm{H}), 6.94$ (d, $J=12.2 \mathrm{~Hz}, 1 \mathrm{H})$, $7.26(\mathrm{~m}, 2 \mathrm{H}) ;{ }^{13} \mathrm{C}-\mathrm{NMR}(75 \mathrm{MHz}) \delta-4.97 \times 2,-4.82,-4.67,17.76,18.08,18.93,25.59 \times 3,25.78 \times 3,27.47$, $36.14,37.60,39.53,40.05,40.53,41.76,45.52,52.21,53.51,55.27,66.23,67.80,71.14,92.18,113.78 \times 2$, $129.16 \times 2,129.82,130.15,130.69,135.10,149.36,159.08,164.17,202.25$; IR (neat) 2930, 1730, 1705, 1615, $1515 \mathrm{~cm}^{-1}$; HRMS calcd for $\mathrm{C}_{40} \mathrm{H}_{64} \mathrm{O}_{7} \mathrm{Si}_{2}\left(\mathrm{M}^{+}\right) \mathrm{m} / z$ 712.4191, found 712.4200.

\section{$(1 S, 2 E, 6 R, 8 R, 10 S, 11 Z, 13 S, 14 S, 15 R, 17 R)-6,8-B$ is $(t$-butyldimethylsilyloxy)-3-hydroxymethyl-14-[(4- methoxyphenyl)methoxy]-15-methyltricyclo[8.7.0.0 $\left.{ }^{13,17}\right]$ heptadeca-2,11-dien-4-ol}
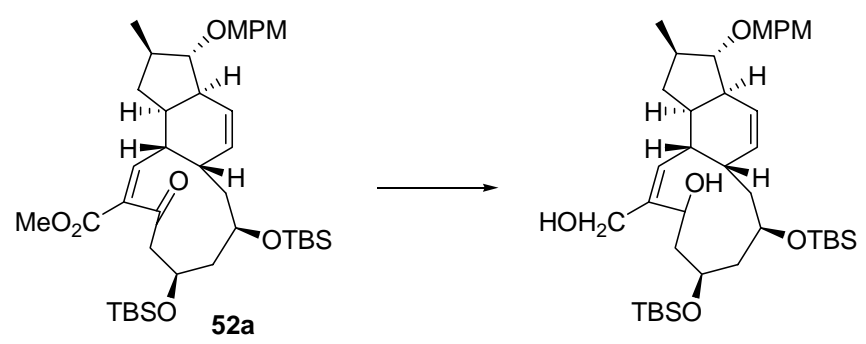

The following reaction was carried out under argon. To a cooled $\left(-78{ }^{\circ} \mathrm{C}\right)$, stirred solution of $\mathbf{5 2 a}(1.2 \mathrm{mg}$, $0.0017 \mathrm{mmol})$ in $\mathrm{CH}_{2} \mathrm{Cl}_{2}(1 \mathrm{~mL})$ was added Dibal-H (1.0 M solution in toluene, 2 drops). The mixture was stirred at $-78{ }^{\circ} \mathrm{C}$ for $1.5 \mathrm{~h}$ and then Dibal-H (1.0 M solution in toluene, 3 drops) was added. This was stirred at $-78{ }^{\circ} \mathrm{C}$ for $1 \mathrm{~h}$ and then Dibal-H (1.0 M solution in toluene, 3 drops) was added. This was stirred at $-78{ }^{\circ} \mathrm{C}$ for $1.5 \mathrm{~h}$ and quenched with $10 \%$ aqueous potassium sodium (+)-tartarate tetrahydrate. This was diluted with 
$10 \%$ aqueous solution potassium sodium (+)-tartarate tetrahydrate $(10 \mathrm{~mL})$, and extracted with $\mathrm{CH}_{2} \mathrm{Cl}_{2}$. The combined organic layers were dried and concentrated in vacuo. The residue was purified by column chromatography on silica gel (EtOAc/hexane, 1:3) to provide $1.2 \mathrm{mg}$ (quant.) of the diol as a colorless oil; TLC, $\mathrm{R}_{f} 0.46$ (EtOAc/hexane, 1:1); $[\alpha]^{27}{ }_{\mathrm{D}}-9.6\left(c 0.080, \mathrm{CHCl}_{3}\right) ;{ }^{1} \mathrm{H}-\mathrm{NMR}(300 \mathrm{MHz}) \delta-0.02-0.01,0.02$, $0.04(4 \mathrm{~s}, 3 \mathrm{H} \times 4), 0.86,0.87(2 \mathrm{~s}, 9 \mathrm{H} \times 2), 1.06(\mathrm{~d}, J=6.6 \mathrm{~Hz}, 3 \mathrm{H}), 1.25(\mathrm{~m}, 1 \mathrm{H}) 1.58-2.05(\mathrm{~m}, 7 \mathrm{H}), 2.20(\mathrm{~m}$, $1 \mathrm{H}), 2.59(\mathrm{~m}, 1 \mathrm{H}), 2.65(\mathrm{t}, J=13.9 \mathrm{~Hz}, 1 \mathrm{H}), 2.82(\mathrm{~m}, 1 \mathrm{H}), 3.26(\mathrm{dd}, J=2.2,6.5 \mathrm{~Hz}, 1 \mathrm{H}), 3.61(\mathrm{~m}, 1 \mathrm{H}), 3.80$ (s, 3H), 3.90-4.00 (m, 2H), $3.95(\mathrm{~s}, 2 \mathrm{H}), 4.43(\mathrm{~d}, J=11.2 \mathrm{~Hz}, 1 \mathrm{H}), 4.52$ (d, $J=11.2 \mathrm{~Hz}, 1 \mathrm{H}), 4.74(\mathrm{~d}, J=5.1$ $\mathrm{Hz}, 1 \mathrm{H}), 5.15$ (br d, $J=10.0 \mathrm{~Hz}, 1 \mathrm{H}), 5.56(\mathrm{br} \mathrm{d}, J=10.0 \mathrm{~Hz}, 1 \mathrm{H}), 5.60(\mathrm{~d}, J=12.2 \mathrm{~Hz}, 1 \mathrm{H}), 6.88(\mathrm{~m}, 2 \mathrm{H})$, $7.26(\mathrm{~m}, 2 \mathrm{H}) ;{ }^{13} \mathrm{C}-\mathrm{NMR}(68 \mathrm{MHz}) \delta-4.87,-4.67,-4.61,-4.15,19.23 \times 2,25.74 \times 3,25.89 \times 3,27.76,29.69$, $35.94,36.40,37.17,39.77,41.84,42.01,42.44,44.03,55.26,67.73,67.90,68.53,70.78,71.10,92.44,113.75$ $\times 2,129.01,129.18 \times 2,130.82,131.28,132.64,138.42,159.07$; IR (neat) 3400, 2930, 1730, 1615, 1515 $\mathrm{cm}^{-1}$; HRMS calcd for $\mathrm{C}_{39} \mathrm{H}_{66} \mathrm{O}_{6} \mathrm{Si}_{2}\left(\mathrm{M}^{+}\right) \mathrm{m} / \mathrm{z} 686.4398$, found 686.4428 .

\section{(2R,4R,6E,8Z,10S,11R,13E)-1-(2,2-Dimethyl-1,3-dioxin-4-one-6-yl)-15-methoxycarbonyloxy-10-[(4- methoxyphenyl)methoxy]-11-methyl-6,8,13-pentadecatrien-2,4-diol}
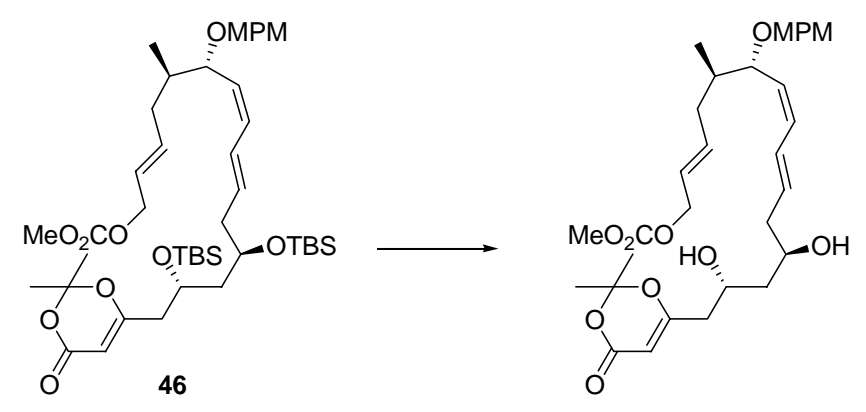

To a cooled $\left(0{ }^{\circ} \mathrm{C}\right)$, stirred solution of $46(522 \mathrm{mg}, 0.639 \mathrm{mmol})$ in pyridine $(10 \mathrm{~mL})$ was added HF-pyridine complex $(1 \mathrm{~mL})$. The mixture was stirred for $45 \mathrm{~h}$, and quenched with saturated aqueous $\mathrm{NaHCO}_{3}$. This was diluted with saturated aqueous $\mathrm{NaHCO}_{3}(50 \mathrm{~mL})$, and extracted with $\mathrm{CH}_{2} \mathrm{Cl}_{2}$. The combined organic layers were dried and concentrated in vacuo. The residue was purified by column chromatography on silica gel (EtOAc/hexane, 2:1 to EtOAc) to provide $384 \mathrm{mg}$ (quant.) of the diol as a colorless oil; TLC, $\mathrm{R}_{f} 0.25$ (EtOAc/hexane, 2:1); $[\alpha]^{25}{ }_{\mathrm{D}}-8.8\left(c 1.76, \mathrm{CHCl}_{3}\right) ;{ }^{1} \mathrm{H}-\mathrm{NMR}(300 \mathrm{MHz}) \delta 0.94(\mathrm{~d}, J=6.6 \mathrm{~Hz}, 3 \mathrm{H}), 1.53-1.89$ $(\mathrm{m}, 4 \mathrm{H}), 1.70 \times 2(2 \mathrm{~s}, 3 \mathrm{H} \times 2), 2.22-2.45(\mathrm{~m}, 5 \mathrm{H}), 2.80(\mathrm{~m}, 1 \mathrm{H}), 3.77(\mathrm{~s}, 3 \mathrm{H}), 3.77(\mathrm{~m}, 1 \mathrm{H}), 3.80(\mathrm{~s}, 3 \mathrm{H}), 3.94$ $(\mathrm{m}, 1 \mathrm{H}), 4.01(\mathrm{dd}, J=6.8,9.4 \mathrm{~Hz}, 1 \mathrm{H}), 4.18(\mathrm{~m}, 1 \mathrm{H}), 4.22,(\mathrm{~d}, J=11.4 \mathrm{~Hz}, 1 \mathrm{H}), 4.50(\mathrm{~d}, J=11.4 \mathrm{~Hz}, 1 \mathrm{H})$, $4.54(\mathrm{~d}, J=6.3 \mathrm{~Hz}, 2 \mathrm{H}), 5.33(\mathrm{t}, J=9.4 \mathrm{~Hz}, 1 \mathrm{H}), 5.34(\mathrm{~s}, 1 \mathrm{H}), 5.52(\mathrm{dt}, J=15.4,6.3 \mathrm{~Hz}, 1 \mathrm{H}), 5.64-5.78$ (m, 2H), 6.18-6.33 (m, 2H), $6.86(\mathrm{~m}, 2 \mathrm{H}), 7.22(\mathrm{~m}, 2 \mathrm{H}) ;{ }^{13} \mathrm{C}-\mathrm{NMR}(68 \mathrm{MHz}) \delta 15.06,24.71,25.17,35.36,38.04$, $41.44,41.90,42.04,54.65,55.17,68.45,69.17,69.54,71.79,76.77,95.06,106.55,113.54 \times 2,124.72$, $128.92,129.27 \times 2,129.93,130.65,130.99,131.74,135.46,155.56,158.93,161.17,168.86$; IR (neat) 3440 , 
2960, 1750, 1730, 1640, 1615, $1515 \mathrm{~cm}^{-1}$; HRMS (FAB) calcd for $\left(\mathrm{M}^{+}+\mathrm{H}\right) \mathrm{m} / \mathrm{z} 589.3013$, found 389.3005 .

(2E,5R,6S,7Z,9E,12R,14R)-15-(2,2-Dimethyl-1,3-dioxin-4-one-6-yl)-1-methoxycarbonyloxy-12,14-di(methoxymethoxy)-6-[(4-methoxyphenyl)methoxy]-5-methyl-2,7,9-pentadecatriene
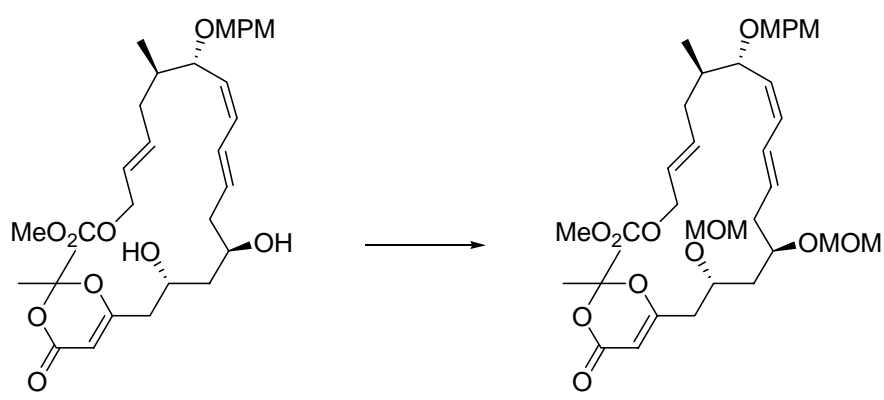

To a cooled $\left(0{ }^{\circ} \mathrm{C}\right)$, stirred solution of the diol $(384 \mathrm{mg}, 0.653 \mathrm{mmol})$ in $\mathrm{CH}_{2} \mathrm{Cl}_{2}(10 \mathrm{~mL})$ were added $i \operatorname{Pr}_{2} \mathrm{NEt}$ $(2.3 \mathrm{~mL}, 13 \mathrm{mmol})$ and $\mathrm{MOMCl}(0.50 \mathrm{~mL}, 6.5 \mathrm{mmol})$. The mixture was stirred for $23 \mathrm{~h}$ and $i \mathrm{Pr}_{2} \mathrm{NEt}(1.2 \mathrm{~mL}$, $6.9 \mathrm{mmol})$ and $\mathrm{MOMCl}(0.25 \mathrm{~mL}, 3.3 \mathrm{mmol})$ were added. This was stirred for $14.5 \mathrm{~h}$, and $i \mathrm{Pr}_{2} \mathrm{NEt}(0.4 \mathrm{~mL}$, $2.3 \mathrm{mmol})$ and $\mathrm{MOMCl}(0.10 \mathrm{~mL}, 1.3 \mathrm{mmol})$ were added. This was refluxed for $3.5 \mathrm{~h}$ and quenched with saturated aqueous $\mathrm{NaHCO}_{3}$. This was diluted with saturated aqueous $\mathrm{NH}_{4} \mathrm{Cl}(200 \mathrm{~mL})$, and extracted with $\mathrm{CH}_{2} \mathrm{Cl}_{2}$. The combined organic layers were dried and concentrated in vacuo. The residue was purified by column chromatography on silica gel (EtOAc/hexane, 2:3) to provide $405 \mathrm{mg}$ (94\%) of the di-MOM ether as a colorless oil; TLC, $\mathrm{R}_{f} 0.55$ (EtOAc/hexane, 2:1); $[\alpha]^{24}{ }_{\mathrm{D}}-30.2$ (c 1.67, $\mathrm{CHCl}_{3}$ ); ${ }^{1} \mathrm{H}-\mathrm{NMR}(270 \mathrm{MHz}) \delta 0.93$ $(\mathrm{d}, J=6.9 \mathrm{~Hz}, 3 \mathrm{H}), 1.68(\mathrm{~s}, 6 \mathrm{H}), 1.62-1.97(\mathrm{~m}, 4 \mathrm{H}), 2.23-2.57(\mathrm{~m}, 5 \mathrm{H}), 3.35,3.38(2 \mathrm{~s}, 3 \mathrm{H} \times 2), 3.74(\mathrm{~m}, 1 \mathrm{H})$, $3.76(\mathrm{~s}, 3 \mathrm{H}), 3.80(\mathrm{~s}, 3 \mathrm{H}), 4.00(\mathrm{~m}, 2 \mathrm{H}), 4.21,(\mathrm{~d}, J=11.7 \mathrm{~Hz}, 1 \mathrm{H}), 4.49(\mathrm{~d}, J=11.7 \mathrm{~Hz}, 1 \mathrm{H}), 4.54(\mathrm{~d}, J=6.2$ $\mathrm{Hz}, 2 \mathrm{H}), 4.61(\mathrm{~d}, J=7.0 \mathrm{~Hz}, 1 \mathrm{H}), 4.63(\mathrm{~s}, 2 \mathrm{H}), 4.69(\mathrm{~d}, J=7.0 \mathrm{~Hz}, 1 \mathrm{H}), 5.30(\mathrm{t}, J=9.5 \mathrm{~Hz}, 1 \mathrm{H}), 5.33(\mathrm{~s}, 1 \mathrm{H})$, $5.52(\mathrm{dt}, J=15.4,6.2 \mathrm{~Hz} 1 \mathrm{H}), 5.66-5.78(\mathrm{~m}, 2 \mathrm{H}), 6.18-6.33(\mathrm{~m}, 2 \mathrm{H}), 6.87(\mathrm{~m}, 2 \mathrm{H}), 7.22(\mathrm{~m}, 2 \mathrm{H})$; ${ }^{13} \mathrm{C}-\mathrm{NMR}$ $(68 \mathrm{MHz}) \delta 15.00,24.91,24.99,35.33,37.78,38.04,38.90,39.28,54.51,55.06,55.63 \times 2,68.36,69.43$, $71.73,73.57,76.89,95.11,95.17,95.55,106.29,113.49 \times 2,124.63,128.20,129.21 \times 2,129.35,130.65$, 131.45, 132.00, 135.46, 155.47, 158.90, 160.77, 168.66; IR (neat) 2960, 1750, 1730, 1640, 1615, $1515 \mathrm{~cm}^{-1}$; HRMS (FAB) calcd for $\left(\mathrm{M}^{+}+\mathrm{H}\right) \mathrm{m} / z$ 677.3537, found 677.3539.

Methyl (5R,7R,9E,11Z,13S,14R,16E)-18-(Methoxycarbonyl)oxy-5,7-di(methoxymethoxy)-13-[(4methoxyphenyl)methoxy]-14-methyl-3-oxo-9,11,16-octadecatriene-1-carboxylate (47b) 

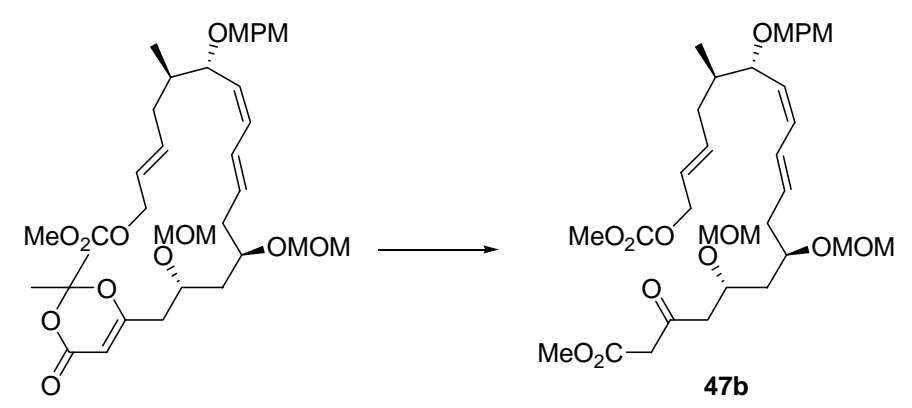

The dioxinone (405 mg $0.598 \mathrm{mmol})$ was dissolved in degassed toluene- $\mathrm{MeOH}(8: 1,8 \mathrm{~mL})$. The solution was transferred into a $20 \mathrm{~mL}$ sealed tube equipped with a screwed stopper, and the tube was filled with argon. The tube was heated to $110{ }^{\circ} \mathrm{C}$ for $5 \mathrm{~h}$. After being cooled to ambient temperature, the solution was concentrated in vacuo. The residue was purified by column chromatography on silica gel (EtOAc/hexane, 1:2) to provide $372 \mathrm{mg}(96 \%)$ of $\mathbf{4 7 b}$ as a colorless oil; TLC, $\mathrm{R}_{f} 0.55$ (EtOAc/hexane, 2:1); $[\alpha]^{23}{ }_{\mathrm{D}}-29.4(c$ 2.76, $\left.\mathrm{CHCl}_{3}\right) ;{ }^{1} \mathrm{H}-\mathrm{NMR}(270 \mathrm{MHz}) \delta 0.93(\mathrm{~d}, J=6.1 \mathrm{~Hz}, 3 \mathrm{H}), 1.60-1.94(\mathrm{~m}, 4 \mathrm{H}), 2.23-2.46(\mathrm{~m}, 3 \mathrm{H}$, $2 \mathrm{H} \times 1 / 10$, enol form), 2.75 (dd, $J=4.9,15.9 \mathrm{~Hz}, 1 \mathrm{H} \times 9 / 10$, keto form), 2.84 (dd, $J=6.7,15.9 \mathrm{~Hz}, 1 \mathrm{H} \times 9 / 10$, keto form), 3.33, 3.34 (2s, total $3 \mathrm{H}), 3.37,3.38$ (2s, total $3 \mathrm{H}), 3.49$ (s, $2 \mathrm{H} \times 9 / 10$, keto form), $3.73(\mathrm{~s}, 3 \mathrm{H}), 3.75$ (m, 1H), $3.77(\mathrm{~s}, 3 \mathrm{H}), 3.80(\mathrm{~s}, 3 \mathrm{H}), 4.01(\mathrm{dd}, J=5.8,9.0 \mathrm{~Hz}, 1 \mathrm{H}), 4.21,(\mathrm{~d}, J=11.6 \mathrm{~Hz}, 1 \mathrm{H}), 4.21(\mathrm{~m}, 1 \mathrm{H})$, $4.49(\mathrm{~d}, J=11.6 \mathrm{~Hz}, 1 \mathrm{H}), 4.54(\mathrm{~d}, J=6.1 \mathrm{~Hz}, 2 \mathrm{H}), 4.59-4.68(\mathrm{~m}, 4 \mathrm{H}), 5.07(\mathrm{~s}, 1 \mathrm{H} \times 1 / 10$, enol form), $5.28(\mathrm{t}$, $J=9.5 \mathrm{~Hz}, 1 \mathrm{H}), 5.53(\mathrm{dt}, J=15.3,6.1 \mathrm{~Hz}, 1 \mathrm{H}), 5.68-5.78(\mathrm{~m}, 2 \mathrm{H}), 6.19-6.33(\mathrm{~m}, 2 \mathrm{H}), 6.87(\mathrm{~m}, 2 \mathrm{H}), 7.23(\mathrm{~m}$, 2H), $12.04\left(\mathrm{~s}, 1 \mathrm{H} \times 1 / 10\right.$, enol form); ${ }^{13} \mathrm{C}-\mathrm{NMR}(68 \mathrm{MHz}$, keto + enol form) $\delta 15.09,35.42,37.89,38.10$, 39.28, 47.83, 49.90, 51.09 (enol), 52.24, 54.60, 55.17, 55.64, 55.72 ×2, 68.48, 69.51, 71.39, 71.82 (enol), 73.80, 90.91 (enol), 95.34, 95.52 (enol), 95.98, 113.54 × 2, 124.66, 128.17, 129.24, $129.30 \times 2,130.79$, 131.71, 131.83 (enol), 132.20, 135.63, 155.56, 158.96, 167.39, 175.25 (enol), 201.00; IR (neat) 2950, 1750, $1615,1515 \mathrm{~cm}^{-1}$; HRMS calcd for $\mathrm{C}_{34} \mathrm{H}_{50} \mathrm{O}_{12}\left(\mathrm{M}^{+}\right) \mathrm{m} / \mathrm{z}$ 650.3302, found 650.3297 .

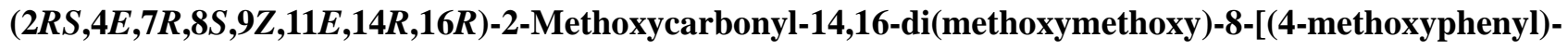
methoxy]-7-methyl-4,9,11-cycloheptadecatrien-1-one (48b, ca. 3:2 diastereomeric mixture)

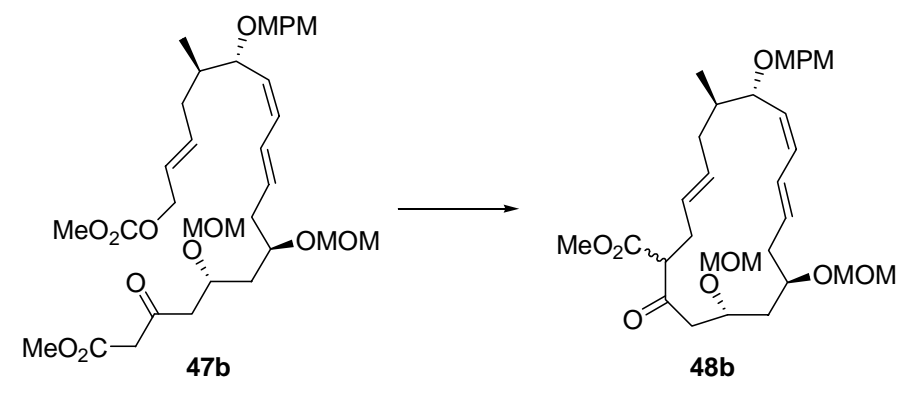

To a stirred solution of $\mathbf{4 7 b}(98.0 \mathrm{mg}, 0.151 \mathrm{mmol})$ in degassed THF $(50 \mathrm{~mL})$ were added $\mathrm{Pd}\left(\mathrm{PPh}_{3}\right)_{4}(32.2 \mathrm{mg}$, 
$0.0279 \mathrm{mmol})$ and dppe $(11.0 \mathrm{mg}, 0.0279 \mathrm{mmol})$ in THF $(6 \mathrm{~mL})$. The mixture was stirred for $3 \mathrm{~h}$, and then concentrated in vacuo. The residue was purified by column chromatography on silica gel (EtOAc/hexane, 1:2 to $1: 1)$ to provide $73.1 \mathrm{mg}(84 \%)$ of $\mathbf{4 8 b}$ as a colorless oil; TLC, $\mathrm{R}_{f} 0.61$ (EtOAc/hexane, 2:1); $[\alpha]^{21}{ }_{\mathrm{D}}+30.2(c$ 1.26, $\left.\mathrm{CHCl}_{3}\right) ;{ }^{1} \mathrm{H}-\mathrm{NMR}(300 \mathrm{MHz}) \delta 0.96(\mathrm{~d}, J=6.9 \mathrm{~Hz}, 3 \mathrm{H}), 1.57(\mathrm{~m}, 1 \mathrm{H}), 1.74-1.95(\mathrm{~m}, 3 \mathrm{H}), 2.17(\mathrm{~m}, 1 \mathrm{H})$, 2.35-2.92 (m, 6H), 3.33, 3.34, $3.39(3 \mathrm{~s}$, total $6 \mathrm{H}), 3.36(\mathrm{~m}, 1 \mathrm{H} \times 3 / 5), 3.52(\mathrm{~m}, 1 \mathrm{H} \times 2 / 5), 3.67,3.71,3.74(3 \mathrm{~s}$, total $3 \mathrm{H}), 3.81,3.82(2 \mathrm{~s}$, total $3 \mathrm{H}), 3.87(\mathrm{~m}, 1 \mathrm{H}), 4.04-4.22(\mathrm{~m}, 3 \mathrm{H}), 4.46-4.68(\mathrm{~m}, 5 \mathrm{H}), 5.25(\mathrm{~m}, 1 \mathrm{H})$, 5.35-5.45 (m, 2H), $5.75(\mathrm{~m}, 1 \mathrm{H}), 5.98-6.24(\mathrm{~m}, 1 \mathrm{H}+1 \mathrm{H} \times 3 / 5), 6.39(\mathrm{dd}, J=11.7,15.0 \mathrm{~Hz}, 1 \mathrm{H} \times 2 / 5), 6.88$ $(\mathrm{m}, 2 \mathrm{H}), 7.25(\mathrm{~m}, 2 \mathrm{H})$, [enol: $12.84(\mathrm{~s}, 1 \mathrm{H} \times 3 / 5)$ ]; ${ }^{13} \mathrm{C}-\mathrm{NMR}(68 \mathrm{MHz}$, signals for two diastereomeric keto tautomer + one enol tautomer) $\delta 14.78,14.86,15.33,27.57,30.75,30.79,35.65,36.25,36.36,36.45,36.81$, $37.85,37.91,38.53,38.89,39.26,39.31,40.86,47.98,48.60,51.62,52.31,52.35,55.07,55.14,55.18,55.24$, 55.43, 55.46, 55.49, 55.55, 55.61, 55.64, 55.87, 57.46, 57.98, 69.30, 69.64, 71.04, 71.35, 71.84, 72.95, 72.98, $73.41,73.55,74.22,74.34,94.89,94.97,95.14,96.09,96.34,113.57,113.60,124.93,126.63,127.36,127.47$, $128.42,128.45,129.23,129.35,129.64,129.78,130.71,130.89,130.94,130.98,131.03,131.20,131.34$, $131.61,131.90,132.05,132.19,132.63,158.92,158.95,169.55,169.66,173.60,202.52,202.91$; IR (neat) 2930, 1750, 1715, 1650, 1615, 1585, $1515 \mathrm{~cm}^{-1}$; HRMS calcd for $\mathrm{C}_{32} \mathrm{H}_{46} \mathrm{O}_{9}\left(\mathrm{M}^{+}\right) \mathrm{m} / z$ 574.3141, found 574.3147.

(2Z,4E,7R,8S,9Z,11E,14R,16R)-2-Methoxycarbonyl-14,16-di(methoxymethoxy)-8-[(4-methoxyphenyl)methoxy]-7-methyl-2,4,9,11-cycloheptadecatetraen-1-one (49)

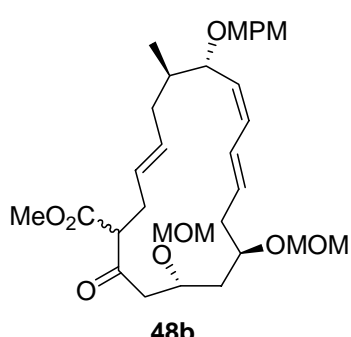

48b

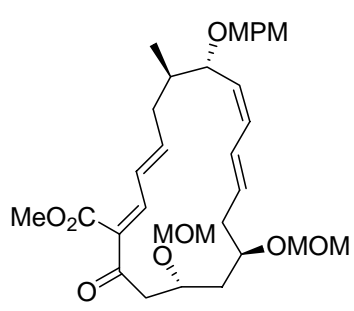

49

The following reaction was carried out under argon. To a cooled $\left(-78{ }^{\circ} \mathrm{C}\right)$, stirred solution of $\mathbf{4 8 b}(274 \mathrm{mg}$, $0.477 \mathrm{mmol})$ in THF $(6 \mathrm{~mL})$ was added NaHMDS (1.0 M in THF, $1.0 \mathrm{~mL}, 1.0 \mathrm{mmol})$. The mixture was stirred for $1 \mathrm{~h}$ at $-78{ }^{\circ} \mathrm{C}$ and a solution of $\mathrm{PhSeCl}(245 \mathrm{mg}, 1.21 \mathrm{mmol})$ in toluene $(2 \mathrm{~mL})$ was added. After being stirred at $-78{ }^{\circ} \mathrm{C}$ for $2 \mathrm{~h}$, the solution was quenched with saturated aqueous $\mathrm{NH}_{4} \mathrm{Cl}$. This was diluted with saturated aqueous $\mathrm{NH}_{4} \mathrm{Cl}(60 \mathrm{~mL})$ and extracted with $\mathrm{CH}_{2} \mathrm{Cl}_{2}$. The combined organic layers were dried and concentrated in vacuo. The residue was purified by column chromatography on silica gel (toluene/hexane, 1:3 to EtOAc /hexane, 1:4) to provide $331 \mathrm{mg}(95 \%)$ of the selenide as a colorless oil.

The following reaction was carried out under argon. To a cooled $\left(-78{ }^{\circ} \mathrm{C}\right)$, stirred solution of the selenide (331 mg, $0.453 \mathrm{mmol}$ ) in $\mathrm{CH}_{2} \mathrm{Cl}_{2}(8 \mathrm{~mL}$ ) was added a solution of mCPBA (164.0 mg, $0.950 \mathrm{mmol})$ in $\mathrm{CH}_{2} \mathrm{Cl}_{2}$ 
( $3 \mathrm{~mL}$ ). The mixture was stirred for $3 \mathrm{~h}$ at $-78{ }^{\circ} \mathrm{C}$ and quenched with $20 \%$ aqueous $\mathrm{Na}_{2} \mathrm{~S}_{2} \mathrm{O}_{3}$ and saturated aqueous $\mathrm{NaHCO}_{3}$. This was diluted with saturated aqueous $\mathrm{NaHCO}_{3}(50 \mathrm{~mL})$, and extracted with $\mathrm{CH}_{2} \mathrm{Cl}_{2}$. The combined organic layers were dried and concentrated in vacuo. The residue was purified by column chromatography on silica gel (EtOAc/toluene, 1:6) to provide $140.3 \mathrm{mg}(54 \%)$ of $\mathbf{4 9}(\mathrm{Z} / E>20: 1)$ as a colorless oil; TLC, $\mathrm{R}_{f} 0.43$ (EtOAc/hexane, 1:1); $\left.\alpha\right]^{22}{ }_{\mathrm{D}}-83.5\left(c 1.76, \mathrm{CHCl}_{3}\right) ;{ }^{1} \mathrm{H}-\mathrm{NMR}(270 \mathrm{MHz}) \delta 1.18(\mathrm{~d}$, $J=7.0 \mathrm{~Hz}, 3 \mathrm{H}), 1.72(\mathrm{~m}, 2 \mathrm{H}), 1.88(\mathrm{~m}, 1 \mathrm{H}), 2.12-2.29(\mathrm{~m}, 2 \mathrm{H}), 2.37-2.52(\mathrm{~m}, 2 \mathrm{H}), 2.79(\mathrm{dd}, J=8.4,13.2$ $\mathrm{Hz}, 1 \mathrm{H}), 3.20(\mathrm{dd}, J=4.4,13.2 \mathrm{~Hz}, 1 \mathrm{H}), 3.37,3.38(2 \mathrm{~s}, 3 \mathrm{H} \times 2), 3.63(\mathrm{~m}, 1 \mathrm{H}), 3.81(\mathrm{~s}, 3 \mathrm{H}), 3.82(\mathrm{~m}, 1 \mathrm{H})$, $3.82(\mathrm{~s}, 3 \mathrm{H}), 3.98(\mathrm{~m}, 1 \mathrm{H}), 4.17(\mathrm{~d}, J=11.4 \mathrm{~Hz}, 1 \mathrm{H}), 4.47$ (d, $J=11.4 \mathrm{~Hz}, 1 \mathrm{H}), 4.60-4.72(\mathrm{~m}, 4 \mathrm{H}), 5.25$ (t, $J$ $=10.3 \mathrm{~Hz}, 1 \mathrm{H}), 5.69(\mathrm{ddd}, J=4.8,9.9,14.7 \mathrm{~Hz}, 1 \mathrm{H}), 6.07(\mathrm{dd}, J=11.0,14.7 \mathrm{~Hz}, 1 \mathrm{H}), 6.17-6.27(\mathrm{~m}, 2 \mathrm{H})$, $6.54(\mathrm{dd}, J=11.5,14.8 \mathrm{~Hz}, 1 \mathrm{H}), 6.87(\mathrm{~m}, 2 \mathrm{H}), 7.07(\mathrm{~d}, J=11.5 \mathrm{~Hz}, 1 \mathrm{H}), 7.22(\mathrm{~m}, 2 \mathrm{H}) ;{ }^{13} \mathrm{C}-\mathrm{NMR}(68 \mathrm{MHz})$ $\delta 17.00,37.15,37.43,39.97,40.08,45.27,51.95,55.20,55.60,55.72,69.14,72.08,74.26,75.85,95.29$, $95.37,113.60 \times 2,127.97,128.03,129.30 \times 2,130.71 \times 2,131.40,132.38,132.78,146.29,147.12,159.04$, 165.78, 197.95; IR (neat) 2950, 1730, 1680, 1630, 1585, $1515 \mathrm{~cm}^{-1}$; HRMS calcd for $\mathrm{C}_{32} \mathrm{H}_{44} \mathrm{O}_{9}\left(\mathrm{M}^{+}\right) \mathrm{m} / \mathrm{z}$ 572.2985, found 572.2980 .

\section{Intramolecular Diels-Alder reaction of 49}

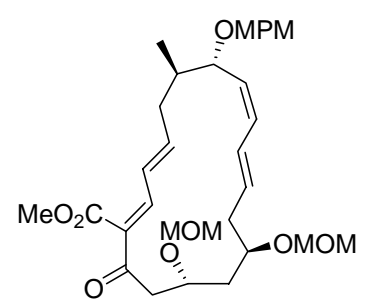

49

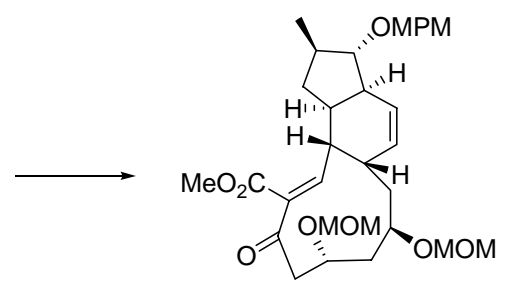

50

The compound 49 (31.8 mg, $0.0555 \mathrm{mmol})$ was dissolved in degassed toluene (8 mL), and a crystal of BHT was added. The solution was transferred into a $20 \mathrm{~mL}$ sealed tube equipped with a screwed stopper, and the tube was filled with argon. The tube was heated to $130{ }^{\circ} \mathrm{C}$ for $80 \mathrm{~h}$. After being cooled to ambient temperature, the solution was concentrated in vacuo. The residue was purified by column chromatography on silica gel (EtOAc/toluene, 1:7) to provide $9.1 \mathrm{mg}(29 \%)$ of $\mathbf{5 0}$ as a colorless oil; TLC, $\mathrm{R}_{f} 0.32$ (EtOAc/toluene, 1:1); $[\alpha]^{22}{ }_{\mathrm{D}}-0.5\left(\mathrm{c} 0.840, \mathrm{CHCl}_{3}\right) ;{ }^{1} \mathrm{H}-\mathrm{NMR}(270 \mathrm{MHz}) \delta 1.06(\mathrm{~d}, J=6.6 \mathrm{~Hz}, 3 \mathrm{H}), 1.68(\mathrm{~m}, 2 \mathrm{H}) 1.82-2.18$ $(\mathrm{m}, 5 \mathrm{H}), 2.26(\mathrm{~m}, 1 \mathrm{H}), 2.52(\mathrm{~m}, 1 \mathrm{H}), 2.65(\mathrm{~m}, 1 \mathrm{H}), 2.85(\mathrm{dd}, J=6.2,13.6 \mathrm{~Hz}, 1 \mathrm{H}), 3.03(\mathrm{td}, J=10.3,4.7 \mathrm{~Hz}$, 1H), $3.16(\mathrm{~m}, 1 \mathrm{H}), 3.22(\mathrm{t}, J=7.7 \mathrm{~Hz}, 1 \mathrm{H}), 3.37(\mathrm{~s}, 6 \mathrm{H}), 3.66(\mathrm{~m}, 1 \mathrm{H}), 3.81(\mathrm{~s}, 3 \mathrm{H}), 3.82(\mathrm{~s}, 3 \mathrm{H}), 3.93$ (m, $1 \mathrm{H}), 4.50-4.70(\mathrm{~m}, 6 \mathrm{H}), 5.74(\mathrm{~m}, 1 \mathrm{H}), 5.87(\mathrm{~m}, 1 \mathrm{H}), 6.44(\mathrm{br} \mathrm{d}, J=10.3 \mathrm{~Hz}, 1 \mathrm{H}), 6.88(\mathrm{~m}, 2 \mathrm{H}), 7.28(\mathrm{~m}$, $2 \mathrm{H}) ;{ }^{13} \mathrm{C}-\mathrm{NMR}(75 \mathrm{MHz}) \delta 18.79,29.68,35.80,36.39,39.68,43.46,44.80,52.33,55.26,55.57,71.76,72.58$, $73.04,91.53,94.64,95.02,113.79 \times 2,129.22 \times 3,130.81 \times 2,137.56,153.40,159.15,164.96,198.63(4$ carbons were not detected, but the structure was confirmed by a ${ }^{1} \mathrm{H}-{ }^{1} \mathrm{H}$ COSY analysis.); IR (neat) 2950, 
1730, 1700, 1670, 1615, $1515 \mathrm{~cm}^{-1}$; HRMS calcd for $\mathrm{C}_{32} \mathrm{H}_{44} \mathrm{O}_{9}\left(\mathrm{M}^{+}\right) \mathrm{m} / z$ 572.2985, found 572.2988.

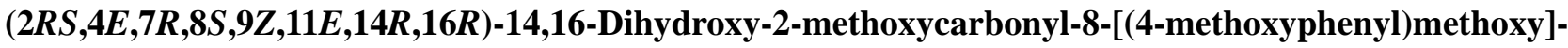
7-methyl-4,9,11-cycloheptadecatrien-1-one

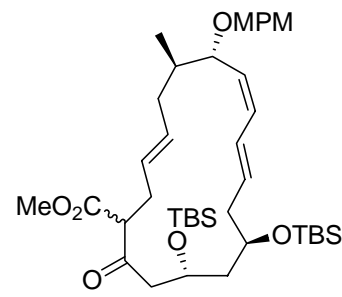

$48 a$

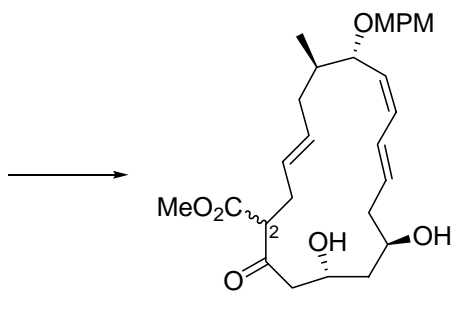

To a cooled $\left(0{ }^{\circ} \mathrm{C}\right)$, stirred solution of $\mathbf{4 8 a}(73.6 \mathrm{mg}, 0.103 \mathrm{mmol})$ in pyridine $(5 \mathrm{~mL})$ was added HF-pyridine complex $(0.5 \mathrm{~mL})$. The mixture was stirred for $30 \mathrm{~h}$, and quenched with saturated aqueous $\mathrm{NaHCO}_{3}$. This was diluted with saturated aqueous $\mathrm{NaHCO}_{3}(60 \mathrm{~mL})$, and extracted with $\mathrm{CH}_{2} \mathrm{Cl}_{2}$. The combined organic layers were dried and concentrated in vacuo to give the crude diol, which was used in the next step without purification. In a small-scale experiment, a pure sample was obtained by column chromatography on silica gel (EtOAc/hexane, 2:3 to 1:1) as an amorphous solid; TLC, $\mathrm{R}_{f} 0.37$ (acetone/toluene, 1:2), HRMS calcd for $\mathrm{C}_{28} \mathrm{H}_{38} \mathrm{O}_{7}\left(\mathrm{M}^{+}\right) \mathrm{m} / z$ 486.2618, found 486.2618.

This compound showed a complicated ${ }^{1} \mathrm{H}-\mathrm{NMR}$ spectrum, making its analysis extremely difficult. We attribute this complication to the presence of tautomers such as a hemiketal form and/or rotamers, in addition to diastereomers concening $\mathrm{C}(2)$.

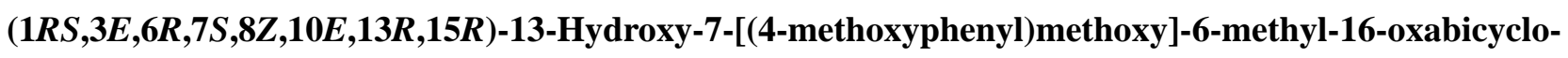

\section{[13.2.2]nonadeca-3,8,10-triene-17,18-dione}
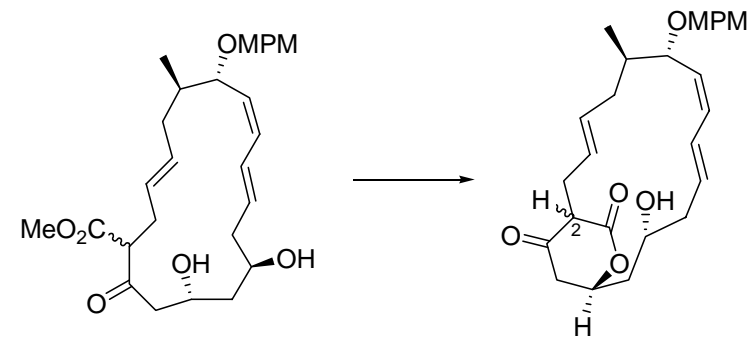

To a cooled $\left(0{ }^{\circ} \mathrm{C}\right)$, stirred solution of the crude diol obtained above in $\mathrm{MeOH}(5 \mathrm{~mL})$ was added $i \operatorname{Pr}_{2} \mathrm{NEt}(0.5$ $\mathrm{mL}$ ). The mixture was stirred for $24 \mathrm{~h}$, and then azeotroped with toluene to give the crude lactone, which was 
used in the next step without purification. In a small-scale experiment, a pure sample was obtained by column chromatography on silica gel (acetone/toluene, $1: 3$ to $1: 1$ ) as an amorphous solid; TLC, $\mathrm{R}_{f} 0.27$ (acetone/toluene, 1:1), HRMS calcd for $\mathrm{C}_{27} \mathrm{H}_{34} \mathrm{O}_{6}\left(\mathrm{M}^{+}\right) \mathrm{m} / \mathrm{z}$ 454.2355, found 454.2353.

This compound showed a complicated ${ }^{1} \mathrm{H}-\mathrm{NMR}$ spectrum, making its analysis extremely difficult. We attribute this complication to the presence of tautomers such as a hemiketal form and/or rotamers, in addition to diastereomers concening $\mathrm{C}(2)$.

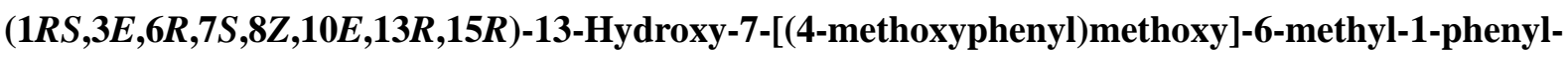 selenyl-16-oxabicyclo[13.2.2]nonadeca-3,8,10-triene-17,18-dione}

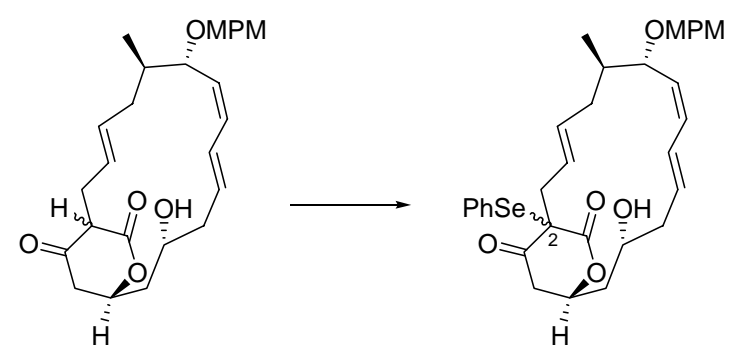

The following reaction was carried out under argon. To a stirred solution of the crude lactone obtained above in $\mathrm{CH}_{2} \mathrm{Cl}_{2}(2 \mathrm{~mL})$ was added $\mathrm{Et}_{3} \mathrm{~N}(0.057 \mathrm{~mL}, 0.41 \mathrm{mmol})$. The mixture was stirred for $10 \mathrm{~min}$, and a solution of $\mathrm{PhSeCl}(41.2 \mathrm{mg}, 0.215 \mathrm{mmol})$ in $\mathrm{CH}_{2} \mathrm{Cl}_{2}(0.2 \mathrm{~mL})$ was added at $-78{ }^{\circ} \mathrm{C}$. The mixture was stirred for 30 min at $-78{ }^{\circ} \mathrm{C}$, and then a solution of $\mathrm{PhSeCl}(9.9 \mathrm{mg}, 0.052 \mathrm{mmol})$ in $\mathrm{CH}_{2} \mathrm{Cl}_{2}(0.2 \mathrm{~mL})$ was added. The mixture was stirred for $30 \mathrm{~min}$, and then diluted with toluene $(4 \mathrm{~mL})$ at $-78{ }^{\circ} \mathrm{C}$. The mixture cooled to $-78{ }^{\circ} \mathrm{C}$ was directly transferred into a short column packed with silica gel. The column was eluted with the following cooling (dry ice-acetone bath) solvents (toluene, $\mathrm{CH}_{2} \mathrm{Cl}_{2}$, then EtOAc) successively, to prevent the decomposition of the selenide. The elute was concentrated in vacuo to provide $55.7 \mathrm{mg}$ (89\%, 3 steps from 48a) of the phenylselenide as an amorphous solid; TLC, $\mathrm{R}_{f} 0.57$ (acetone/toluene, 1:2), HRMS calcd for $\mathrm{C}_{33} \mathrm{H}_{38} \mathrm{O}_{6} \mathrm{Se}\left(\mathrm{M}^{+}\right) \mathrm{m} / \mathrm{z}$ 610.1833, found 610.1842.

This compound showed a complicated ${ }^{1} \mathrm{H}-\mathrm{NMR}$ spectrum, making its analysis extremely difficult. We attribute this complication to the presence of tautomers such as a hemiketal form and/or rotamers, in addition to diastereomers concening $\mathrm{C}(2)$.

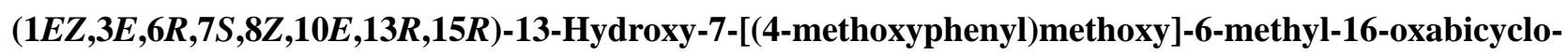
[13.2.2]nonadeca-1,3,8,10-tetraene-17,18-dione (17) 

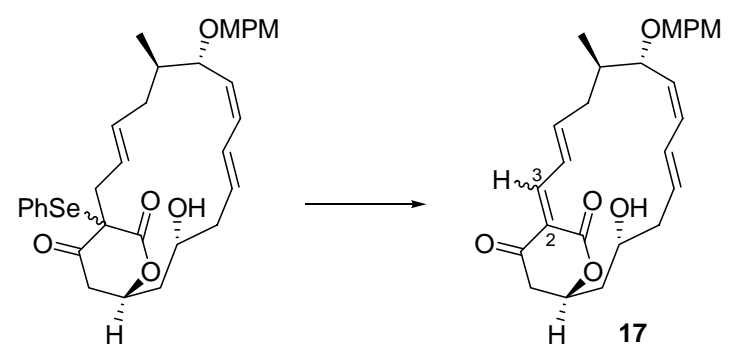

The following reaction was carried out under argon. To a cooled $\left(-50{ }^{\circ} \mathrm{C}\right)$ stirred solution of the selenide (159 $\mathrm{mg}, 0.260 \mathrm{~mol})$ in $\mathrm{CH}_{2} \mathrm{Cl}_{2}(5 \mathrm{~mL})$ was added mCPBA $(125 \mathrm{mg}, 0.724 \mathrm{mmol})$. The mixture was stirred for 3.5 $\mathrm{h}$ at $-50{ }^{\circ} \mathrm{C}$, and quenched with $\mathrm{Me}_{2} \mathrm{~S}$. The mixture was stirred for $0.5 \mathrm{~h}$ and then diluted with saturated aqueous $\mathrm{NaHCO}_{3}(20 \mathrm{~mL})$. This was extracted with $\mathrm{CH}_{2} \mathrm{Cl}_{2}$, and the combined organic layers were dried and concentrated in vacuo. The residue was filtered through silica gel to provide $118 \mathrm{mg}$ of $\mathbf{1 7}$ as a pale yellow oil, which was used in the next step immediately; TLC, $\mathrm{R}_{f} 0.31$ (acetone/toluene, 1:2), HRMS calcd for $\mathrm{C}_{27} \mathrm{H}_{32} \mathrm{O}_{6}$ $\left(\mathrm{M}^{+}\right) m / z$ 452.2199, found 452.2195.

This compound showed a complicated ${ }^{1} \mathrm{H}-\mathrm{NMR}$ spectrum, making its analysis extremely difficult. We attribute this complication to the presence of tautomers such as a hemiketal form and/or rotamers, in addition to geometrical isomers regarding $\mathrm{C}(2)-\mathrm{C}(3)$ double bond.

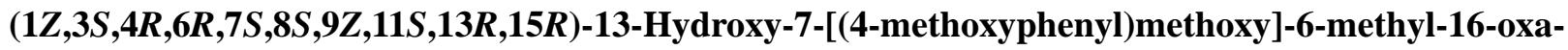
tetracyclo[13.2.2.0 $\left.{ }^{3,11} \cdot 0^{4,8}\right]$ nonadeca-1,9-diene-17,18-dione (13)

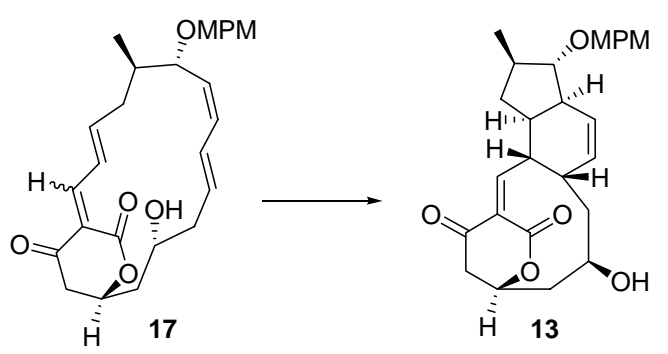

The compound 17 (118 mg, $0.260 \mathrm{mmol})$ was dissolved in degassed toluene (16 mL), and a crystal of BHT was added. The solution was divided into two $20 \mathrm{~mL}$ sealed tubes equipped with a screwed stopper, and the tubes were filled with argon. The tubes were heated to $130{ }^{\circ} \mathrm{C}$ for $26 \mathrm{~h}$. After being cooled to ambient temperature, the combined solution was concentrated in vacuo. The residue was purified by column chromatography on silica gel (EtOAc/toluene, 1:2) to provide $62.1 \mathrm{mg}$ (53\%, 2 steps from the phenylselenide) of $\mathbf{1 3}$ as a colorless oil; TLC, $\mathrm{R}_{f} 0.31$ (acetone/toluene, 1:2); $[\alpha]^{23}{ }_{\mathrm{D}}+37.5\left(c 0.625, \mathrm{CHCl}_{3}\right.$ ); ${ }^{1} \mathrm{H}-\mathrm{NMR}(270 \mathrm{MHz}) \delta 1.08(\mathrm{~d}, J=6.6 \mathrm{~Hz}, 3 \mathrm{H}), 1.48(\mathrm{q}, J=12.1 \mathrm{~Hz}, 1 \mathrm{H}), 1.64-1.87(\mathrm{~m}, 3 \mathrm{H}), 1.90-2.06(\mathrm{~m}$, $2 \mathrm{H}), 2.42-2.57(\mathrm{~m}, 2 \mathrm{H}), 2.66(\mathrm{dd}, J=0.7,18.7 \mathrm{~Hz}, 1 \mathrm{H}), 2.70-2.83(\mathrm{~m}, 2 \mathrm{H}), 3.12(\mathrm{ddd}, J=0.7,7.3,18.7 \mathrm{~Hz}$, 
$1 \mathrm{H}), 3.26(\mathrm{dd}, J=2.7,6.8 \mathrm{~Hz}, 1 \mathrm{H}), 3.32(\mathrm{~m}, 1 \mathrm{H}), 3.65(\mathrm{~m}, 1 \mathrm{H}), 3.81(\mathrm{~s}, 3 \mathrm{H}), 4.44,4.57(2 \mathrm{~d}, J=11.2 \mathrm{~Hz}$, $1 \mathrm{H} \times 2), 4.89(\mathrm{~m}, 1 \mathrm{H}), 5.68(\mathrm{~d}, J=10.4 \mathrm{~Hz}, 1 \mathrm{H}), 5.73(\mathrm{~d}, J=10.4 \mathrm{~Hz}, 1 \mathrm{H}), 6.86-6.91(\mathrm{~m}, 3 \mathrm{H}), 7.29(\mathrm{~m}, 2 \mathrm{H})$; ${ }^{13} \mathrm{C}-\mathrm{NMR}(68 \mathrm{MHz}) \delta 18.69,35.22,35.53,37.61,39.62,39.88,41.26,41.32,41.75,45.61,55.29,66.86$, $71.53,72.71,92.38,113.83 \times 2,124.83,129.27 \times 2,130.50,131.02,135.95,157.03,159.16,165.72,194.23$; IR (neat) 3450, 2950, 1735, 1705, 1620, $1515 \mathrm{~cm}^{-1}$; HRMS calcd for $\mathrm{C}_{27} \mathrm{H}_{32} \mathrm{O}_{6}\left(\mathrm{M}^{+}\right) \mathrm{m} / z$ 452.2199, found 452.2195 . 


\subsection{Completion of the Total Synthesis}

$(1 S, 2 S, 3 S, 4 Z, 6 S, 7 S, 8 R)-3-\{(2 R)-2-(t-B u t y l d i m e t h y l s i l y l o x y)-3-[(6 R)-2,4-d i o x o p y r a n-6-y l] p r o p y l\}-2-$ formyl-7-[(4-methoxyphenyl)methoxy]-8-methylbicyclo[4.3.0]non-4-ene (53)
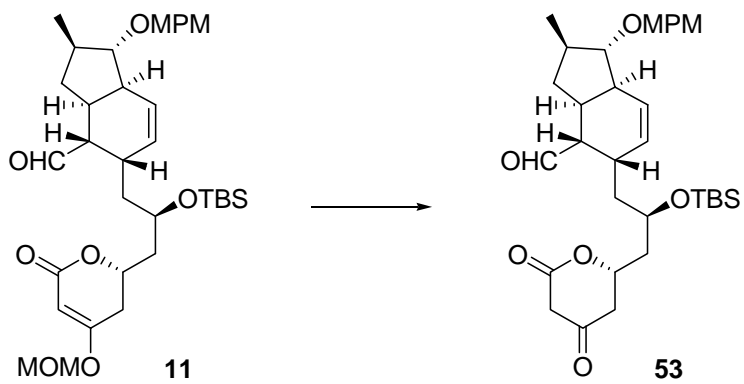

To a cooled $\left(0{ }^{\circ} \mathrm{C}\right)$, stirred solution of $\mathbf{1 1}(32.3 \mathrm{mg}, 0.0514 \mathrm{mmol})$ in $\mathrm{Et}_{2} \mathrm{O}(1 \mathrm{~mL})$ were added $\mathrm{EtSH}(0.019$ $\mathrm{mL}, 0.257 \mathrm{mmol})$ and $\mathrm{MgBr}_{2} \cdot \mathrm{OEt}_{2}(13.3 \mathrm{mg}, 0.0514 \mathrm{mmol})$. The mixture was stirred for $8 \mathrm{~h}$ and quenched with saturated aqueous $\mathrm{NaHCO}_{3}$. This was diluted with saturated aqueous $\mathrm{NaHCO}_{3}(10 \mathrm{~mL})$, and extracted with $\mathrm{CH}_{2} \mathrm{Cl}_{2}$. The combined organic layers were dried and concentrated in vacuo. The residue was purified by column chromatography on silica gel (EtOAc/hexane, 1:1) to provide $19.1 \mathrm{mg}(64 \%)$ of $\mathbf{5 3}$ as a colorless oil; TLC, $\mathrm{R}_{f} 0.23$ (EtOAc/hexane, 1:1); $[\alpha]^{24}{ }_{\mathrm{D}}+28.3\left(c 0.40, \mathrm{CHCl}_{3}\right) ;{ }^{1} \mathrm{H}$ NMR $(300 \mathrm{MHz}) \delta 0.07,0.08(2 \mathrm{~s}, 3 \mathrm{H}$ $\times 2), 0.88(\mathrm{~s}, 9 \mathrm{H}), 1.06(\mathrm{~d}, J=6.5 \mathrm{~Hz}, 3 \mathrm{H}), 1.11(\mathrm{~m}, 1 \mathrm{H}), 1.50(\mathrm{~m}, 1 \mathrm{H}), 1.61-1.84(\mathrm{~m}, 2 \mathrm{H}), 1.97-2.12(\mathrm{~m}$, $3 \mathrm{H}), 2.39-2.52(\mathrm{~m}, 2 \mathrm{H}), 2.63-2.77(\mathrm{~m}, 4 \mathrm{H}), 3.18(\mathrm{dd}, J=4.4,6.9 \mathrm{~Hz}, 1 \mathrm{H}), 3.44,3.62(2 \mathrm{~d}, J=19.0 \mathrm{~Hz}, 1 \mathrm{H}$ $\times 2), 3.81(\mathrm{~s}, 3 \mathrm{H}), 4.07(\mathrm{~m}, 1 \mathrm{H}), 4.48,4.56(2 \mathrm{~d}, J=11.0 \mathrm{~Hz}, 1 \mathrm{H} \times 2), 4.76(\mathrm{~m}, 1 \mathrm{H}), 5.71(\mathrm{br} \mathrm{d}, J=10.5 \mathrm{~Hz}$, $1 \mathrm{H}), 5.83(\mathrm{br} \mathrm{d}, J=10.5 \mathrm{~Hz}, 1 \mathrm{H}), 6.89(\mathrm{~m}, 2 \mathrm{H}), 7.27(\mathrm{~m}, 2 \mathrm{H}), 9.70(\mathrm{~d}, J=2.4 \mathrm{~Hz}, 1 \mathrm{H}) ;{ }^{13} \mathrm{C} \mathrm{NMR}(75 \mathrm{MHz})$ $\delta-4.64,-4.15,17.94,18.37,25.77 \times 3,28.56,34.09,36.80,39.10,39.56,42.62,43.54,44.09,47.17,54.65$, $55.26,65.88,72.11,72.25,92.15,113.80 \times 2,127.80,129.27 \times 2,130.59,130.97,159.19,166.85,199.53$, 204.71; IR (neat) 2950, 1715, 1615, $1515 \mathrm{~cm}^{-1}$; HRMS calcd for $\mathrm{C}_{32} \mathrm{H}_{48} \mathrm{O}_{5} \mathrm{Si}\left(\mathrm{M}^{+}-\mathrm{CO}_{2}\right) \mathrm{m} / z$ 540.3271, found 540.3252 .

$(1 S, 2 Z, 6 R, 8 R, 10 S, 11 Z, 13 S, 14 S, 15 R, 17 R)$-14-Hydroxy-3-methoxycarbonyl-6,8-di(methoxymethoxy)-15methyltricyclo[8.7.0.0 $\left.{ }^{13,17}\right]$ heptadeca-2,11-dien-4-one

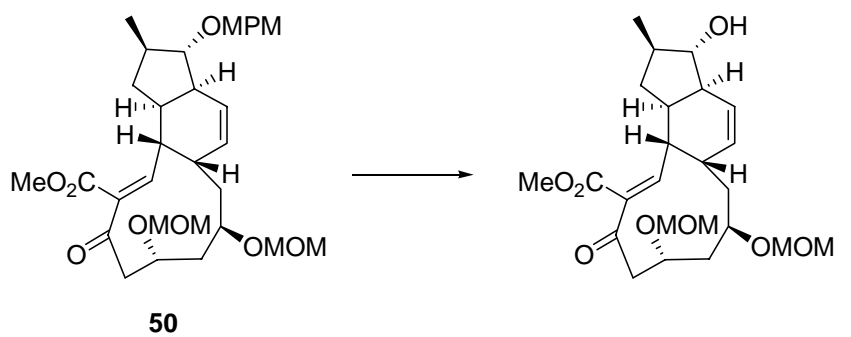


To a stirred solution of $\mathbf{5 0}(12.6 \mathrm{mg}, 0.022 \mathrm{mmol})$ in $\mathrm{CH}_{2} \mathrm{Cl}_{2}(1 \mathrm{~mL})$ was added $\mathrm{H}_{2} \mathrm{O}(0.05 \mathrm{~mL})$. This was stirred for $30 \mathrm{~min}$ and then DDQ $(8.1 \mathrm{mg}, 0.036 \mathrm{mmol})$ was added at $0{ }^{\circ} \mathrm{C}$. The mixture was stirred for $3 \mathrm{~h}$, and quenched with saturated aqueous $\mathrm{NaHCO}_{3}$. This was diluted with saturated aqueous $\mathrm{NaHCO}_{3}(10 \mathrm{~mL})$, and extracted with $\mathrm{CH}_{2} \mathrm{Cl}_{2}$. The combined organic layers were dried and concentrated in vacuo. The residue was purified by column chromatography on silica gel (acetone/toluene, 1:7) to provide $9.0 \mathrm{mg}(90 \%)$ of the secondary alcohol as a colorless oil; TLC, $\mathrm{R}_{f} 0.46$ (acetone/toluene, 1:2); $[\alpha]^{22}+2.74$ (c $0.660, \mathrm{CHCl}_{3}$ ); ${ }^{1} \mathrm{H}-\mathrm{NMR}(270 \mathrm{MHz}) \delta 0.86(\mathrm{~m}, 1 \mathrm{H}), 1.04(\mathrm{~d}, J=6.2 \mathrm{~Hz}, 3 \mathrm{H}), 1.59(\mathrm{~m}, 1 \mathrm{H}), 1.71-1.84(\mathrm{~m}, 4 \mathrm{H}), 2.08-2.36$ $(\mathrm{m}, 4 \mathrm{H}), 2.62(\mathrm{~m}, 1 \mathrm{H}), 2.88(\mathrm{dd}, J=7.3,13.6 \mathrm{~Hz}, 1 \mathrm{H}), 3.03(\mathrm{td}, J=10.3,4.4 \mathrm{~Hz}, 1 \mathrm{H}), 3.10(\mathrm{dd}, J=2.6,13.6$ $\mathrm{Hz}, 1 \mathrm{H}), 3.28(\mathrm{t}, J=9.2 \mathrm{~Hz}, 1 \mathrm{H}), 3.37(\mathrm{~s}, 6 \mathrm{H}), 3.72(\mathrm{~m}, 1 \mathrm{H}), 3.81(\mathrm{~s}, 3 \mathrm{H}), 3.86(\mathrm{~m}, 1 \mathrm{H}), 4.56(\mathrm{~d}, J=7.0 \mathrm{~Hz}$, 1H), $4.60(\mathrm{~d}, J=7.0 \mathrm{~Hz}, 1 \mathrm{H}), 4.68(\mathrm{~d}, J=7.0 \mathrm{~Hz}, 1 \mathrm{H}), 4.69$ (d, $J=7.0 \mathrm{~Hz}, 1 \mathrm{H}), 5.83-5.91(\mathrm{~m}, 2 \mathrm{H}), 6.35(\mathrm{~d}, J$ $=10.3 \mathrm{~Hz}, 1 \mathrm{H}) ;{ }^{13} \mathrm{C}-\mathrm{NMR}(68 \mathrm{MHz}) \delta 17.33,33.40,35.10,36.28,37.89,41.38,44.35,45.58,46.27,52.35$, 55.60, 71.59, 73.03, 83.65, 94.65, 94.91, 126.99, 127.05, 131.77, 137.70, 153.63, 164.72, 198.90 (1 carbon was not detected, but the structure was confirmed by a COSY analysis.); IR (neat) 3460, 2950, 1730, 1690, $1670,1615 \mathrm{~cm}^{-1}$; HRMS calcd for $\mathrm{C}_{24} \mathrm{H}_{36} \mathrm{O}_{8}\left(\mathrm{M}^{+}\right) \mathrm{m} / z$ 452.2410, found 452.2425.

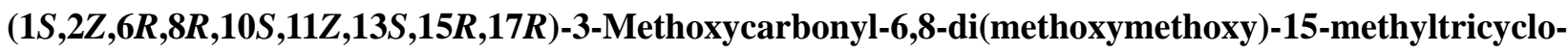 $\left[8.7 .0 .0^{13,17}\right]$ heptadeca-2,11-diene-4,14-dione (54)}

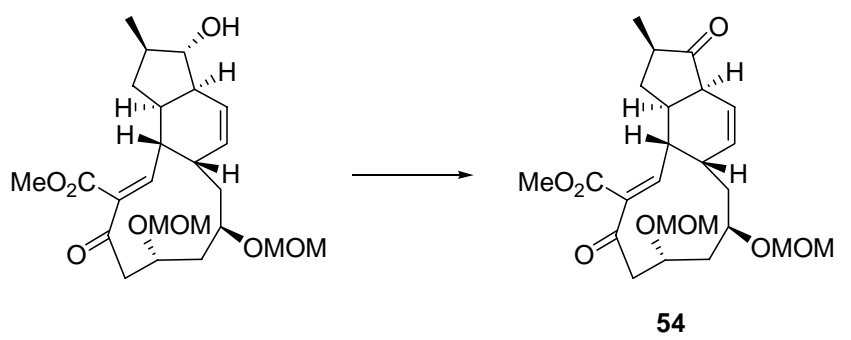

To a cooled $\left(0{ }^{\circ} \mathrm{C}\right)$, stirred solution of the secondary alcohol $(8.2 \mathrm{mg}, 0.018 \mathrm{mmol})$ in $\mathrm{CH}_{2} \mathrm{Cl}_{2}(1 \mathrm{~mL})$ was added Dess-Martin periodinane $(16.0 \mathrm{mg}, 0.035 \mathrm{mmol})$. The mixture was stirred for $2 \mathrm{~h}$ and then diluted with saturated aqueous $\mathrm{NaHCO}_{3}-20 \%$ aqueous $\mathrm{Na}_{2} \mathrm{~S}_{2} \mathrm{O}_{3}(1: 1,10 \mathrm{~mL})$ and $\mathrm{CH}_{2} \mathrm{Cl}_{2}(5 \mathrm{~mL})$ at $0{ }^{\circ} \mathrm{C}$. The mixture was stirred for $30 \mathrm{~min}$ and the organic layer was separated. The aqueous layer was extracted with $\mathrm{CH}_{2} \mathrm{Cl}_{2}$. The combined organic layers were dried and concentrated in vacuo. The residue was purified by column chromatography on silica gel (EtOAc/toluene, 1:1) to provide $8.1 \mathrm{mg}(99 \%)$ of $\mathbf{5 4}$ as a colorless oil; TLC, $\mathbf{R}_{f}$ 0.44 (acetone/toluene, 1:3); $[\alpha]^{25}{ }_{\mathrm{D}}+96\left(c 0.40, \mathrm{CHCl}_{3}\right) ;{ }^{1} \mathrm{H}-\mathrm{NMR}(270 \mathrm{MHz}) \delta 1.11(\mathrm{~d}, J=6.6 \mathrm{~Hz}, 3 \mathrm{H}), 1.45$ (m, 1H), $1.80(\mathrm{~m}, 1 \mathrm{H}), 1.97-2.12(\mathrm{~m}, 3 \mathrm{H}), 2.32(\mathrm{~m}, 2 \mathrm{H}), 2.54(\mathrm{~m}, 1 \mathrm{H}), 2.76-2.87(\mathrm{~m}, 2 \mathrm{H}), 2.95(\mathrm{~m}, 1 \mathrm{H}), 3.09$ $(\mathrm{m}, 1 \mathrm{H}), 3.23(\mathrm{~m}, 1 \mathrm{H}), 3.38(\mathrm{~s}, 6 \mathrm{H}), 3.56(\mathrm{~m}, 1 \mathrm{H}), 3.83(\mathrm{~s}, 3 \mathrm{H}), 4.01(\mathrm{~m}, 1 \mathrm{H}), 4.61(\mathrm{~d}, J=7.3 \mathrm{~Hz}, 1 \mathrm{H}), 4.62$ $(\mathrm{d}, J=7.0 \mathrm{~Hz}, 1 \mathrm{H}), 4.66(\mathrm{~d}, J=7.0 \mathrm{~Hz}, 1 \mathrm{H}), 4.70(\mathrm{~d}, J=7.3 \mathrm{~Hz}, 1 \mathrm{H}), 5.76-5.86(\mathrm{~m}, 2 \mathrm{H}), 6.53(\mathrm{~d}, J=10.6$ 
$\mathrm{Hz}, 1 \mathrm{H}) ;{ }^{13} \mathrm{C}-\mathrm{NMR}(68 \mathrm{MHz}) \delta 14.17,33.29,34.90,35.01,41.32,41.38,55.58,55.66,71.96,73.00,94.65$, 95.26, 124.23, 128.80, $138.02 \times 2,151.07 \times 2,198.29,217.64$ (4 carbons were not detected, but the structure was confirmed by ${ }^{1} \mathrm{H}-{ }^{1} \mathrm{H}$ COSY analysis.); IR (neat) 2940, 1730, 1680, $1640 \mathrm{~cm}^{-1}$; HRMS calcd for $\mathrm{C}_{24} \mathrm{H}_{34} \mathrm{O}_{8}$ $\left(\mathrm{M}^{+}\right) m / z$ 450.2253, found 450.2240.

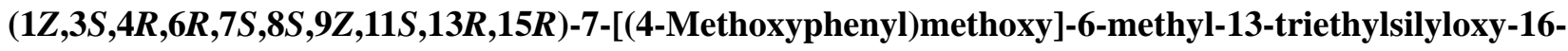 oxatetracyclo[13.2.2.0 $\left.0^{3,11} \cdot 0^{4,8}\right]$ nonadeca-1,9-diene-17,18-dione}

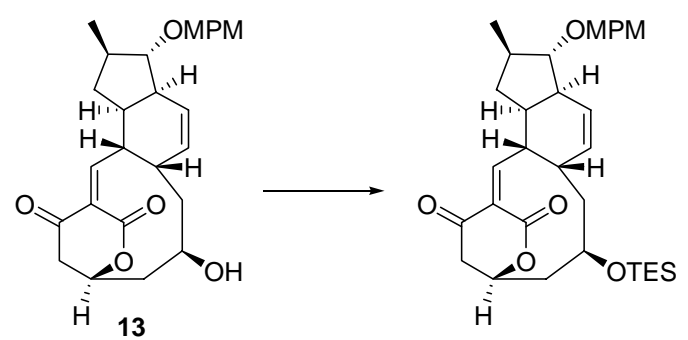

The following reaction was carried out under argon. To a cooled $\left(-78{ }^{\circ} \mathrm{C}\right)$, stirred solution of $\mathbf{1 3}(38.6 \mathrm{mg}$, $0.0853 \mathrm{mmol})$ in $\mathrm{CH}_{2} \mathrm{Cl}_{2}(4 \mathrm{~mL})$ were added 2,6-lutidine $(0.10 \mathrm{~mL}, 0.85 \mathrm{mmol})$ and TESOTf $(0.10 \mathrm{~mL}, 0.43$ mmol). The mixture was stirred at $-78{ }^{\circ} \mathrm{C}$ for $0.5 \mathrm{~h}$, and quenched with saturated aqueous $\mathrm{NaHCO}_{3}$. This was diluted with saturated aqueous $\mathrm{NaHCO}_{3}(10 \mathrm{~mL})$, and extracted with $\mathrm{CH}_{2} \mathrm{Cl}_{2}$. The combined organic layers were dried and concentrated in vacuo. The residue was purified by column chromatography on silica gel (EtOAc/hexane, 1:4) to provide $35.9 \mathrm{mg}(78 \%)$ of the TES ether as a colorless oil; TLC, $\mathrm{R}_{f} 0.33$ (EtOAc/hexane, 1:2); $[\alpha]^{23}{ }_{\mathrm{D}}+47\left(c \mathrm{c} .40, \mathrm{CHCl}_{3}\right) ;{ }^{1} \mathrm{H}-\mathrm{NMR}(270 \mathrm{MHz}) \delta$ 0.49-0.56 (m, 6H), 0.90-0.10 (m, 9H), $1.07(\mathrm{~d}, J=6.6 \mathrm{~Hz}, 3 \mathrm{H}), 1.25(\mathrm{q}, J=11.7 \mathrm{~Hz}, 1 \mathrm{H}), 1.62(\mathrm{~m}, 1 \mathrm{H}), 1.72(\mathrm{~m}, 1 \mathrm{H}), 1.82(\mathrm{~m}, 1 \mathrm{H}), 1.95-2.12$ $(\mathrm{m}, 2 \mathrm{H}), 2.39-2.54(\mathrm{~m}, 2 \mathrm{H}), 2.62(\mathrm{dd}, J=0.7,18.5 \mathrm{~Hz}, 1 \mathrm{H}), 2.77-2.89(\mathrm{~m}, 2 \mathrm{H}), 3.12(\mathrm{dd}, J=7.2,18.5 \mathrm{~Hz}$, $1 \mathrm{H}), 3.27(\mathrm{dd}, J=2.6,6.6 \mathrm{~Hz}, 1 \mathrm{H}), 3.31(\mathrm{~m}, 1 \mathrm{H}), 3.68(\mathrm{~m}, 1 \mathrm{H}), 3.81(\mathrm{~s}, 3 \mathrm{H}), 4.45,4.57(2 \mathrm{~d}, J=11.2 \mathrm{~Hz}$, $1 \mathrm{H} \times 2), 4.87(\mathrm{~m}, 1 \mathrm{H}), 5.65(\mathrm{~d}, J=10.4 \mathrm{~Hz}, 1 \mathrm{H}), 5.71(\mathrm{~d}, J=10.4 \mathrm{~Hz}, 1 \mathrm{H}), 6.90(\mathrm{~m}, 3 \mathrm{H}), 7.30(\mathrm{~m}, 2 \mathrm{H})$; ${ }^{13} \mathrm{C}-\mathrm{NMR}(68 \mathrm{MHz}) \delta 5.35 \times 3,6.88 \times 3,18.86,35.56 \times 2,37.64,39.65,39.82,41.47,41.81,42.30,45.61$, $55.26,67.79,71.59,72.77,92.61,113.80 \times 2,125.52,129.27 \times 2,130.27,130.59,135.86,157.23,159.16$, 165.75, 194.03; IR (neat) 2950, 1740, 1715, 1615, $1515 \mathrm{~cm}^{-1}$; HRMS calcd for $\mathrm{C}_{33} \mathrm{H}_{46} \mathrm{O}_{6} \mathrm{Si}\left(\mathrm{M}^{+}\right) \mathrm{m} / \mathrm{z}$ 566.3064 , found 566.3061 .

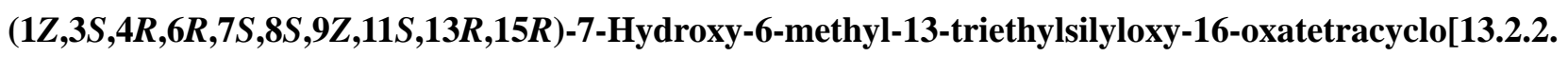
$\left.0^{3,11} .0^{4,8}\right]$ nonadeca-1,9-diene-17,18-dione (56) 


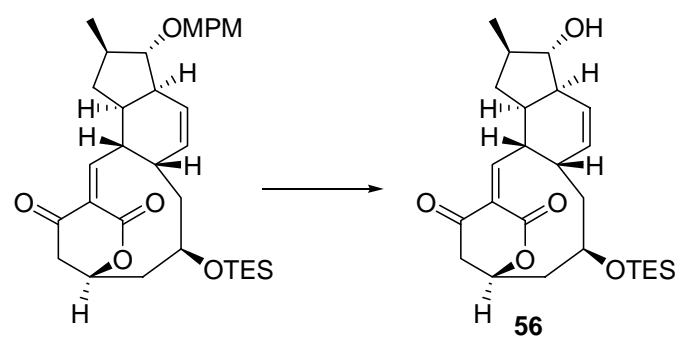

To a stirred solution of the MPM ether $(35.9 \mathrm{mg}, 0.0633 \mathrm{mmol})$ in $\mathrm{CH}_{2} \mathrm{Cl}_{2}(4 \mathrm{~mL})$ was added aqueous phosphate buffer $(0.4 \mathrm{~mL}, \mathrm{pH}$ 7). This was stirred for $30 \mathrm{~min}$ and then DDQ (22.4 $\mathrm{mg}, 0.0985 \mathrm{mmol})$ was added at $0{ }^{\circ} \mathrm{C}$. The mixture was stirred for $3.5 \mathrm{~h}$ and then DDQ $(18.9 \mathrm{mg}, 0.0831 \mathrm{mmol})$ was added at $0{ }^{\circ} \mathrm{C}$. The mixture was stirred for $2 \mathrm{~h}$ and then quenched with saturated aqueous $\mathrm{NaHCO}_{3}$. This was diluted with saturated aqueous $\mathrm{NaHCO}_{3}(15 \mathrm{~mL})$, and extracted with $\mathrm{CH}_{2} \mathrm{Cl}_{2}$. The combined organic layers were dried and concentrated in vacuo. The residue was purified by column chromatography on silica gel (EtOAc/hexane, 1:3 to $1: 1)$ to provide $26.1 \mathrm{mg}(92 \%)$ of $\mathbf{5 6}$ as a colorless oil; TLC, $\mathrm{R}_{f} 0.30$ (EtOAc/hexane, $\left.1: 1\right) ;[\alpha]^{22}+65.9(c$ 0.33, $\left.\mathrm{CHCl}_{3}\right) ;{ }^{1} \mathrm{H}-\mathrm{NMR}(270 \mathrm{MHz}) \delta$ 0.49-0.58 (m, 6H), 0.89-0.95 (m, 9H), $1.07(\mathrm{~d}, J=6.6 \mathrm{~Hz}, 3 \mathrm{H}), 1.25$ $(\mathrm{m}, 1 \mathrm{H}), 1.61-1.87(\mathrm{~m}, 3 \mathrm{H}), 2.08(\mathrm{~m}, 1 \mathrm{H}), 2.40-2.66(\mathrm{~m}, 4 \mathrm{H}), 2.62(\mathrm{dd}, J=0.7,18.7 \mathrm{~Hz}, 1 \mathrm{H}), 2.80(\mathrm{~m}, 1 \mathrm{H})$, $3.12(\mathrm{ddd}, J=0.7,7.3,18.7 \mathrm{~Hz}, 1 \mathrm{H}), 3.28(\mathrm{ddd}, J=1.5,5.9,11.4 \mathrm{~Hz}, 1 \mathrm{H}), 3.44(\mathrm{dd}, J=4.0,6.6 \mathrm{~Hz}, 1 \mathrm{H})$, $3.69(\mathrm{~m}, 1 \mathrm{H}), 4.87(\mathrm{~m}, 1 \mathrm{H}), 5.74(\mathrm{~d}, J=10.4 \mathrm{~Hz}, 1 \mathrm{H}), 5.85(\mathrm{dt}, J=10.4,2.9 \mathrm{~Hz}, 1 \mathrm{H}), 6.86(\mathrm{~d}, J=11.4 \mathrm{~Hz}$, $1 \mathrm{H}) ;{ }^{13} \mathrm{C}-\mathrm{NMR}(68 \mathrm{MHz}) \delta 5.35 \times 3,6.88 \times 3,17.94,35.53,35.73,36.69,40.20,41.41,41.81,42.33,44.29$, 45.64, 67.81, 72.80, 86.47, 125.18, 125.44, 129.90, 157.11, 165.75, 193.97; IR (neat) 3440, 2950, 1730, 1715, $1615 \mathrm{~cm}^{-1}$; HRMS calcd for $\mathrm{C}_{25} \mathrm{H}_{38} \mathrm{O}_{5} \mathrm{Si}\left(\mathrm{M}^{+}\right) \mathrm{m} / z$ 446.2489, found 446.2497 .

$(1 Z, 3 S, 4 R, 6 R, 8 S, 9 Z, 11 S, 13 R, 15 R)-6-M e t h y l-13-t r i e t h y l s i l y l o x y-16-o x a t e t r a c y c l o\left[13.2 .2 .0^{3,11} \cdot 0^{4,8}\right]$ nonadeca-1,9-diene-7,17,18-trione

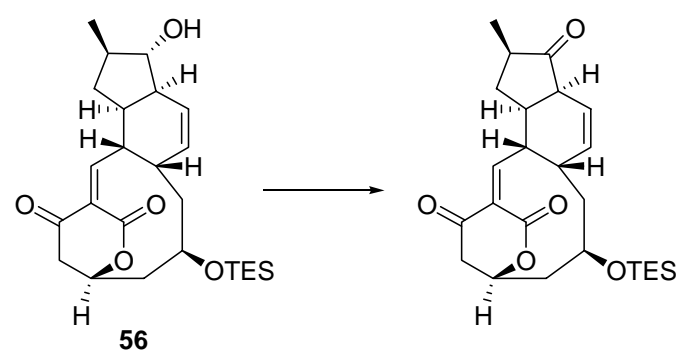

To a cooled $\left(0{ }^{\circ} \mathrm{C}\right)$, stirred solution of $\mathbf{5 6}(23.5 \mathrm{mg}, 0.0526 \mathrm{mmol})$ in $\mathrm{CH}_{2} \mathrm{Cl}_{2}(3 \mathrm{~mL})$ were added $\mathrm{NaHCO}_{3}$ (14.4 mg, $0.171 \mathrm{mmol}$ ) and Dess-Martin periodinane $(34.4 \mathrm{mg}, 0.0810 \mathrm{mmol})$. The mixture was stirred for $1.5 \mathrm{~h}$ and then diluted with saturated aqueous $\mathrm{NaHCO}_{3}-20 \%$ aqueous $\mathrm{Na}_{2} \mathrm{~S}_{2} \mathrm{O}_{3}(1: 1,10 \mathrm{~mL})$ and $\mathrm{CH}_{2} \mathrm{Cl}_{2}(5$ $\mathrm{mL}$ ) at $0{ }^{\circ} \mathrm{C}$. The mixture was stirred for $30 \mathrm{~min}$ and then the organic layer was separated. The aqueous layer 
was extracted with $\mathrm{CH}_{2} \mathrm{Cl}_{2}$. The combined organic layers were dried and concentrated in vacuo. The residue was purified by column chromatography on silica gel (EtOAc/hexane, 1:3) to provide $22.0 \mathrm{mg}(94 \%)$ of the ketone as a colorless oil; TLC, $\mathrm{R}_{f} 0.55$ (EtOAc/hexane, 1:1); $[\alpha]^{23}{ }_{\mathrm{D}}+182\left(c 0.26, \mathrm{CHCl}_{3}\right) ;{ }^{1} \mathrm{H}-\mathrm{NMR}(270$ MHz) $\delta$ 0.47-0.56 (m, 6H), 0.88-0.94 (m, 9H), $1.11(\mathrm{~d}, J=6.6 \mathrm{~Hz}, 3 \mathrm{H}), 1.47(\mathrm{q}, J=12.1 \mathrm{~Hz}, 1 \mathrm{H}), 1.68-1.74$ $(\mathrm{m}, 2 \mathrm{H}), 2.12(\mathrm{dt}, J=16.5,6.6 \mathrm{~Hz}, 1 \mathrm{H}), 2.21-2.35(\mathrm{~m}, 2 \mathrm{H}), 2.46(\mathrm{ddd}, J=4.2,11.5,15.6 \mathrm{~Hz}, 1 \mathrm{H}), 2.63(\mathrm{~m}$, $1 \mathrm{H}), 2.64(\mathrm{dd}, J=0.7,18.7 \mathrm{~Hz}, 1 \mathrm{H}), 2.88(\mathrm{~m}, 1 \mathrm{H}), 3.14(\mathrm{ddd}, J=0.7,7.3,18.7 \mathrm{~Hz}, 1 \mathrm{H}), 3.15(\mathrm{~m}, 1 \mathrm{H}), 3.44$ $(\mathrm{ddd}, J=2.2,6.2,11.7 \mathrm{~Hz}, 1 \mathrm{H}), 3.67(\mathrm{~m}, 1 \mathrm{H}), 4.89(\mathrm{~m}, 1 \mathrm{H}), 5.66(\mathrm{dt}, J=10.3,3.1 \mathrm{~Hz}, 1 \mathrm{H}), 5.88(\mathrm{dt}, J=10.3$, $2.2 \mathrm{~Hz}, 1 \mathrm{H}), 6.81(\mathrm{~d}, J=11.7 \mathrm{~Hz}, 1 \mathrm{H}) ;{ }^{13} \mathrm{C}-\mathrm{NMR}(68 \mathrm{MHz}) \delta 5.33 \times 3,6.85 \times 3,13.96,33.17,34.67,35.53$, 38.56, 41.47, 41.98, 43.88, 45.53, 45.67, 67.70, 72.85, 123.02, 128.32, 136.32, 155.36, 165.67, 193.91, 217.13; IR (neat) 2960, 1740, 1700, $1620 \mathrm{~cm}^{-1}$; HRMS calcd for $\mathrm{C}_{25} \mathrm{H}_{36} \mathrm{O}_{5} \mathrm{Si}\left(\mathrm{M}^{+}\right) \mathrm{m} / z$ 444.2332, found 444.2331 .

\section{(+)-Macquarimicin A (1)}
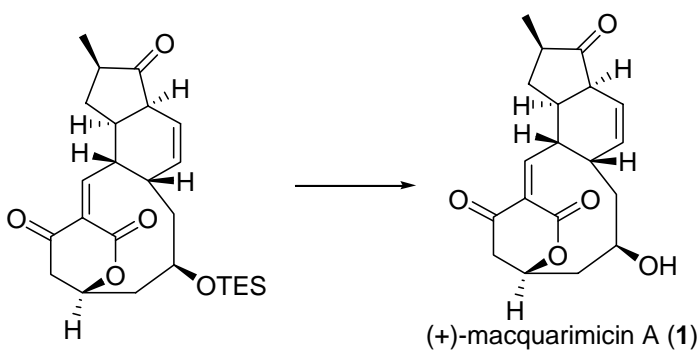

To a cooled $\left(0{ }^{\circ} \mathrm{C}\right)$, stirred solution of the TES ether $(22.0 \mathrm{mg}, 0.0495 \mathrm{mmol})$ in $\mathrm{MeOH}(3 \mathrm{~mL})$ was added PPTS $(1.0 \mathrm{mg}, 0.0040 \mathrm{mmol})$. The mixture was stirred for $2 \mathrm{~h}$ and then $\mathrm{NaHCO}_{3}(6.0 \mathrm{mg}, 0.071 \mathrm{mmol})$ was added at $0{ }^{\circ} \mathrm{C}$. This was azeotroped with EtOAc and the residue was purified by column chromatography on silica gel (EtOAc/toluene, 1:1) to provide $15.8 \mathrm{mg}(97 \%)$ of macquarimicin A (1) as an amorphous solid; TLC, $\mathrm{R}_{f} 0.45$ (acetone/toluene, 2:3); $[\alpha]^{23}{ }_{\mathrm{D}}+270(c 0.20, \mathrm{MeOH}),[\alpha]^{23}{ }_{\mathrm{D}}+285(c 0.780, \mathrm{MeOH}) ;{ }^{1} \mathrm{H}-\mathrm{NMR}$ $(270 \mathrm{MHz}) \delta 1.11(\mathrm{~d}, J=6.6 \mathrm{~Hz}, 3 \mathrm{H}), 1.48(\mathrm{q}, J=12.1 \mathrm{~Hz}, 1 \mathrm{H}), 1.75-1.81(\mathrm{~m}, 2 \mathrm{H}), 2.01(\mathrm{dt}, J=16.9,6.6$ $\mathrm{Hz}, 1 \mathrm{H}), 2.19-2.36(\mathrm{~m}, 2 \mathrm{H}), 2.51(\mathrm{ddd}, J=4.0,11.7,15.4 \mathrm{~Hz}, 1 \mathrm{H}), 2.64(\mathrm{~m}, 1 \mathrm{H}), 2.68(\mathrm{dd}, J=0.7,19.1 \mathrm{~Hz}$, $1 \mathrm{H}), 2.90(\mathrm{~m}, 1 \mathrm{H}), 3.15(\mathrm{ddd}, J=0.9,7.5,19.1 \mathrm{~Hz}, 1 \mathrm{H}), 3.15(\mathrm{~m}, 1 \mathrm{H}), 3.46(\mathrm{ddd}, J=2.3,6.0,11.4 \mathrm{~Hz}, 1 \mathrm{H})$, $3.65(\mathrm{~m}, 1 \mathrm{H}), 4.92(\mathrm{~m}, 1 \mathrm{H}), 5.67(\mathrm{dt}, J=10.3,2.9 \mathrm{~Hz}, 1 \mathrm{H}), 5.91(\mathrm{dt}, J=10.3,2.0 \mathrm{~Hz}, 1 \mathrm{H}), 6.80(\mathrm{~d}, J=11.4$ $\mathrm{Hz}, 1 \mathrm{H}) ;{ }^{13} \mathrm{C}-\mathrm{NMR}(68 \mathrm{MHz}) \delta 13.91,33.17,34.67,35.25,38.64,40.86,41.26,43.88,45.64,45.70,66.81$, 72.77, 123.68, 127.57, 136.44, 155.15, 165.64, 194.12, 217.04; IR (neat) 3450, 2930, 1735, 1705, $1620 \mathrm{~cm}^{-1}$; HRMS calcd for $\mathrm{C}_{19} \mathrm{H}_{22} \mathrm{O}_{5}\left(\mathrm{M}^{+}\right) \mathrm{m} / z 330.1467$, found 330.1457 .

\section{(+)-Macquarimicin B (2)}



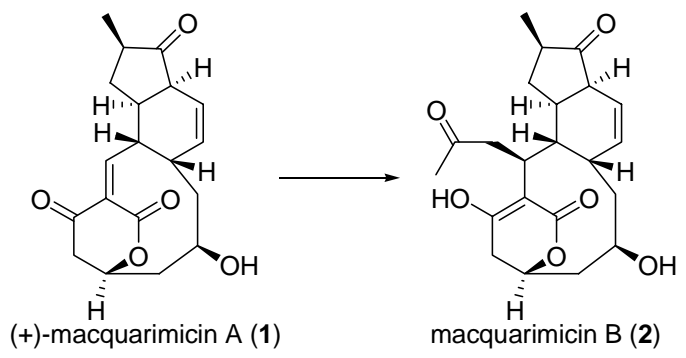

To a cooled $\left(0^{\circ} \mathrm{C}\right)$, stirred solution of $1(7.6 \mathrm{mg}, 0.0230 \mathrm{mmol})$ in THF- $\mathrm{H}_{2} \mathrm{O}(5: 1,1 \mathrm{~mL})$ was added isopropenyl methyl ether $(0.2 \mathrm{~mL})$. The mixture was stirred for $3 \mathrm{~h}$, and azeotroped with acetone. The residue was purified by column chromatography on silica gel (acetone/toluene, 1:2 to acetone) to provide $7.4 \mathrm{mg}$ $(83 \%)$ of the (+)-macquarimicin B (2) as white powder; TLC, $\mathrm{R}_{f} 0.30$ (acetone/toluene, 1:1); $[\alpha]^{25}+325(c$ 0.25, MeOH); ${ }^{1} \mathrm{H}-\mathrm{NMR}(300 \mathrm{MHz}) \delta 1.09(\mathrm{~d}, J=6.6 \mathrm{~Hz}, 3 \mathrm{H}), 1.49(\mathrm{q}, J=12.2 \mathrm{~Hz}, 1 \mathrm{H}), 1.74(\mathrm{~d}, J=14.9 \mathrm{~Hz}$, 1H), 1.84 (d, $J=17.1 \mathrm{~Hz}, 1 \mathrm{H}), 1.98$ (ddd, $J=5.1,9.5,17.1 \mathrm{~Hz}, 1 \mathrm{H}), 2.09-2.28$ (m, 3H), 2.21 (s, 3H), 2.34 (d, $J=18.0 \mathrm{~Hz}, 1 \mathrm{H}), 2.43-2.53(\mathrm{~m}, 2 \mathrm{H}), 2.77(\mathrm{~m}, 1 \mathrm{H}), 2.89-3.01(\mathrm{~m}, 4 \mathrm{H}), 3.49$ (dd, $J=10.5,20.0 \mathrm{~Hz}, 1 \mathrm{H}), 3.84$ $(\mathrm{m}, 1 \mathrm{H}), 4.60(\mathrm{~m}, 1 \mathrm{H}), 5.63(\mathrm{dt}, J=10.6,3.4 \mathrm{~Hz}, 1 \mathrm{H}), 6.01(\mathrm{~d}, J=10.6 \mathrm{~Hz}, 1 \mathrm{H}), 9.11(\mathrm{~s}, 1 \mathrm{H}) ;{ }^{13} \mathrm{C}-\mathrm{NMR}(68$ MHz) $\delta 13.99,28.62,30.12,31.59,31.85,34.44,36.40,38.15,40.57,43.51,45.24,46.22$, 46.36, 67.84, 71.53, 106.60, 122.96, 128.72, 164.48, 167.19, 214.30, 217.79; IR (KBr disk) 3530, 3130, 1725, 1685, 1660, $1635 \mathrm{~cm}^{-1}$; HRMS calcd for $\mathrm{C}_{22} \mathrm{H}_{28} \mathrm{O}_{6}\left(\mathrm{M}^{+}\right) \mathrm{m} / \mathrm{z} 388.1886$, found 388.1893 .

\section{(+)-Macquarimicin C (3)}
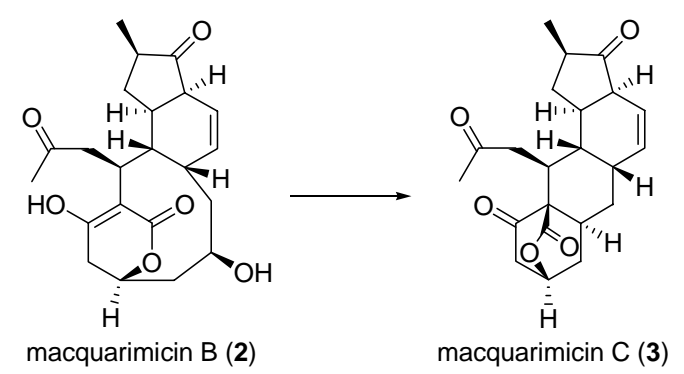

To a cooled $\left(0^{\circ} \mathrm{C}\right)$, stirred solution of $2(1.9 \mathrm{mg}, 0.0049 \mathrm{mmol})$ in $\mathrm{CH}_{2} \mathrm{Cl}_{2}(1 \mathrm{~mL})$ was added CSA (1.0 mg, $0.0043 \mathrm{mmol})$. The mixture was stirred for $2 \mathrm{~h}$ and CSA $(3.0 \mathrm{mg}, 0.013 \mathrm{mmol})$ was added. This was stirred for $7.5 \mathrm{~h}$ and CSA $(1.5 \mathrm{mg}, 0.0065 \mathrm{mmol})$ was added. This was stirred for $2 \mathrm{~h}$ and quenched with saturated aqueous $\mathrm{NaHCO}_{3}$. This was diluted with saturated aqueous $\mathrm{NaHCO}_{3}(10 \mathrm{~mL})$ and extracted with $\mathrm{CH}_{2} \mathrm{Cl}_{2}$. The combined organic layers were dried and concentrated in vacuo. The residue was purified by column chromatography on silica gel (acetone/toluene, 1:5) to provide $1.9 \mathrm{mg}$ (quant.) of (+)-macquarimicin $\mathrm{C} \mathrm{(3)}$ as an amorphous solid. TLC, $\mathrm{R}_{f} 0.53$ (acetone/toluene, 1:1); $[\alpha]^{24}{ }_{\mathrm{D}}+250(c 0.25, \mathrm{MeOH}) ;{ }^{1} \mathrm{H}-\mathrm{NMR}(270 \mathrm{MHz})$ $\delta 1.06(\mathrm{~d}, J=6.6 \mathrm{~Hz}, 3 \mathrm{H}), 1.39(\mathrm{q}, J=12.0 \mathrm{~Hz}, 1 \mathrm{H}), 1.59(\mathrm{~m}, 1 \mathrm{H}), 1.85(\mathrm{~m}, 1 \mathrm{H}), 1.90(\mathrm{~d}, J=14.0 \mathrm{~Hz}, 1 \mathrm{H})$, 
2.01-2.22 (m, 6H), $2.13(\mathrm{~s}, 3 \mathrm{H}), 2.42(\mathrm{dd}, J=2.2,19.3 \mathrm{~Hz}, 1 \mathrm{H}), 2.45(\mathrm{dd}, J=1.2,19.0 \mathrm{~Hz}, 1 \mathrm{H}), 2.48(\mathrm{~m}$, 1H), $2.66(\mathrm{~m}, 1 \mathrm{H}), 2.71(\mathrm{dt}, J=19.0,3.2 \mathrm{~Hz}, 1 \mathrm{H}), 2.82(\mathrm{dd}, J=5.9,19.3 \mathrm{~Hz}, 1 \mathrm{H}), 3.28(\mathrm{~m}, 1 \mathrm{H}), 4.98(\mathrm{~m}, 1 \mathrm{H})$, $5.34(\mathrm{~d}, J=10.0 \mathrm{~Hz}, 1 \mathrm{H}), 5.73(\mathrm{dt}, J=10.0,3.3 \mathrm{~Hz}, 1 \mathrm{H}) ;{ }^{13} \mathrm{C}-\mathrm{NMR}(75 \mathrm{MHz}) \delta 13.88,28.26,29.89,30.30$, 31.88, 33.36, 34.08, 34.59, 36.89, 37.90, 41.91, 43.77, 46.30, 48.38, 65.89, 73.10, 125.94, 128.68, 169.36, 202.89, 206.75, 218.53; IR (neat) 2930, 1730, 1650, $\mathrm{cm}^{-1}$; HRMS calcd for $\mathrm{C}_{22} \mathrm{H}_{26} \mathrm{O}_{5}\left(\mathrm{M}^{+}\right) \mathrm{m} / z$ 370.1780, found 370.1777 .

\section{6-O-TES-9-epi-cochleamycin A}

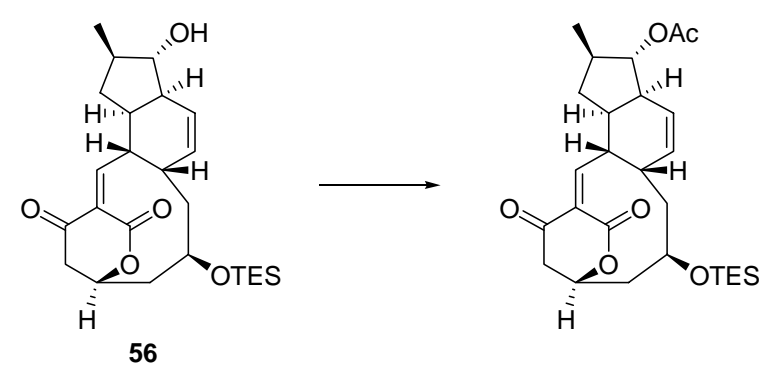

To a cooled $\left(-18{ }^{\circ} \mathrm{C}\right)$, stirred solution of $\mathbf{5 6}(10.4 \mathrm{mg}, 0.0233 \mathrm{mmol})$ in $\mathrm{CH}_{2} \mathrm{Cl}_{2}(1 \mathrm{~mL})$ were added $\mathrm{Ac}_{2} \mathrm{O}$ $(0.010 \mathrm{~mL}, 0.11 \mathrm{mmol})$ and 4-dimethylaminopyridine $(4.3 \mathrm{mg}, 0.035 \mathrm{mmol})$. The mixture was stirred for 1.5 $\mathrm{h}$ and then filtered through a pad of silica gel. The filtrate was concentrated in vacuo and the residue was purified by column chromatography on silica gel (EtOAc/hexane, 1:2) to provide $10.7 \mathrm{mg}$ (94\%) of 16-O-TES-9-epi-cochleamycin A as a colorless oil; TLC, $\mathrm{R}_{f} 0.69$ (EtOAc/hexane, 1:2); $[\alpha]^{21}{ }_{\mathrm{D}}+44.9(c 0.535$, $\left.\mathrm{CHCl}_{3}\right) ;{ }^{1} \mathrm{H}-\mathrm{NMR}(270 \mathrm{MHz}) \delta 0.52(\mathrm{q}, J=7.8 \mathrm{~Hz}, 6 \mathrm{H}), 0.91(\mathrm{t}, J=7.8 \mathrm{~Hz}, 9 \mathrm{H}), 1.07$ (d, $\left.J=7.0 \mathrm{~Hz}, 3 \mathrm{H}\right)$, $1.30(\mathrm{q}, J=11.7 \mathrm{~Hz}, 1 \mathrm{H}), 1.60-1.74(\mathrm{~m}, 2 \mathrm{H}), 1.88(\mathrm{~m}, 1 \mathrm{H}), 2.02-2.19(\mathrm{~m}, 2 \mathrm{H}), 2.09(\mathrm{~s}, 3 \mathrm{H}), 2.33-2.56(\mathrm{~m}$, 2H), $2.62(\mathrm{~d}, J=18.7 \mathrm{~Hz}, 1 \mathrm{H}), 2.70(\mathrm{~m}, 1 \mathrm{H}), 2.84(\mathrm{~m}, 1 \mathrm{H}), 3.12(\mathrm{dd}, J=6.8,18.7 \mathrm{~Hz}, 1 \mathrm{H}), 3.34$ (ddd, $J=2.2$, $5.5,11.4 \mathrm{~Hz}, 1 \mathrm{H}), 3.65(\mathrm{dd}, J=6.2,10.3 \mathrm{~Hz}, 1 \mathrm{H}), 4.46(\mathrm{dd}, J=2.2,6.2 \mathrm{~Hz}, 1 \mathrm{H}), 4.87(\mathrm{~m}, 1 \mathrm{H}), 5.75(\mathrm{br} \mathrm{d}, J=$ 10.6, 1H), $5.89(\mathrm{~m}, 1 \mathrm{H}), 6.83(\mathrm{~d}, J=11.4 \mathrm{~Hz}, 1 \mathrm{H}) ;{ }^{13} \mathrm{C}-\mathrm{NMR}(68 \mathrm{MHz}) \delta 5.33 \times 3,6.88 \times 3,18.51,21.28$, 35.33, 35.50, 37.95, 38.87, 39.31, 41.44, 42.24, 42.82, 45.61, 67.73, 72.82, 86.76, 126.16, 128.86, 136.06, 156.68, 165.72, 171.37, 194.09; IR (neat) 2960, 1740, 1710, $1610 \mathrm{~cm}^{-1}$; HRMS calcd for $\mathrm{C}_{27} \mathrm{H}_{40} \mathrm{O}_{6} \mathrm{Si}\left(\mathrm{M}^{+}\right)$ $\mathrm{m} / \mathrm{z}$ 488.2594, found 488.2596 .

\section{9-Epi-cochleamycin A (57)}
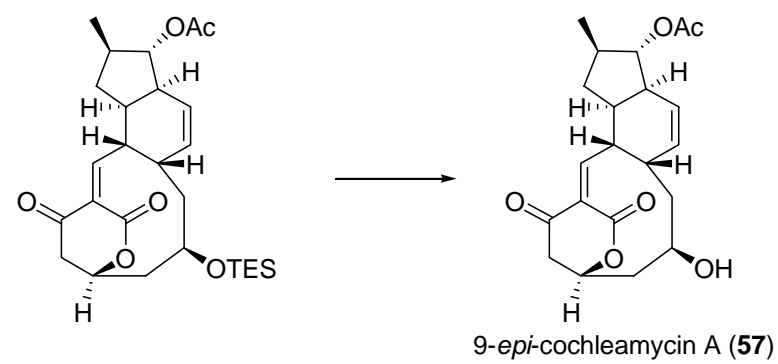

To a cooled $\left(0{ }^{\circ} \mathrm{C}\right)$, stirred solution of 16-O-TES-9-epi-cochleamycin A $(10.7 \mathrm{mg}, 0.0219 \mathrm{mmol})$ in $\mathrm{MeOH}(1$ 
$\mathrm{mL})$ was added PPTS $(1.7 \mathrm{mg}, 0.0066 \mathrm{mmol})$. The mixture was stirred for $4 \mathrm{~h}$ and then $\mathrm{NaHCO}_{3}(10.0 \mathrm{mg}$, $0.119 \mathrm{mmol}$ ) was added at $0{ }^{\circ} \mathrm{C}$. This was azeotroped with EtOAc and the residue was purified by column chromatography on silica gel (EtOAc/toluene, 1:1) to provide $8.2 \mathrm{mg}$ (quant.) of 9-epi-cochleamycin A (57) as an amorphous solid; TLC, $\mathrm{R}_{f} 0.38$ (acetone/toluene, 1:2); $[\alpha]^{21}{ }_{\mathrm{D}}+42\left(c 0.44, \mathrm{CHCl}_{3}\right) ;{ }^{1} \mathrm{H}-\mathrm{NMR}(300 \mathrm{MHz})$ $\delta 1.07(\mathrm{~d}, J=6.6 \mathrm{~Hz}, 3 \mathrm{H}), 1.31(\mathrm{q}, J=11.8 \mathrm{~Hz}, 1 \mathrm{H}), 1.71(\mathrm{~d}, J=17.3 \mathrm{~Hz}, 1 \mathrm{H}), 1.79(\mathrm{~d}, J=15.6 \mathrm{~Hz}, 1 \mathrm{H})$, 1.85-2.12 (m, 4H), $2.08(\mathrm{~s}, 3 \mathrm{H}), 2.44-2.56(\mathrm{~m}, 2 \mathrm{H}), 2.68(\mathrm{~d}, J=18.7 \mathrm{~Hz}, 1 \mathrm{H}), 2.69(\mathrm{~m}, 1 \mathrm{H}), 2.87(\mathrm{~m}, 1 \mathrm{H})$, $3.13(\mathrm{dd}, J=7.4,18.7 \mathrm{~Hz}, 1 \mathrm{H}), 3.36(\mathrm{dd}, J=5.8,11.1 \mathrm{~Hz}, 1 \mathrm{H}), 3.64(\mathrm{~m}, 1 \mathrm{H}), 4.45(\mathrm{~d}, J=6.3 \mathrm{~Hz}, 1 \mathrm{H}), 4.90$ $(\mathrm{m}, 1 \mathrm{H}), 5.78(\mathrm{br} \mathrm{d}, J=10.4,1 \mathrm{H}), 5.90(\mathrm{br} \mathrm{d}, J=10.4 \mathrm{~Hz}, 1 \mathrm{H}), 6.82(\mathrm{~d}, J=11.1 \mathrm{~Hz}, 1 \mathrm{H}) ;{ }^{13} \mathrm{C}-\mathrm{NMR}(68$ MHz) $\delta 18.49,21.25,35.22,35.30,37.95,38.93,39.33,41.24 \times 2,42.76,45.55,66.84,72.77,86.65,125.49$, 129.61, 136.15, 156.48, 165.69, 171.28, 194.29; IR (neat) 3450, 2930, 1710, 1705, $1620 \mathrm{~cm}^{-1}$; HRMS calcd for $\mathrm{C}_{21} \mathrm{H}_{26} \mathrm{O}_{6}\left(\mathrm{M}^{+}\right) \mathrm{m} / z$ 374.1729, found 374.1723 .

\section{9-Epi-cochleamycin B (58)}
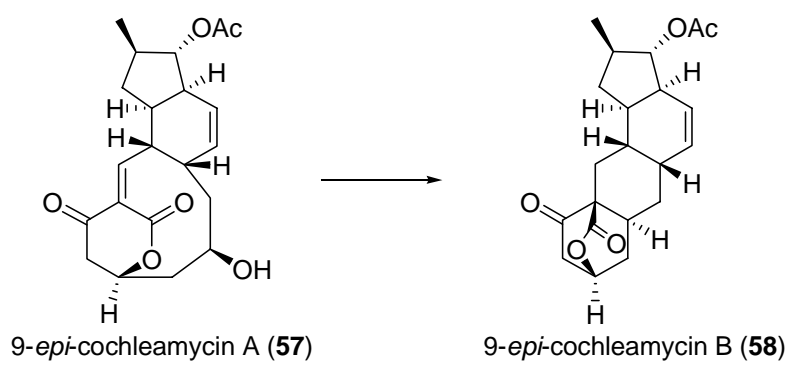

To a cooled $\left(0{ }^{\circ} \mathrm{C}\right)$, stirred solution of $\mathbf{5 7}(4.0 \mathrm{mg}, 0.011 \mathrm{mmol})$ in $\mathrm{MeOH}(1 \mathrm{~mL})$ were added $\mathrm{NaBH}_{4}(4.0 \mathrm{mg}$, $0.11 \mathrm{mmol})$. The mixture was stirred for $6 \mathrm{~h}$ and then quenched with sat. aq. $\mathrm{NH}_{4} \mathrm{Cl}(1 \mathrm{~mL})$. This was diluted with brine and extracted with $\mathrm{CH}_{2} \mathrm{Cl}_{2}$. The combined organic layers were dried and concentrated in vacuo to give a crude product, which was immediately used in the next step without purification. To a cooled $\left(0{ }^{\circ} \mathrm{C}\right)$, stirred solution of the product obtained above in $\mathrm{CH}_{2} \mathrm{Cl}_{2}(1 \mathrm{~mL})$ were added $\mathrm{CSA}(0.5 \mathrm{mg}, 0.002 \mathrm{mmol})$. The mixture was stirred for $1 \mathrm{~h}$ and then quenched with $\mathrm{pH} 7$ phosphate buffer $(1 \mathrm{~mL})$. This was diluted with brine and extracted with $\mathrm{CH}_{2} \mathrm{Cl}_{2}$. The combined organic layers were dried and concentrated in vacuo. The residue was purified by column chromatography on silica gel (EtOAc/hexane, 1:2) to provide $2.7 \mathrm{mg}(71 \%)$ of 9-epi-cochleamycin B (58) as an amorphous solid; TLC, $\mathrm{R}_{f} 0.61$ (acetone/toluene, 1:1); $[\alpha]^{21}{ }_{\mathrm{D}}+73(c 0.14$, $\left.\mathrm{CHCl}_{3}\right) ;{ }^{1} \mathrm{H}-\mathrm{NMR}(300 \mathrm{MHz}) \delta 1.04(\mathrm{~d}, J=6.8 \mathrm{~Hz}, 3 \mathrm{H}), 1.21(\mathrm{q}, J=12.0 \mathrm{~Hz}, 1 \mathrm{H}), 1.45(\mathrm{dt}, J=4.5,13.2 \mathrm{~Hz}$, $1 \mathrm{H}), 1.68(\mathrm{t}, J=13.5 \mathrm{~Hz}, 1 \mathrm{H}), 1.76-1.94(\mathrm{~m}, 4 \mathrm{H}), 1.98-2.12(\mathrm{~m}, 2 \mathrm{H}), 2.07(\mathrm{~s}, 3 \mathrm{H}), 2.15-2.30(\mathrm{~m}, 3 \mathrm{H})$, 2.37-2.52 (m, 3H), $2.73(\mathrm{dt}, J=19.3,3.0 \mathrm{~Hz}, 1 \mathrm{H}), 4.38$ (dd, $J=2.7,6.3 \mathrm{~Hz}, 1 \mathrm{H}), 4.99(\mathrm{~m}, 1 \mathrm{H}), 5.27$ (br d, $J$ $=10.2,1 \mathrm{H}), 5.90(\mathrm{dt}, J=10.2,2.7 \mathrm{~Hz}, 1 \mathrm{H}) ;{ }^{13} \mathrm{C}-\mathrm{NMR}(68 \mathrm{MHz}) \delta 18.46,21.31,24.53,29.57,30.38,30.55$, 33.14, 35.68, 38.04, 38.93, 41.32, 41.75, 42.99, 60.13, 73.03, 86.99, 127.16, 130.27, 170.10, 171.37, 203.42; IR (neat) 2925, 1765, 1735, $1720 \mathrm{~cm}^{-1}$; HRMS (FAB) calcd for $\mathrm{C}_{21} \mathrm{H}_{27} \mathrm{O}_{5}\left(\mathrm{M}^{+}+\mathrm{H}\right) \mathrm{m} / z .359 .1859$, found 
359.1853. 


\section{Determination of Stereochemistry}

\subsection{Stereochemistry of syn-1,3-Diol $\mathbf{2 1}$}

Stereochemistry of $\mathbf{2 1}$ was determined to be syn based on the ${ }^{13} \mathrm{C}-\mathrm{NMR}$ analysis of its acetonide, of which synthesis is shown below (Scheme S3). The ${ }^{13} \mathrm{C}$-NMR shifts of newly formed $\left(\mathrm{CH}_{3}\right)_{2} \mathrm{C}=$ were $\delta 19.64$ and $29.86 \mathrm{ppm}$. As the difference of the two methyl shifts was $10.22 \mathrm{ppm}$, we assigned 21 to be syn-isomers based on the empirical rule reported by Rychnovsky et al. ${ }^{7}$

\section{Scheme S3}

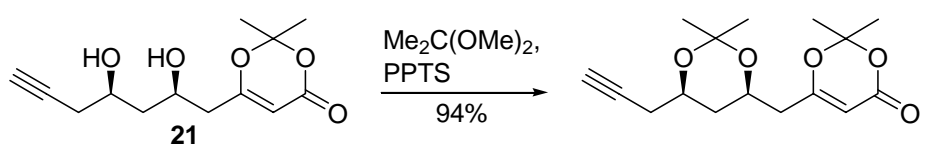

6-[(4R,6R)-2,2-Dimethyl-6-(2-propynyl)-1,3-dioxan-4-yl]methyl-2,2-dimethyl-1,3-dioxin-4-one

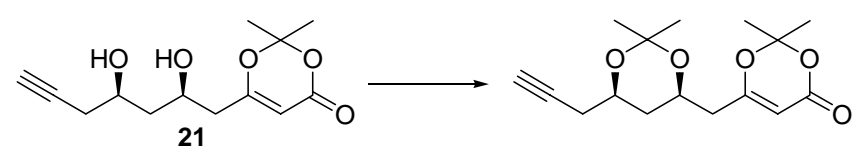

To a stirred solution of 21 (18.4 mg, $0.0724 \mathrm{mmol})$ in 2,2-dimethoxypropane (1 mL) was added PPTS $(0.7$ $\mathrm{mg}, 0.003 \mathrm{mmol})$. The mixture was stirred for $9 \mathrm{~h}$ and then $\mathrm{Et}_{3} \mathrm{~N}(0.05 \mathrm{~mL})$ was added. The mixture was concentrated in vacuo and the residue was purified by column chromatography on silica gel (EtOAc/hexane, $1: 3)$ to provide $20.1 \mathrm{mg}(94 \%)$ of the acetonide as a colorless oil; TLC, $\mathrm{R}_{f}($ EtOAc/hexane, $1: 1) ;[\alpha]_{\mathrm{D}}^{23}-46.5$ (c 1.01, $\left.\mathrm{CHCl}_{3}\right) ;{ }^{1} \mathrm{H}$ NMR $(270 \mathrm{MHz}) \delta 1.26(\mathrm{q}, J=12.2 \mathrm{~Hz}, 1 \mathrm{H}), 1.37,1.43,1.68,1.70(4 \mathrm{~s}, 3 \mathrm{H} \times 4), 1.80(\mathrm{dt}$, $J=12.2,2.4 \mathrm{~Hz}, 1 \mathrm{H}), 2.02(\mathrm{t}, J=2.6 \mathrm{~Hz}, 1 \mathrm{H}), 2.23-2.53(\mathrm{~m}, 4 \mathrm{H}), 4.00(\mathrm{~m}, 1 \mathrm{H}), 4.15(\mathrm{~m}, 1 \mathrm{H}), 5.32(\mathrm{~s}, 1 \mathrm{H})$; ${ }^{13} \mathrm{C}$ NMR $(68 \mathrm{MHz}) \delta 19.64,24.48,25.60,26.06,29.86,35.56,40.43,65.77,67.44,70.09,79.82,95.29$, 99.06, 106.49, 161.06, 168.23; IR (neat) 3000, 2950, 1735, $1635 \mathrm{~cm}^{-1}$; HRMS calcd for $\mathrm{C}_{16} \mathrm{H}_{22} \mathrm{O}_{5}\left(\mathrm{M}^{+}\right) \mathrm{m} / \mathrm{z}$ 294.1467, found 294.1487.

\footnotetext{
${ }^{7}$ Rychnovsky, S. D.; Rogers, B.; Yang, G. J. Org. Chem. 1993, 58, 3511-3515.
} 


\section{2. $\mathrm{C}(2)-\mathrm{C}(3)$ Geometry of TADA Substrates $\mathbf{1 6}$ and $\mathbf{4 9}$}

The $\mathrm{C}(2)-\mathrm{C}(3)$ geometry of $\mathbf{1 6}$ and $\mathbf{4 9}$ was determined to be $Z$ by NOE experiments as shown in Figure S1. In both cases, irradiation at $\mathrm{H}(2)$ enhanced one of two signals for $\mathrm{H}(17)$, establishing cis-relationship of $\mathrm{H}(2)-\mathrm{H}(17)$.

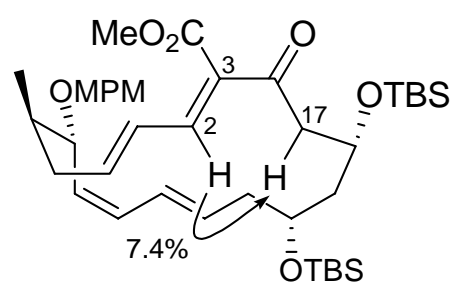

16

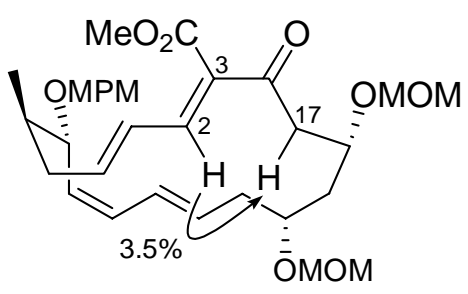

49

Figure S1. NOE experiments on TADA substrates 16 and 49. 


\subsection{Determination of the Stereochemistry of the Cycloadducts $40,10,11,44,50,51 a$, and $52 a$}

Stereochemistry of each cycloadduct was determined unambiguously by analysis of ${ }^{1} \mathrm{H}$ NMR spectrum and NOE difference experiments of the cycloadduct and its derivative if required. The syntheses of the derivatives are described in the Experimental Section (pages 22 and 39 for reduction of $\mathbf{4 0}$ and 52a, respectively).

Results of the NOE experiments on the cycloadducts produced via IMDA reactions are illustrated in Figure S2. The stereochemistry of $\mathbf{4 0}$, the cycloadduct obtained from model substrate 38, was determined as follows. The signal enhancement between substituents at angular positions established expected cis-anti-cis ring fusion. The $\pi$-facial selectivity of the reaction was determined by syn relationship $\mathrm{H}(7)$ and $\mathrm{H}(5)$. Likewise, stereochemistry of $\mathbf{1 0}$ and $\mathbf{1 1}$, cycloadducts with the same stereochemistry, was determined. On the other hand, NOE experiments revealed that $\mathbf{4 4}$ also have cis-anti-cis ring fusion, while it was established that the opposite $\pi$-facial selectivity provided $\mathbf{4 4}$ by syn relationship $\mathrm{H}(8)$ and $\mathrm{H}(9)$. These results indicate that all cycloadducts are derived from $(E, Z, E)-1,6,8$-nonatrienes. Thus alkene isomerization was not observed.

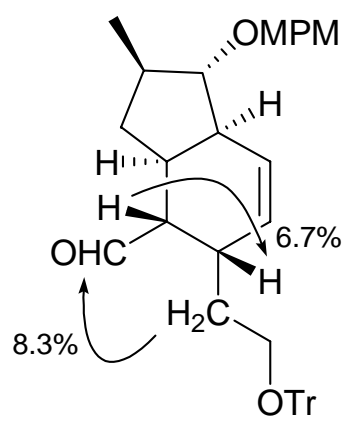

40

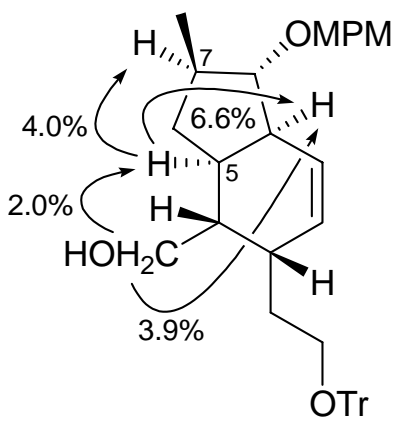

derived from $\mathbf{4 0}$ via $\mathrm{NaBH}_{4}$ reduction

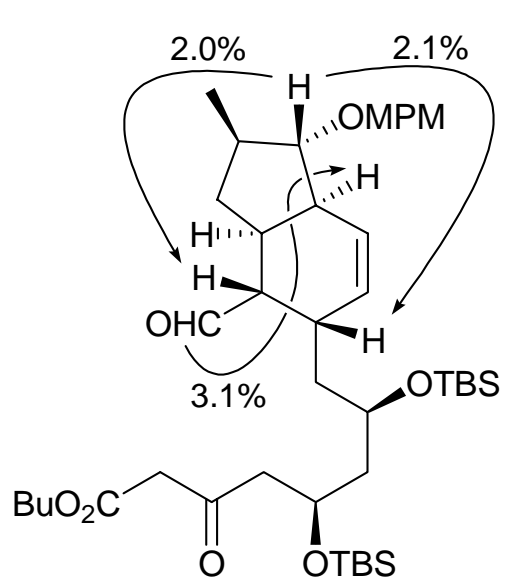

10

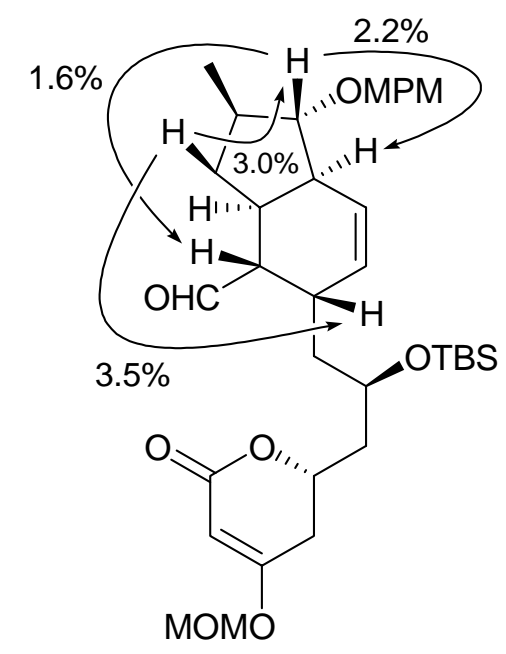

11

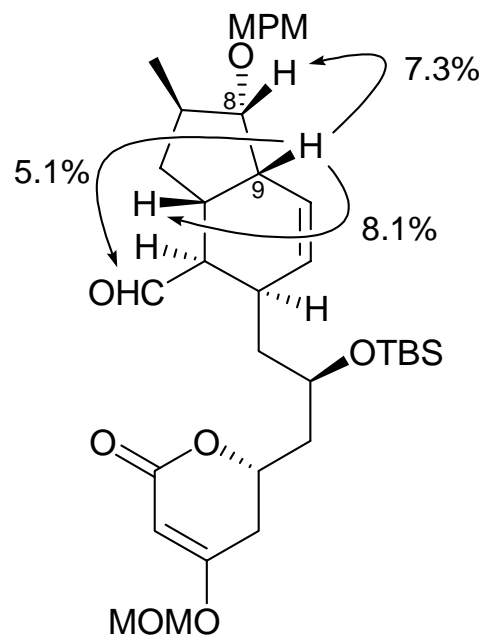

44

Figure S2. NOE experiments on the cycloadducts of the IMDA reactions 
The stereochemistry of cycloadducts 50, 51a, and 52a, obtained from TADA reactions of 16 and 49 are established as shown in Figure S3. The cycloadduct 50, afforded from 49, proved to have the same stereochemistry as macquarimicins. On the other hand, the NOE experiments on 51a revealed the opposite $\pi$-facial selectivity by syn relationship of $\mathrm{H}(8)$ and $\mathrm{H}(9)$. In the case of cycloadduct 52a, $\mathrm{C}(2)-\mathrm{C}(3)$ geometry was determined to be $E$, revealing involvement of alkene isomerization.
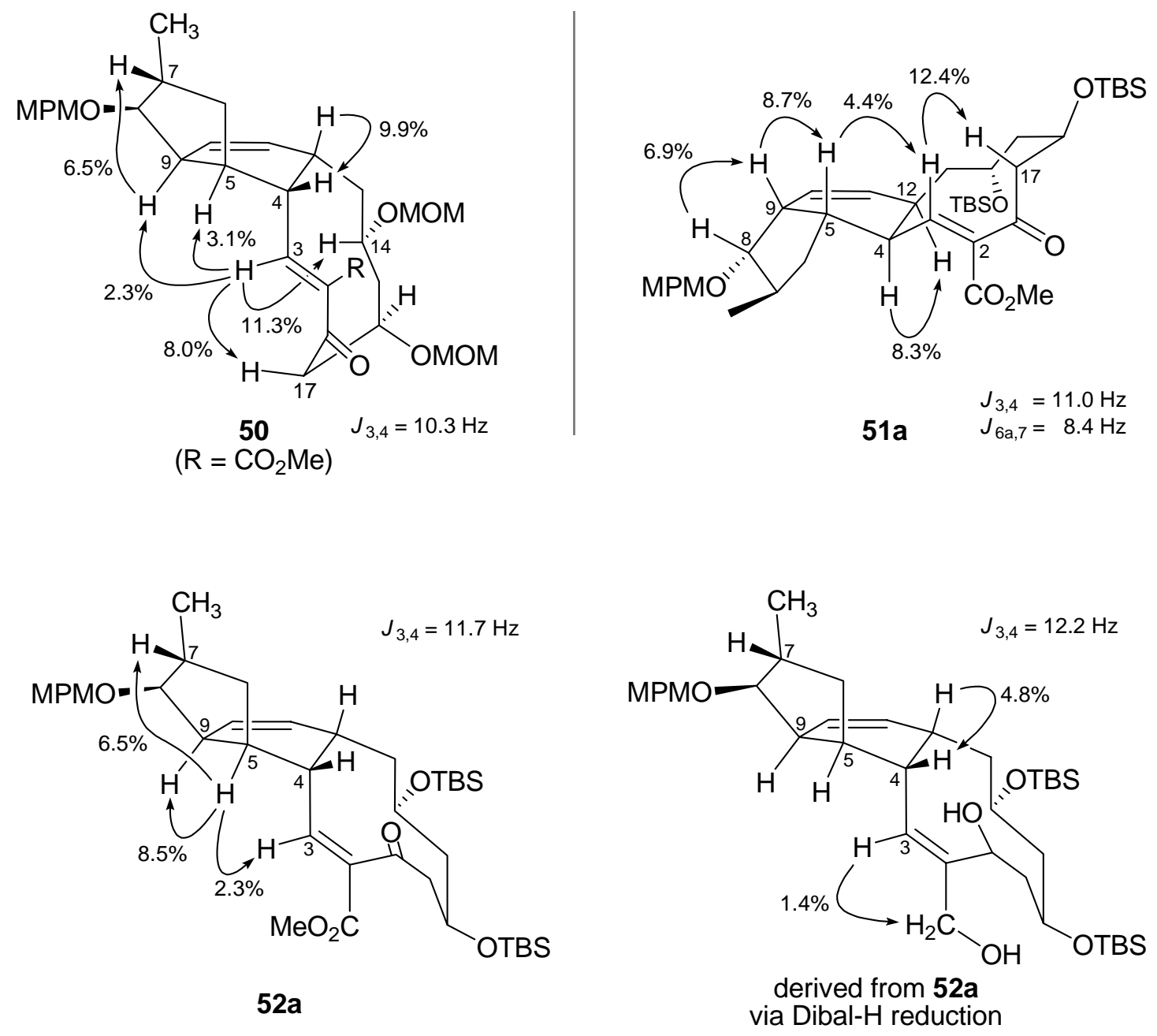

Figure S3. NOE experiments on the cycloadducts of the TADA reactions 